\title{
Data on Shallow Ground-Water Quality in the New Cassel Area, Long Island, New York, 1990-91, with Geophysical Logs of Selected Wells
}

By Richard A. Cartwright and Anthony Chu

U.S. GEOLOGICAL SURVEY

Open-File Report 96-104

Prepared in cooperation with the NASSAU COUNTY DEPARTMENT OF HEALTH 


\section{U.S. DEPARTMENT OF THE INTERIOR \\ BRUCE BABBITT, Secretary}

U.S. Geological Survey

Gordon P. Eaton, Director

For additional information write to:

U.S. Geological Survey 2045 Route 112, Bldg. 4 Coram, NY 11727
Copies of this report may be purchased from:

U.S. Geological Survey

Earth Science Information Center

Open-File Reports Section

P.O. Box 25286, MS 517

Denver Federal Center

Denver, CO 80225 


\section{CONTENTS}

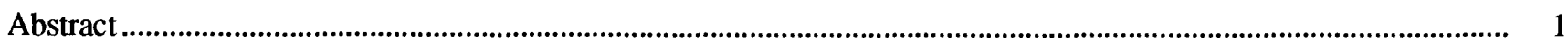

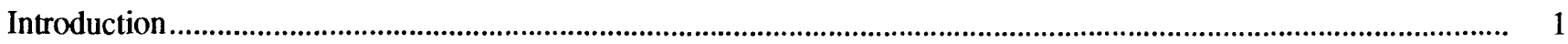

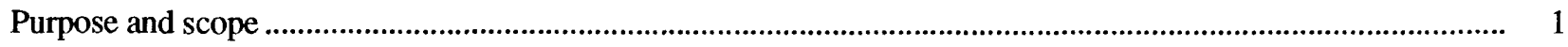

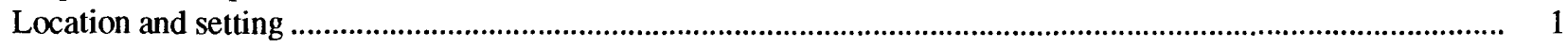

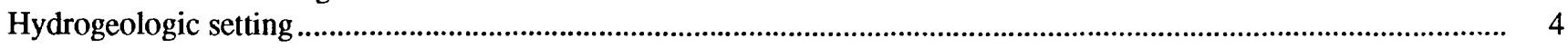

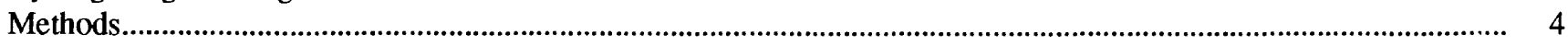

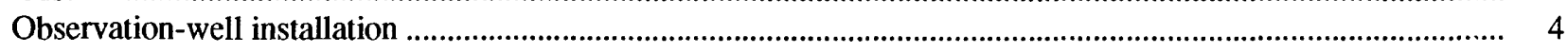

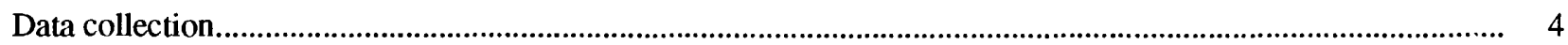

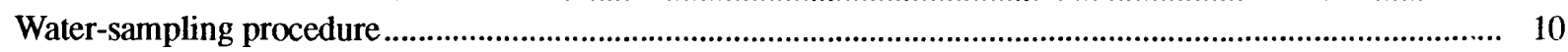

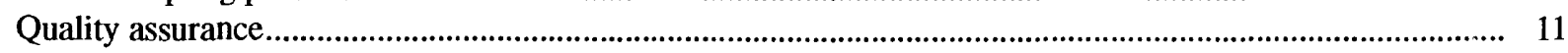

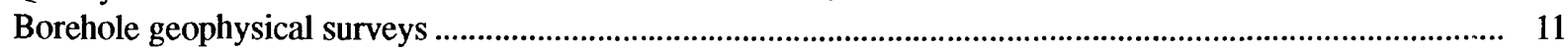

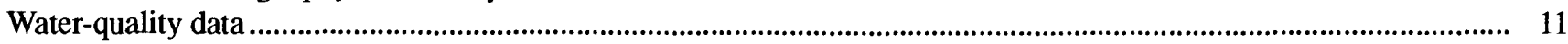

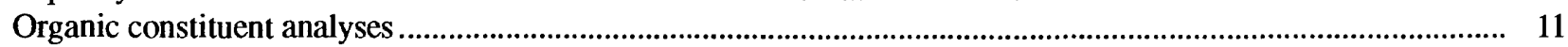

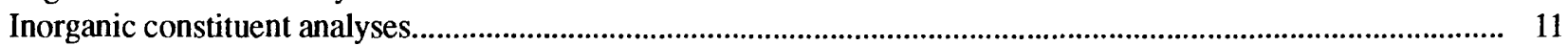

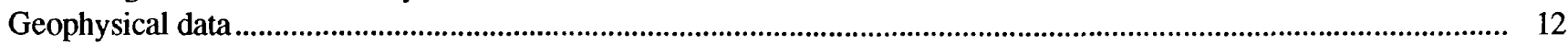

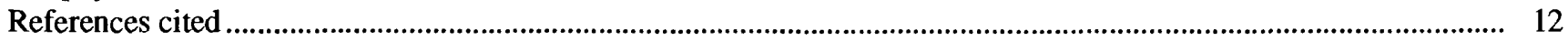

\section{FIGURES}

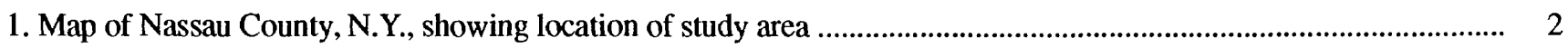

2. Map of Nassau County, N.Y., showing land use and observation-well locations in study area ................................. 3

3. Map of Nassau County, N.Y., showing observation-well locations with identifiers................................................ 5

4. Gamma and electromagnetic (EM)-induction logs from 21 selected newly installed wells in the study area, Nassa' County, N.Y.

\section{TABLES}

1. Well-completion data for selected wells near New Cassel, N.Y.

2. Water levels at selected wells near New Cassel, N.Y., 1990-91

3. Organic-constituent analyses of ground-water samples from the New Cassel, N.Y., study area, 1990-91

4. Inorganic-constituent analyses of ground-water samples from the New Cassel, N.Y., study area, 1990-91. 


\section{CONVERSION FACTORS, ABBREVIATIONS AND VERTICAL DATUM}

\begin{tabular}{|c|c|c|}
\hline Multiply & By & To Obtaln \\
\hline \multicolumn{3}{|c|}{ Length } \\
\hline foot $(\mathrm{ft})$ & 0.3048 & meter \\
\hline mile (mi) & 1.609 & kilometer \\
\hline \multicolumn{3}{|c|}{ Area } \\
\hline square mile $\left(\mathrm{mi}^{2}\right)$ & 2.59 & square kilometer \\
\hline \multicolumn{3}{|c|}{$\begin{array}{c}\text { Equivalent concentration terms } \\
\text { million }\end{array}$} \\
\hline micrograms per lite & L) equals & per billion (ppb) \\
\hline
\end{tabular}

Sea level: In this report, "sea level" refers to the National Geodetic Vertical Datum of 1929 (NGVD of 1929)-a geodetic datum derived from a general adjustment of the first-order level nets of the United States and Canada, formerly called Sea Level Datum of 1929. 


\title{
DATA ON SHALLOW GROUND-WATER QUALITY IN THE NEW CASSEL AREA, LONG ISLAND, NEW YORK, 1990-91, WITH GEOPHYSICAL LOGS OF SELECTED WELLS
}

\author{
By Richard A. Cartwright and Anthony Chu
}

\begin{abstract}
Areas of Nassau County with high population density and industrial/commercial activity have a high potential for ground-water contamination. Ground water in the New Cassel study area, a 4square-mile area in the towns of Hempstead and North Hempstead, was sampled from May 1990 through May 1991 to document concentrations of volatile organic and inorganic constituents.

This report presents the concentrations of organic and inorganic constituents detected in samples from 74 water-table wells and includes geophysical (gamma and electromagnetic) logs of 21 of the 22 wells that were newly installed for the study. It also presents ground-water levels at the time of sampling and well-completion data, and describes the field methods and quality-control procedures for water-sample collection.
\end{abstract}

\section{INTRODUCTION}

Ground water is the sole source of water supply in central and eastern Long Island; therefore its protection is a major concern for ground-water managers. Major parts of Nassau County have a high population density and contain scattered areas of intense industrial activity. Because the underlying glacial deposits are highly permeable, contaminants from land surface can move rapidly to the water table.

A preliminary investigation of several areas in Nassau County in which ground-water contamination was suspected was conducted in $1984-85$ by Dvirka and Bartilucci (1986). One of the areas investigated in that study was at New Cassel in the Town of North Hempstead (fig. 1), where high concentrations of sev- eral volatile organic compounds (VOC's) were detected in the water-table aquifer. In 1989, the U.S. Geological Survey (USGS), in cooperation with the Nassau County Department of Health (NCDH), conducted a follow-up study to further investigate the contamination problem. The study entailed collection of water-quality and geophysical data from 74 watertable observation wells, 22 of which were installed for the study.

\section{Purpose and Scope}

This report briefly describes the hydrogeologic setting in the study area, the methods of water-sample collection, and the quality-control procedures. It also presents (1) tables of well-completion data, heads in the water-table aquifer, and concentrations of selected organic and inorganic constituents at the time of sampling, and (2) gamma and electromagnetic logs of 21 of the 22 newly installed wells.

\section{Location and Setting}

The study area comprises about $4 \mathrm{mi}^{2}$ in the towns of Hempstead and North Hempstead in east-central Nassau County (fig. 1). The main sites of investigation are the industrial/commercial areas in the hamlet of New Cassel in the northern half of the study area, and the predominantly residential area to the south in the hamlet of Salisbury (fig. 2). These areas, hereafter referred to as the New Cassel study area, were developed in the late 1940's and early 1950's, and growth since then has been minimal. The 1991 populations in New Cassel and Salisbury were 10,327 and 12,226, respectively (Long Island Lighting Company, 1991). 

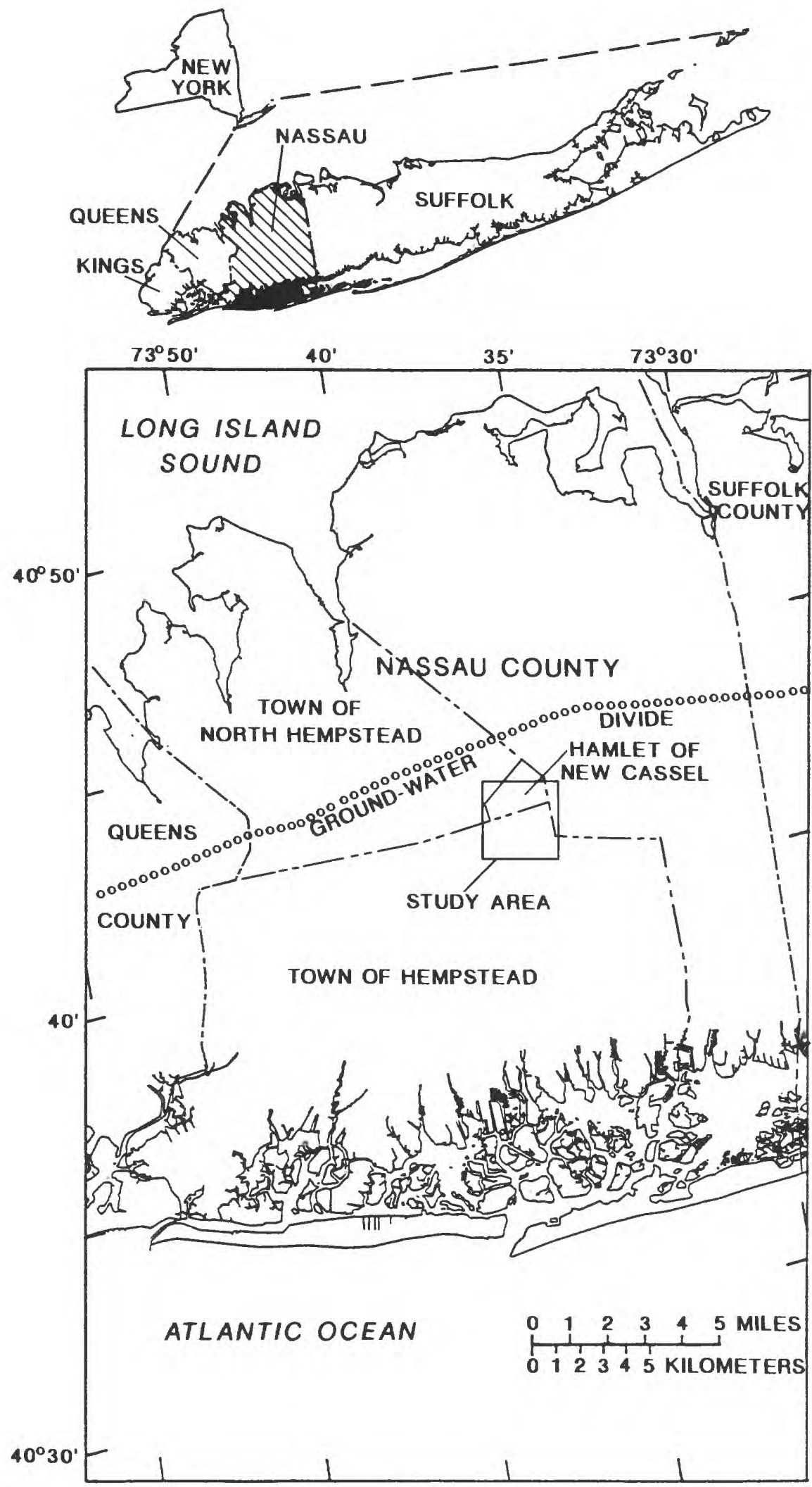

Figure 1. Location of study area in Nassau County, N.Y. 


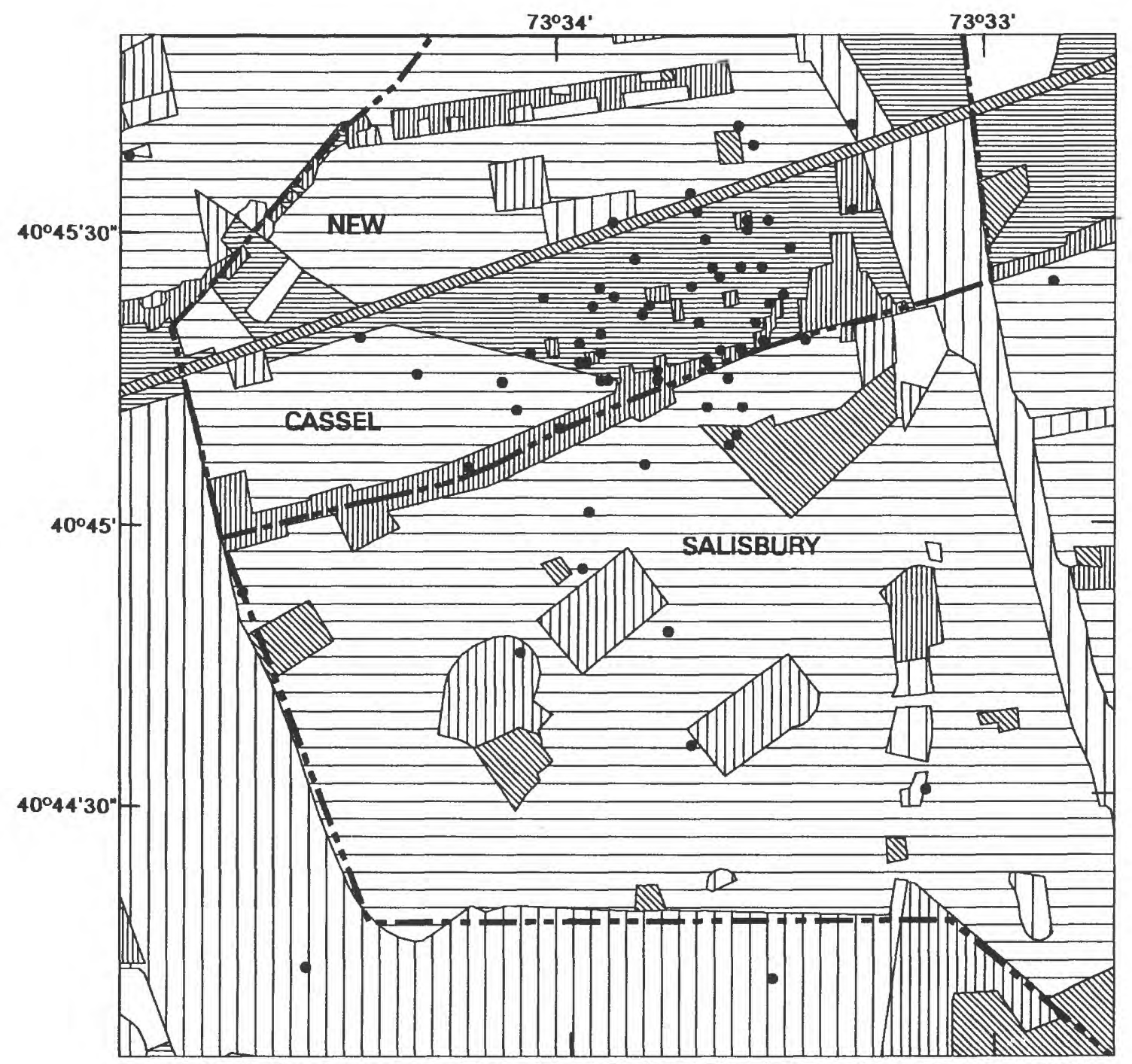

Base from digitized coverage of Long Island Regional Planning Board Land Use map 1981.

EXPLANATION

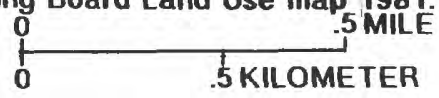

- Observation Well

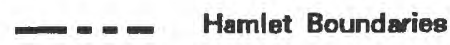

LAND USE

\begin{tabular}{|c|c|}
\hline & Residential \\
\hline . & Commercial \\
\hline E & Industrial \\
\hline & Institutional \\
\hline
\end{tabular}

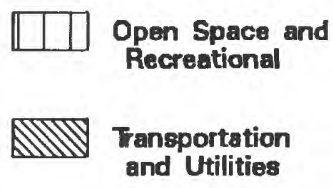

Vacant

Figure 2. Land use and observation-well locations in study area, Nassau County, N.Y. (Well numbers are shown in fig. 3. General location is shown in fig. 1.) 


\section{HYDROGEOLOGIC SETTING}

Long Island consists of a wedge-shaped mass of unconsolidated Cretaceous and Pleistocene deposits that overlie a bedrock surface that has a dip of less than 1 degree to the southeast (Franke and McClymonds, 1972). These sand, silt, clay, and gravel layers constitute the aquifers and confining units of Long Island's hydrogeologic system.

The New Cassel study area is south of Long Island's ground-water divide (fig. 1). The area is underlain by about $1,000 \mathrm{ft}$ of unconsolidated sediments (Smolensky and others, 1989). The surficial Pleistocene deposits, which are about $50 \mathrm{ft}$ thick, form the upper glacial aquifer. The upper glacial aquifer is underlain by the Magothy aquifer, which consists of about $520 \mathrm{ft}$ of Cretaceous sediments. The water table can be in either the upper glacial or the Magothy aquifer, and the aquifers are hydraulically connected. The Magothy aquifer is, in turn, underlain by older Cretaceous deposits that make up the Raritan Formation. The upper part of the Raritan is a clay confining unit about $180 \mathrm{ft}$ thick. The lower part of the Raritan is the Lloyd aquifer, which is about $270 \mathrm{ft}$ thick, and lies unconformably over PreCambrian bedrock.

\section{METHODS}

The study entailed measurement of water levels, and sampling and chemical analysis of water from wells screened in the water-table aquifer. The well network consisted of 74 wells (fig. 3), 22 of which were installed for this study. Borehole-geophysical surveys (natural gamma and electromagnetic) were conducted at 21 of the new wells to define hydrogeologic boundaries and zones for well-screen placement.

\section{Observation-Well Installation}

Observation wells were installed to enhance the coverage provided by older wells to help define the extent of shallow ground-water contamination by synthetic organic compounds (fig. 3). These wells were installed from November 29 through December 7, 1990 by a USGS auger rig with 6-in. hollow-stem augers. Nineteen wells are screened at the bottom of the watertable aquifer; the screened zones range from 50 to $60 \mathrm{ft}$ below land surface. Three wells are screened in the upper part of the Magothy aquifer at depths ranging from 90 to $100 \mathrm{ft}$ below land surface. Selection of screen depths of the new wells was based on waterquality analyses from the 52 older wells.

All wells are cased with 2-in. PVC (polyvinyl chloride) pipe with flush-threaded joints. Five-foot PVC slotted screens with 5-ft sumps were used. No glues were used in well construction. Well-completion data from selected wells are listed in table 1; the corresponding water-levels measured in 1990-91 are listed in table 2.

When each well had been augered to the desired depth, the casing was assembled and lowered through the center of the auger flights until it came into contact with a steel plug at the bottom of the bit. The purpose of the plug was to keep the sediment-and-water mixture out of the drill stem during augering. Before the plug was knocked out, water was added to the annular space between the inside of the auger stem and the outside of the PVC casing until it was about half full. This head of water prevented an upward rush of sediment and water between the casing and the auger stem when the plug was knocked out, to minimize the possibility of a "sand lock" (the casing gets "locked" inside of the auger stem). The water used for this purpose was analyzed qualitatively on the USGS gas chromatograph flameionization detector and was determined to be free of VOC's. After the plug was knocked out, the auger flights were removed, and the annular space between the hole and the casing was backfilled with loose sand cuttings from the unsaturated zone. This sand had been exposed to air and had been moderately mixed by shoveling and, consequently, was assumed to add no synthetic organic compounds to the well.

Two to four wells per day were installed in this manner. After installation of each well, the bit and augers were washed inside and out with clean water to remove all aquifer material and thereby minimize crosscontamination between wells.

\section{Data Collection}

The study contained two sampling periods-one in 1990 and one in 1991. A set of 52 wells, 35 of which were installed by NCDH for the Dvirka and Bartilucci (1986) study and 17 that were older monitoring wells, were sampled for chemical analysis from May through August 1990. Results of these analyses were compared with the well locations and approximate direction of ground-water flow to determine 


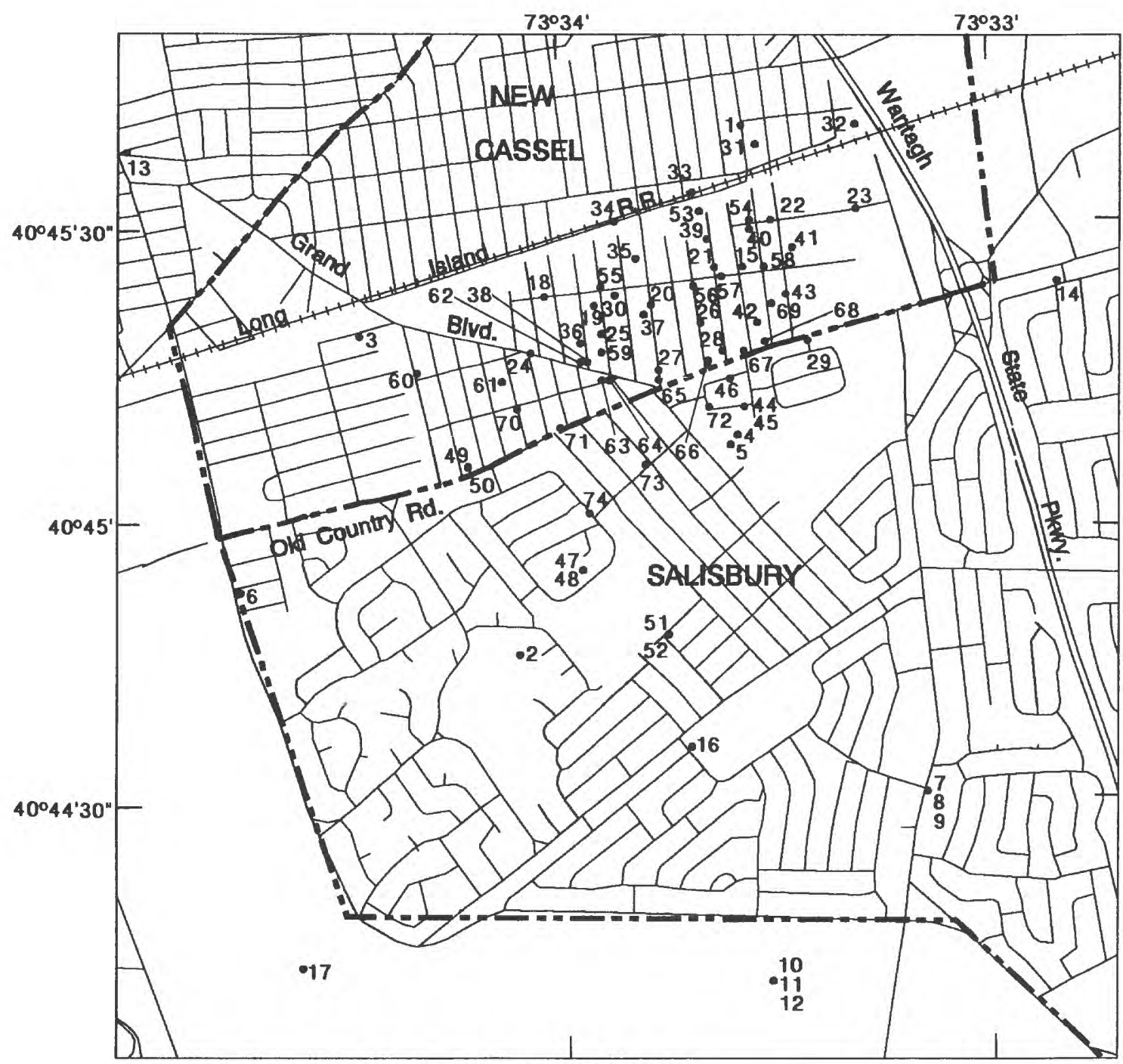

Base from digitized coverage of 1:24,000 scale maps. EXPLANATION

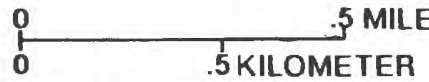

- Observation Well and identification Number; Two or more numbers indicates multiple wells at site

$-\quad$ Hamlet Boundary

Well Identifiers with Well Numbers (prefix $\mathrm{N}$ indicates Nassau County)

$\begin{array}{ll}1 & \text { N5655 } \\ 2 & \text { N6848 } \\ 3 & N 8497 \\ 4 & N 8956 \\ 5 & N 8957 \\ 6 & N 8984 \\ 7 & N 9234 \\ 8 & N 9235 \\ 9 & N 9236 \\ 10 & N 9239 \\ 11 & N 9240 \\ 12 & N 9241 \\ 13 & \text { N9354 } \\ 14 & \text { N9917 } \\ 15 & \text { N9938 }\end{array}$

$\begin{array}{ll}16 & N 9939 \\ 17 & N 10292 \\ 18 & N 10318 \\ 19 & N 10319 \\ 20 & N 10320 \\ 21 & N 10321 \\ 22 & N 10322 \\ 23 & N 10323 \\ 24 & N 10324 \\ 25 & N 10325 \\ 26 & N 10326 \\ 27 & N 10327 \\ 28 & N 10328 \\ 29 & N 10329 \\ 30 & N 10458\end{array}$

$\begin{array}{ll}31 & N 10459 \\ 32 & N 10460 \\ 33 & N 10461 \\ 34 & N 10462 \\ 35 & N 10463 \\ 36 & N 10464 \\ 37 & N 10465 \\ 38 & N 10466 \\ 39 & N 10467 \\ 40 & N 10468 \\ 41 & N 10469 \\ 42 & N 10470 \\ 43 & N 10471 \\ 44 & N 10472 \\ 45 & N 10473\end{array}$

$\begin{array}{ll}46 & N 10474 \\ 47 & N 10475 \\ 48 & N 10476 \\ 49 & N 10477 \\ 50 & N 10478 \\ 51 & N 10479 \\ 52 & N 10480 \\ 53 & N 11841 \\ 54 & N 11842 \\ 55 & N 11843 \\ 56 & N 11844 \\ 57 & N 11845 \\ 58 & N 11846 \\ 59 & N 11847 \\ 60 & N 11848\end{array}$

$\begin{array}{ll}61 & N 11849 \\ 62 & N 11850 \\ 63 & N 11851 \\ 64 & N 11852 \\ 65 & N 11853 \\ 66 & N 11854 \\ 67 & N 11855 \\ 68 & N 11856 \\ 69 & N 11857 \\ 70 & N 11858 \\ 71 & N 11859 \\ 72 & N 11860 \\ 73 & N 11861 \\ 74 & N 11862\end{array}$

Figure 3. Locations of observation wells with identifiers, Nassau County, N.Y. (General location is shown in fig. 1.) 
Table 1. Well-completion data for selected wells near New Cassel, N.Y.

[LSD, land surface datum; MGTY, Magothy aquifer; UPG, upper glacial aquifer. Locations are shown in fig. 3]

\begin{tabular}{|c|c|c|c|c|c|c|c|c|}
\hline \multirow{2}{*}{$\begin{array}{c}\text { Well } \\
\text { number }\end{array}$} & \multirow[b]{2}{*}{ Latitude } & \multirow[b]{2}{*}{ Longitude } & \multirow{2}{*}{$\begin{array}{c}\text { Approximate } \\
\text { LSD } \\
\text { (feet above } \\
\text { sea level) }\end{array}$} & \multirow{2}{*}{$\begin{array}{c}\text { Depth } \\
\text { (feet } \\
\text { below } \\
\text { LSD) }\end{array}$} & \multicolumn{2}{|c|}{$\begin{array}{l}\text { Screened } \\
\text { Interval } \\
\text { (feet below } \\
\text { LSD) }\end{array}$} & \multirow[b]{2}{*}{ Aquifer } & \multirow[b]{2}{*}{ Well use } \\
\hline & & & & & Top & Bottom & & \\
\hline N5655 & 404541 & 733335 & 130 & 260 & 205 & 255 & MGTY & Unspecified withdrawal \\
\hline N6848 & 404445 & 733407 & 106 & 104 & 93 & 104 & MGTY & Observation \\
\hline N8497 & 404519 & 733429 & 115 & 544 & 456 & 539 & MGTY & Unspecified withdrawal \\
\hline N8956 & 404508 & 733336 & 115 & 535 & 470 & 530 & MGTY & Public supply \\
\hline N8957 & 404507 & 733337 & 115 & 589 & 524 & 584 & MGTY & Public supply \\
\hline N8984 & 404452 & 733446 & 104 & 52 & 47 & 52 & UPG & Observation \\
\hline N9234 & 404430 & 733310 & 107 & 206 & 200 & 205 & MGTY & Observation \\
\hline N9235 & 404430 & 733310 & 107 & 106 & 100 & 105 & MGTY & Observation \\
\hline N9236 & 404430 & 733310 & 107 & 51 & 45 & 50 & UPG & Observation \\
\hline N9239 & 404410 & 733337 & 101 & 206 & 200 & 205 & MGTY & Observation \\
\hline N9240 & 404410 & 733332 & 101 & 106 & 100 & 105 & MGTY & Observation \\
\hline N9241 & 404410 & 733332 & 101 & 46 & 40 & 45 & UPG & Observation \\
\hline N9354 & 404539 & 733501 & 118 & 89 & 84 & 89 & UPG & Observation \\
\hline N9917 & 404524 & 733251 & 125 & 76 & 68 & 73 & UPG & Observation \\
\hline N9938 & 404526 & 733335 & 125 & 80 & 72 & 77 & UPG & Observation \\
\hline N9939 & 404435 & 733343 & 106 & 74 & 66 & 71 & UPG & Observation \\
\hline N10292 & 404412 & 733438 & 78 & 50 & 45 & 50 & UPG & Observation \\
\hline N10318 & 404523 & 733403 & 120 & 60 & 50 & 60 & UPG & Observation \\
\hline N10319 & 404522 & 733356 & 122 & 57 & 47 & 57 & UPG & Observation \\
\hline N10320 & 404522 & 733348 & 123 & 60 & 50 & 60 & UPG & Observation \\
\hline N10321 & 404526 & 733339 & 124 & 62 & 52 & 62 & UPG & Observation \\
\hline N10322 & 404531 & 733331 & 127 & 67 & 57 & 67 & UPG & Observation \\
\hline N10323 & 404532 & 733319 & 127 & 62 & 52 & 62 & UPG & Observation \\
\hline $\mathrm{N} 10324$ & 404517 & 733405 & 118 & 57 & 47 & 57 & UPG & Observation \\
\hline N10325 & 404519 & 733355 & 119 & 57 & 47 & 57 & UPG & Observation \\
\hline N10326 & 404520 & 733341 & 122 & 59 & 49 & 59 & UPG & Observation \\
\hline N10327 & 404515 & 733347 & 120 & 58 & 48 & 58 & UPG & Observation \\
\hline N10328 & 404517 & 733338 & 119 & 58 & 48 & 58 & UPG & Observation \\
\hline N10329 & 404518 & 733326 & 124 & 57 & 47 & 57 & UPG & Observation \\
\hline N10458 & 404523 & 733353 & 122 & 120 & 100 & 120 & MGTY & Observation \\
\hline N10459 & 404539 & 733333 & 130 & 68 & 58 & 68 & UPG & Observation \\
\hline N10460 & 404541 & 733319 & 131 & 68 & 58 & 68 & UPG & Observation \\
\hline N10461 & 404534 & 733342 & 126 & 66 & 56 & 66 & UPG & Observation \\
\hline N10462 & 404531 & 733353 & 124 & 64 & 54 & 64 & UPG & Observation \\
\hline N10463 & 404527 & 733350 & 123 & 64 & 54 & 64 & UPG & Observation \\
\hline N10464 & 404518 & 733358 & 118 & 60 & 50 & 60 & UPG & Observation \\
\hline N10465 & 404521 & 733349 & 121 & 62 & 52 & 62 & UPG & Observation \\
\hline N10466 & 404516 & 733357 & 118 & 60 & 50 & 60 & UPG & Observation \\
\hline N10467 & 404529 & 733340 & 126 & 63 & 53 & 63 & UPG & Observation \\
\hline
\end{tabular}


Table 1. Well-completion data for selected wells near New Cassel, N.Y.-continued

\begin{tabular}{|c|c|c|c|c|c|c|c|c|}
\hline \multirow{2}{*}{$\begin{array}{c}\text { Weli } \\
\text { number }\end{array}$} & \multirow[b]{2}{*}{ Latitude } & \multirow[b]{2}{*}{ Longltude } & \multirow{2}{*}{$\begin{array}{c}\text { Approximate } \\
\text { land-surface } \\
\text { datum } \\
\text { (feet above } \\
\text { sea level) }\end{array}$} & \multirow{2}{*}{$\begin{array}{l}\text { Depth } \\
\text { (feet } \\
\text { below } \\
\text { LSD) }\end{array}$} & \multicolumn{2}{|c|}{$\begin{array}{l}\text { Screened } \\
\text { Interval } \\
\text { (feet below } \\
\text { LSD) }\end{array}$} & \multirow[b]{2}{*}{ Aquifer } & \multirow[b]{2}{*}{ Well use } \\
\hline & & & & & Top & Bottom & & \\
\hline N10468 & 404530 & 733334 & 125 & 125 & 105 & 125 & MGTY & Observation \\
\hline N10469 & 404528 & 733328 & 123 & 64 & 54 & 64 & UPG & Observation \\
\hline N10470 & 404520 & 733333 & 120 & 65 & 55 & 65 & UPG & Observation \\
\hline N10471 & 404523 & 733329 & 119 & 60 & 50 & 60 & UPG & Observation \\
\hline N10472 & 404511 & 733335 & 113 & 62 & 52 & 62 & UPG & Observation \\
\hline N10473 & 404511 & 733335 & 112 & 120 & 100 & 120 & MGTY & Observation \\
\hline N10474 & 404514 & 733337 & 117 & 60 & 50 & 60 & UPG & Observation \\
\hline N10475 & 404454 & 733358 & 111 & 57 & 47 & 57 & UPG & Observation \\
\hline N10476 & 404454 & 733358 & 111 & 130 & 110 & 130 & MGTY & Observation \\
\hline N10477 & 404505 & 733414 & 112 & 57 & 47 & 57 & UPG & Observation \\
\hline N10478 & 404505 & 733414 & 112 & 121 & 101 & 121 & MGTY & Observation \\
\hline N10479 & 404447 & 733346 & 94 & 40 & 30 & 40 & UPG & Observation \\
\hline N10480 & 404447 & 733346 & 94 & 118 & 98 & 118 & MGTY & Observation \\
\hline N11841 & 404543 & 733341 & 127 & 65 & 55 & 60 & UPG & Observation \\
\hline N11842 & 404531 & 733334 & 127 & 65 & 55 & 60 & UPG & Observation \\
\hline N11843 & 404524 & 733355 & 122 & 60 & 50 & 55 & UPG & Observation \\
\hline N11844 & 404524 & 733342 & 124 & 65 & 55 & 60 & UPG & Observation \\
\hline N11845 & 404525 & 733338 & 124 & 65 & 55 & 60 & UPG & Observation \\
\hline N11846 & 404526 & 733332 & 124 & 65 & 55 & 60 & UPG & Observation \\
\hline N11847 & 404517 & 733355 & 120 & 100 & 90 & 95 & MGTY & Observation \\
\hline N11848 & 404515 & 733421 & 110 & 60 & 50 & 55 & UPG & Observation \\
\hline N11849 & 404514 & 733409 & 116 & 60 & 50 & 55 & UPG & Observation \\
\hline N11850 & 404515 & 733358 & 119 & 65 & 55 & 60 & UPG & Observation \\
\hline N11851 & 404514 & 733355 & 119 & 65 & 55 & 60 & UPG & Observation \\
\hline N11852 & 404514 & 733354 & 119 & 100 & 90 & 95 & MGTY & Observation \\
\hline N11853 & 404514 & 733347 & 119 & 60 & 50 & 55 & UPG & Observation \\
\hline N11854 & 404516 & 733340 & 120 & 60 & 50 & 55 & UPG & Observation \\
\hline N11855 & 404517 & 733335 & 118 & 60 & 50 & 55 & UPG & Observation \\
\hline N11856 & 404518 & 733332 & 120 & 60 & 50 & 55 & UPG & Observation \\
\hline N11857 & 404522 & 733331 & 120 & 105 & 95 & 100 & MGTY & Observation \\
\hline N11858 & 404511 & 733407 & 114 & 60 & 50 & 55 & UPG & Observation \\
\hline N11859 & 404509 & 733401 & 116 & 60 & 50 & 55 & UPG & Observation \\
\hline N11860 & 404511 & 733340 & 116 & 60 & 50 & 55 & UPG & Observation \\
\hline N11861 & 404505 & 733349 & 115 & 60 & 50 & 55 & UPG & Observation \\
\hline N11862 & 404500 & 733357 & 112 & 60 & 50 & 55 & UPG & Observation \\
\hline
\end{tabular}


Table 2. Water levels at selected wells near New Cassel, N.Y., 1990-91

[Water levels are in feet above sea level. Well locations shown in fig. 3]

\begin{tabular}{|c|c|c|c|c|c|c|c|c|}
\hline $\begin{array}{c}\text { Well } \\
\text { number }\end{array}$ & Date & $\begin{array}{l}\text { Water } \\
\text { level }\end{array}$ & $\begin{array}{c}\text { Well } \\
\text { number }\end{array}$ & Date & $\begin{array}{l}\text { Water } \\
\text { level }\end{array}$ & $\begin{array}{c}\text { Well } \\
\text { number }\end{array}$ & Date & $\begin{array}{l}\text { Water } \\
\text { level }\end{array}$ \\
\hline \multirow[t]{11}{*}{ N8984 } & $1-16-90$ & $\overline{70.64}$ & N9240 & $1-18-90$ & 64.25 & N9938 & $3-22-91$ & 76.81 \\
\hline & $2-12-90$ & 70.67 & & $2-12-90$ & 63.91 & & $8-26-91$ & 76.05 \\
\hline & $3-26-90$ & 70.32 & & $3-28-90$ & 63.70 & & $10-23-91$ & 75.76 \\
\hline & $4-25-90$ & 70.83 & & $5-17-90$ & 64.43 & & & \\
\hline & $6-4-90$ & 73.16 & & $8-16-90$ & 64.61 & N9939 & $1-16-90$ & 68.13 \\
\hline & $6-19-90$ & 72.81 & & $8-17-90$ & 64.58 & & $2-12-91)$ & 67.91 \\
\hline & $8-15-90$ & 71.70 & & $10-22-90$ & 64.19 & & $3-27-97$ & 67.62 \\
\hline & $10-31-90$ & 72.47 & & $1-10-91$ & 64.43 & & 4-18-91 & 67.76 \\
\hline & $11-5-90$ & 72.50 & & $1-29-91$ & 65.01 & & $6-19-91$ & 69.73 \\
\hline & $8-27-91$ & 71.91 & & $3-19-91$ & 65.11 & & $8-15-9)$ & 68.65 \\
\hline & & & & $4-25-91$ & 64.96 & & $10-31-97$ & 68.80 \\
\hline \multirow[t]{6}{*}{ N9234 } & $8-17-90$ & 67.95 & & $11-27-91$ & 62.71 & & $1-10-91$ & 68.59 \\
\hline & $10-31-90$ & 68.25 & & & & & $3-21-91$ & 69.08 \\
\hline & $3-21-91$ & 68.49 & N9241 & $1-18-90$ & 64.31 & & $6-28-91$ & 68.45 \\
\hline & $6-28-91$ & 67.93 & & $2-12-90$ & 63.97 & & $7-25-91$ & 67.86 \\
\hline & $10-23-91$ & 66.99 & & $3-28-90$ & 63.75 & & $8-27-91$ & 67.93 \\
\hline & & & & $5-17-90$ & 64.45 & & $10-23-91$ & 67.48 \\
\hline \multirow[t]{6}{*}{ N9235 } & $8-17-90$ & 68.23 & & $8-16-90$ & 64.66 & & & \\
\hline & $10-31-90$ & 68.35 & & $8-17-90$ & 64.64 & N10292 & $1-16-97$ & 63.38 \\
\hline & $3-21-91$ & 68.58 & & $8-20-90$ & 64.58 & & $2-12-97$ & 63.28 \\
\hline & $6-28-91$ & 68.14 & & $10-22-90$ & 64.23 & & $3-26-97$ & 62.87 \\
\hline & $10-23-91$ & 67.05 & & $1-10-91$ & 64.46 & & 6-18-9) & 64.58 \\
\hline & & & & $2-19-91$ & 65.27 & & 6-19-9) & 64.61 \\
\hline \multirow[t]{8}{*}{ N9236 } & $4-20-90$ & 67.37 & & $3-19-91$ & 65.15 & & $7-18-97$ & 63.94 \\
\hline & $7-18-90$ & 68.87 & & $4-25-91$ & 65.02 & & $8-15-9)$ & 63.64 \\
\hline & $8-17-90$ & 68.34 & & $5-21-91$ & 64.93 & & $10-31-97$ & 64.05 \\
\hline & $10-31-90$ & 68.36 & & $6-24-91$ & 64.63 & & $12-11-9)$ & 63.73 \\
\hline & $3-21-91$ & 68.60 & & $8-1-91$ & 63.83 & & $1-10-91$ & 63.45 \\
\hline & $6-28-91$ & 68.19 & & $9-5-91$ & 63.79 & & $2-21-91$ & 63.91 \\
\hline & $10-23-91$ & 67.04 & & $10-22-91$ & 63.25 & & $3-21-91$ & 64.13 \\
\hline & & & & $11-27-91$ & 62.76 & & 4-26-91 & 64.16 \\
\hline \multirow[t]{17}{*}{ N9239 } & $1-18-90$ & 63.98 & & & & & $5-21-91$ & 64.11 \\
\hline & $2-12-90$ & 63.72 & N9354 & $4-25-90$ & 73.58 & & $6-25-91$ & 63.45 \\
\hline & $3-28-90$ & 63.47 & & $11-5-90$ & 75.14 & & $8-6-91$ & 62.44 \\
\hline & $5-17-90$ & 64.37 & & $8-27-91$ & 74.67 & & $9-5-91$ & 62.57 \\
\hline & $8-16-90$ & 64.32 & & & & & $9-13-91$ & 62.38 \\
\hline & $8-17-90$ & 64.28 & N9917 & $3-26-90$ & 74.87 & & $10-22-91$ & 61.99 \\
\hline & $10-22-90$ & 64.05 & & $7-17-90$ & 76.75 & & $11-21-91$ & 61.56 \\
\hline & $1-10-91$ & 64.25 & & $11-5-90$ & 76.92 & & & \\
\hline & $2-19-91$ & 64.93 & & $8-27-91$ & 76.52 & N10318 & $5-1-97$ & 73.72 \\
\hline & $3-18-91$ & 64.90 & & & & & $6-7-97$ & 74.72 \\
\hline & $4-25-91$ & 64.77 & N9938 & $1-16-90$ & 75.21 & & $11-5-97$ & 74.94 \\
\hline & $5-21-91$ & 64.64 & & $2-12-90$ & 75.26 & & $8-26-91$ & 74.11 \\
\hline & $6-24-91$ & 64.31 & & $3-27-90$ & 74.82 & & & \\
\hline & $8-1-91$ & 63.46 & & $6-13-90$ & 76.47 & N10319 & $5-1-97$ & 73.89 \\
\hline & $9-5-91$ & 63.51 & & $6-19-90$ & 76.70 & & $6-18-97$ & 75.17 \\
\hline & $10-22-91$ & 63.01 & & $8-15-90$ & 76.19 & & $11-5-97$ & 75.12 \\
\hline & $11-27-91$ & 62.51 & & $10-31-90$ & 76.63 & & $8-26-91$ & 74.25 \\
\hline
\end{tabular}


Table 2. Water levels at selected wells near New Cassel, N.Y., 1990-91--continued

\begin{tabular}{|c|c|c|c|c|c|c|c|c|}
\hline $\begin{array}{c}\text { Well } \\
\text { number }\end{array}$ & Date & $\begin{array}{l}\text { Water } \\
\text { level }\end{array}$ & $\begin{array}{c}\text { Well } \\
\text { number }\end{array}$ & Date & $\begin{array}{l}\text { Water } \\
\text { level }\end{array}$ & $\begin{array}{c}\text { Well } \\
\text { number }\end{array}$ & Date & $\begin{array}{l}\text { Water } \\
\text { leve' }\end{array}$ \\
\hline \multirow[t]{4}{*}{ N10320 } & $5-1-90$ & $\overline{74.40}$ & N10458 & $5-2-90$ & $\overline{74.00}$ & N10468 & $5-1-90$ & $\overline{75.54}$ \\
\hline & $6-12-90$ & 75.59 & & $6-18-90$ & 75.22 & & $7-19-90$ & 76.81 \\
\hline & $11-5-90$ & 75.65 & & $11-5-90$ & 75.19 & & $11-5-90$ & 76.96 \\
\hline & $8-26-91$ & 74.55 & & $8-26-91$ & 74.30 & & $8-26-91$ & 76.27 \\
\hline \multirow[t]{5}{*}{ N10321 } & $5-1-90$ & 75.14 & N10459 & $5-2-90$ & 76.47 & N10469 & $5-1-90$ & 75.51 \\
\hline & $6-13-90$ & 76.42 & & $7-25-90$ & 77.89 & & $6-14-90$ & 76.86 \\
\hline & $11-5-90$ & 76.57 & & $8-26-91$ & 77.48 & & $11-5-90$ & 77.04 \\
\hline & $8-26-91$ & 75.82 & & & & & $8-26-91$ & 76.44 \\
\hline & & & N10460 & $5-1-90$ & 77.07 & & & \\
\hline \multirow[t]{4}{*}{ N10322 } & $5-1-90$ & 75.85 & & $6-5-90$ & 78.23 & N10470 & $5-1-90$ & 74.54 \\
\hline & $11-5-90$ & 77.59 & & $11-5-90$ & 78.75 & & $6-20-90$ & 75.89 \\
\hline & $8-26-91$ & 76.75 & & $8-26-91$ & 78.38 & & $7-17-90$ & 75.65 \\
\hline & & & & & & & $11-5-90$ & 76.01 \\
\hline \multirow[t]{5}{*}{ N10323 } & $5-2-90$ & 76.36 & N10461 & $5-2-90$ & 75.69 & & $8-26-91$ & 75.28 \\
\hline & $6-20-90$ & 77.77 & & $6-5-90$ & 76.75 & & & \\
\hline & $11-5-90$ & 77.99 & & $11-5-90$ & 77.12 & N10471 & $5-1-90$ & 74.93 \\
\hline & $8-26-91$ & 77.53 & & $8-26-91$ & 76.41 & & $6-20-90$ & 76.28 \\
\hline & & & & & & & $11-5-90$ & 76.46 \\
\hline \multirow[t]{4}{*}{ N10324 } & $5-1-90$ & 73.23 & N10462 & $5-1-90$ & 75.01 & & $8-26-91$ & 75.78 \\
\hline & $6-7-90$ & 74.31 & & $6-5-90$ & 75.96 & & & \\
\hline & $11-5-90$ & 74.42 & & $11-5-90$ & 76.29 & N10472 & $5-2-90$ & 73.49 \\
\hline & $8-26-91$ & 73.44 & & $8-26-91$ & 75.54 & & $5-30-90$ & 75.50 \\
\hline \multirow[t]{5}{*}{$\mathrm{N} 10325$} & $5-1-90$ & 73.24 & N10463 & $5-1-90$ & 74.47 & N10473 & $5-2-90$ & 73.47 \\
\hline & $6-7-90$ & 74.48 & & $6-13-90$ & 75.64 & & $5-30-90$ & 75.57 \\
\hline & $11-5-90$ & 74.47 & & $11-5-90$ & 75.69 & & & \\
\hline & $8-26-91$ & 73.55 & & $8-26-91$ & 74.88 & N10474 & $5-2-90$ & 74.79 \\
\hline & & & & & & & $6-1-90$ & 76.31 \\
\hline \multirow[t]{5}{*}{ N10326 } & $5-1-90$ & 72.04 & N10464 & $5-1-90$ & 73.26 & & $8-26-90$ & 75.51 \\
\hline & $6-18-90$ & 73.43 & & $6-7-90$ & 7435 & & $9-9-91$ & 74.91 \\
\hline & $11-5-90$ & 73.43 & & $11-5-90$ & 74.43 & & & \\
\hline & $8-26-91$ & 72.58 & & $8-26-91$ & 73.45 & N10475 & $5-2-90$ & 74.77 \\
\hline & & & & & & & $5-8-90$ & 74.72 \\
\hline \multirow[t]{5}{*}{ N10327 } & $5-1-90$ & 73.59 & N10465 & $5-1-90$ & 73.85 & & $5-22-90$ & 76.22 \\
\hline & $6-12-90$ & 74.93 & & $6-12-90$ & 75.07 & & $6-1-90$ & 76.25 \\
\hline & $11-5-90$ & 74.93 & & $11-5-90$ & 75.09 & & $6-4-90$ & 75.81 \\
\hline & $8-26-91$ & 73.94 & & $8-26-91$ & 73.98 & & $6-6-90$ & 75.70 \\
\hline & & & & & & & $6-7-90$ & 75.59 \\
\hline \multirow[t]{5}{*}{ N10828 } & $5-1-90$ & 74.20 & N10466 & $5-2-90$ & 73.09 & & & \\
\hline & $7-16-90$ & 7533 & & $6-12-90$ & 74.21 & N10476 & $5-2-90$ & 70.56 \\
\hline & $11-5-90$ & 75.63 & & $11-5-90$ & 74.29 & & $5-8-90$ & 70.66 \\
\hline & $8-26-91$ & 74.86 & & $8-26-91$ & 73.29 & & $5-22-90$ & 71.61 \\
\hline & & & & & & & $6-1-90$ & $72 . C 3$ \\
\hline \multirow[t]{4}{*}{ N10329 } & $5-2-90$ & 76.94 & N10467 & $5-1-90$ & 7534 & & $6-4-90$ & 72.16 \\
\hline & $5-24-90$ & 78.42 & & $6-13-90$ & 76.51 & & $6-6-90$ & 72.12 \\
\hline & $11-5-90$ & 78.58 & & $11-5-90$ & 76.69 & & $6-7-90$ & 72.11 \\
\hline & $8-26-91$ & 78.09 & & $8-26-91$ & 76.02 & & & \\
\hline
\end{tabular}


Table 2. Water levels at selected wells near New Cassel, N.Y., 1990-91--continued

\begin{tabular}{|c|c|c|c|c|c|c|c|c|}
\hline $\begin{array}{c}\text { Well } \\
\text { number }\end{array}$ & Date & $\begin{array}{l}\text { Water } \\
\text { level }\end{array}$ & $\begin{array}{c}\text { Well } \\
\text { number }\end{array}$ & Date & $\begin{array}{l}\text { Water } \\
\text { level }\end{array}$ & $\begin{array}{c}\text { Well } \\
\text { number }\end{array}$ & Dat: & $\begin{array}{l}\text { Water } \\
\text { level }\end{array}$ \\
\hline \multirow{3}{*}{ N10477 } & $5-2-90$ & 71.36 & $\overline{\mathrm{N} 11844}$ & $8-26-91$ & $\overline{75.31}$ & N11854 & $8-2 \div-91$ & 74.67 \\
\hline & $5-31-90$ & 72.39 & & & & & & \\
\hline & & & N11845 & $8-26-91$ & 75.67 & N11855 & $8-2^{<}-91$ & 75.21 \\
\hline \multirow[t]{2}{*}{ N10478 } & $5-2-90$ & 71.25 & & & & & & \\
\hline & $5-31-90$ & 72.28 & N11846 & $8-26-91$ & 76.18 & N11856 & $8-2 \varsigma-91$ & 75.41 \\
\hline \multirow[t]{3}{*}{ N10479 } & $5-2-90$ & 69.62 & $\mathrm{~N} 11847$ & $8-26-91$ & 73.93 & N11857 & $8-2 \leq-91$ & 75.77 \\
\hline & $5-23-90$ & 70.63 & & & & & & \\
\hline & $8-27-91$ & 69.77 & N11848 & $8-26-91$ & 72.84 & N11858 & $8-2 \leq-91$ & 72.45 \\
\hline \multirow[t]{4}{*}{ N10480 } & $5-2-90$ & 69.60 & N11849 & $8-26-91$ & 73.08 & N11859 & $8-2 \leq-91$ & 72.90 \\
\hline & $5-23-90$ & 70.63 & & & & & & \\
\hline & $8-27-91$ & 69.75 & N11850 & $8-26-91$ & 73.45 & N11860 & $8-2<-91$ & 74.10 \\
\hline & & & & & & & $9-9-91$ & 73.33 \\
\hline \multirow[t]{2}{*}{ N11841 } & $8-26-91$ & 76.54 & N11851 & $8-26-91$ & 73.43 & & & \\
\hline & & & & & & N11861 & $8-2 \leqslant-91$ & 72.98 \\
\hline \multirow[t]{2}{*}{$\mathrm{N} 11842$} & $8-26-91$ & 76.59 & N11852 & $8-26-91$ & 73.45 & & & \\
\hline & & & & & & N11862 & $8-2 ؟-91$ & 71.82 \\
\hline N11843 & $8-26-91$ & 74.64 & N11853 & $8-26-91$ & 73.86 & & & \\
\hline
\end{tabular}

appropriate locations for additional wells. In 1990, 22 new wells were installed. Water samples from each new well were analyzed qualitatively on the USGS gas chromatograph as the well was installed to aid in the selection of the next site. In 1991 a total of 56 wells were sampled; 30 were NCDH wells sampled in 1990, 4 were other observation wells sampled in 1990, and 22 were the newly installed wells. All organic and inorganic analyses were performed by the NCDH laboratory, which participates in the USGS standardreference water-sample program. Results of analyses representing the two sampling periods (May through August 1990 and January through May 1991) are presented in table 3 (organic constituents) and table 4 (inorganic constituents) in the section on water-quality data.

\section{Water-Sampling Procedure}

Water levels were measured, and the total volume of water in the casing was calculated before each well was sampled. A submersible pump, fitted with a Teflon ${ }^{1}$ hose, was lowered to about $5 \mathrm{ft}$ below the

\footnotetext{
${ }^{1}$ Use of trade, product, or firm names in this publication is for descriptive purposes only and does not imply endorsement by the U.S. Government.
}

water level, then the pump was turned on. Three casing volumes were evacuated in this manner. During this time, water samples were taken periodically and checked for temperature, $\mathrm{pH}$, and specific conductance. After at least three casing volum os of water had been removed and the three measured properties stabilized, water samples were collected. Samples for inorganic analyses were collected in $\mathrm{pc}^{\mathbf{l}}$ yethylene bottles and filtered and (or) acidified as requested by the NCDH laboratory. Samples for VOC a alyses were collected in $40-\mathrm{mL}$ glass vials with Teflon caps. Care was taken to minimize contact with air so that the samples would contain no bubbles when the caps were sealed. All sample bottles were supplied by the NCDH laboratory. The samples were immediately placed on ice for transport to the NCDH laboratory.

During the 1991 sampling, 46 of the 56 wells were sampled twice; once by the method described above, and once with a Tefion bailer. Both samplers were used because NCDH requested tr at a bailer be used for all sampling. Because a submersible pump was used to evacuate three casing volumes, a sample was collected from the pump for comparison with the bailer sample at all wells. After the we'l was evacuated by the pump, and the first set of samples had been collected, the bailer sample was collected. First, the bailer was carefully lowered into the well to just 
below the water table. A check valve at the bottom of the bailer allowed the inflow of water with no mixing of air. When full, the bailer was withdrawn from the well, and a sample was immediately collected from a Teflon spigot inserted into the bottom of the bailer. Samples were placed in iced coolers for transport to the NCDH laboratory.

\section{Quality Assurance}

The practices that were used to ensure that sampling techniques were sound, that samples were representative of formation water, and that the laboratory could generate reproducible results, are described below.

Before a water sample was collected, at least three casing volumes were evacuated from the well, and consecutive measurements of temperature, $\mathrm{pH}$, and specific conductance were stable and reproducible. Comparison of samples collected by the two techniques described earlier from each well revealed no difference in VOC concentrations, indicating that either the sampling method was adequate for this study and that samples were not mislabeled.

Duplicate samples were collected for preliminary screening of all organic constituent analyses. One set of these samples was run through the USGS gas chromatograph flame-ionization detector overnight (tapwater blanks were run between each sample) before the second set of samples was analyzed at the NCDH laboratory; the main reason was to wam the laboratory about highly contaminated samples, but it also provided another check for mislabeled sample bottles. No mislabeled bottles were discovered.

A third sample was collected at 12 percent of the wells sampled ( 9 of the 74 wells). Over the two sampling periods, this represents about 8 percent of the wells sampled in 1990 (4 of the 52 wells) and about 9 percent of the wells sampled in 1991 ( 5 of the 56 wells). The third sample was sent to the NCDH laboratory as a duplicate for a quality check on the laboratory techniques.

Finally, upon completion of sampling at each well, both samplers (pump and bailer) were washed off and flushed with tap water, and a blank sample was collected from each. These "flush samples" were analyzed on the USGS gas chromatograph flame-ionization detector. No volatile compounds were detected, indicating that cross-contamination of VOC's between wells was unlikely.

\section{Borehole Geophysical Surveys}

Of the 22 new observation wells, 21 were loggad with a gamma probe and a electromagnetic-induction probe. The shallow well of a doublet (N11851, fig. 3) and was omitted because the deeper well, N11852, was logged. All logging was done through PVC casing, and no metal was used in the construction of tre wells except for cast iron curb boxes. Data were logged downward and upward. Scaling and sensitivity adjustments were made only as the probe was descending so that a log with consistent settings wəs obtained during the ascent. Attempts were made to calibrate the electromagnetic-induction probe according to the manufacturer's procedures.

The probes and cables were washed with tap water and wiped dry after logging to minimize the potential for cross-contamination between wells. Gamma and electromagnetic-conductivity logs are presented in the section on geophysical data (fig. 4).

\section{WATER-QUALITY DATA}

This section presents results of analyses of sam ples collected from the 74 wells in the New Cassel area from May 1990 through October 1991.

\section{Organic-Constituent Analyses}

The NCDH laboratory analyzed samples for 21 volatile-halogenated compounds and 9 volatile-aromatic compounds in 1990 and, in 1991, analyzed for the same 21 volatile-halogenated compounds but increased the number of volatile-aromatic compourds to 25. Results of these analyses are given in table 3 (at end of report).

\section{Inorganic-Constituent Analyses}

In 1990-91, the NCDH laboratory analyzed the same samples for inorganic constituents and other properties, including $\mathrm{pH}$ and specific conductance. Field values for $\mathrm{pH}$, specific conductance, and sample temperature were measured when the sample was c cllected. Results of the analyses and field measurements are in table 4 (at end of report). 


\section{GEOPHYSICAL DATA}

Of the 22 new observation wells, 21 were logged with a gamma probe and an electromagnetic-induction probe. Well N11851 (one of a doublet) was not logged because its deeper companion well (N11852) was logged. The gamma and EM logs from each well are placed side by side for comparison in figure 4 .

The occasional large, narrow spikes recorded at depth probably reflect stray metal fragments from buried construction debris or the backfill material. Difficulties in calibrating the electromagnetic-induction probe resulted in some negative values; for this reason, conductivity values are omitted from the $\mathrm{X}$ axes.

The screened zone is indicated on the electromagnetic-induction logs as a small rectangle along the depth scale. Laboratory results of specific con- ductance of ground-water samples from the 1991 sampling are indicated.

\section{REFERENCES CITED}

Dvirka and Bartilucci, 1986, Investigations of contaminated aquifer segments, Nassau County, New York: Syosset, N.Y., Dvirka and Bartilucci, Consulting Engineers [unpaginated].

Franke, O.L., and McClymonds, N.E., 1972, Summary of the hydrologic situation on Long Island, New York, as a guide to water-management alternatives: U.S. Geological Survey Professional Paper 627-F, 5s p.

Long Island Lighting Company, 1991, Population survey 1991: Hicksville, N.Y., 38 p.

Smolensky, D.A., Buxton, H.T., and Shernoff, P.K., 1989, Hydrologic framework of Long Island, New York: U.S. Geological Survey Hydrologic Investigations Atlas 709, 3 sheets, scale 1:250,00. 


\section{$\mathrm{N}-11841$}

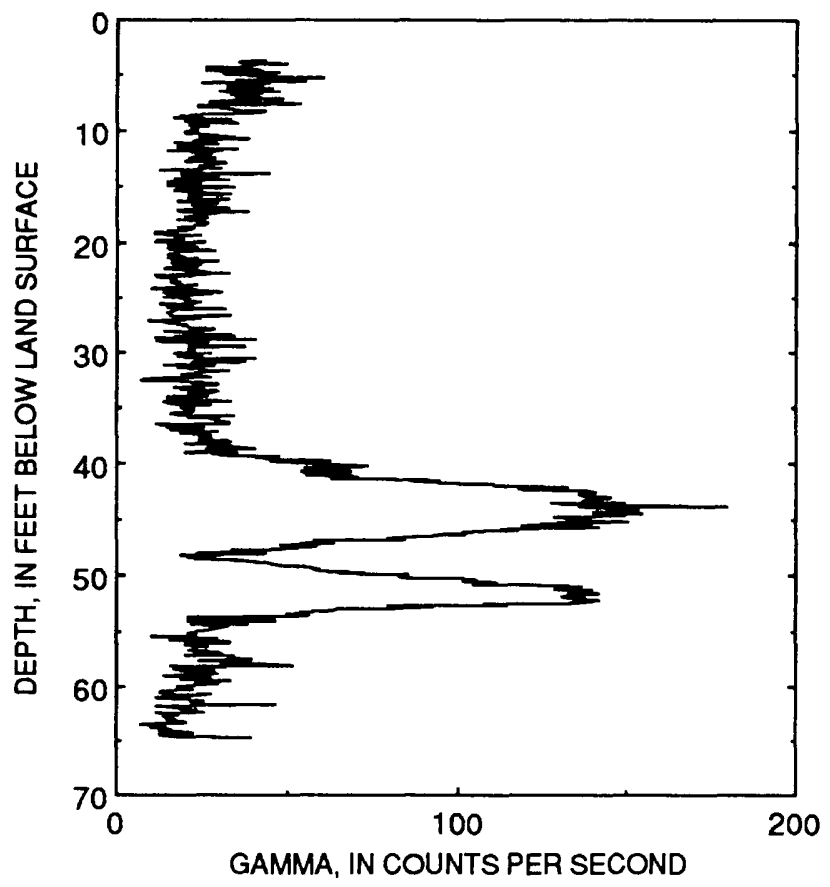

\section{$\mathrm{N}-11842$}

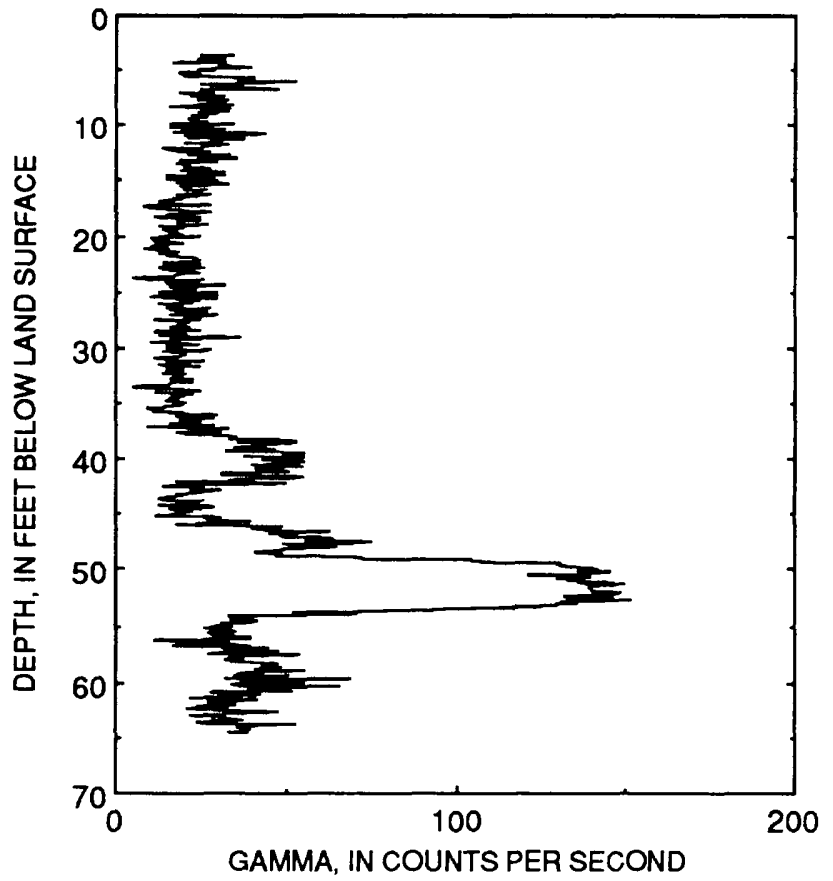

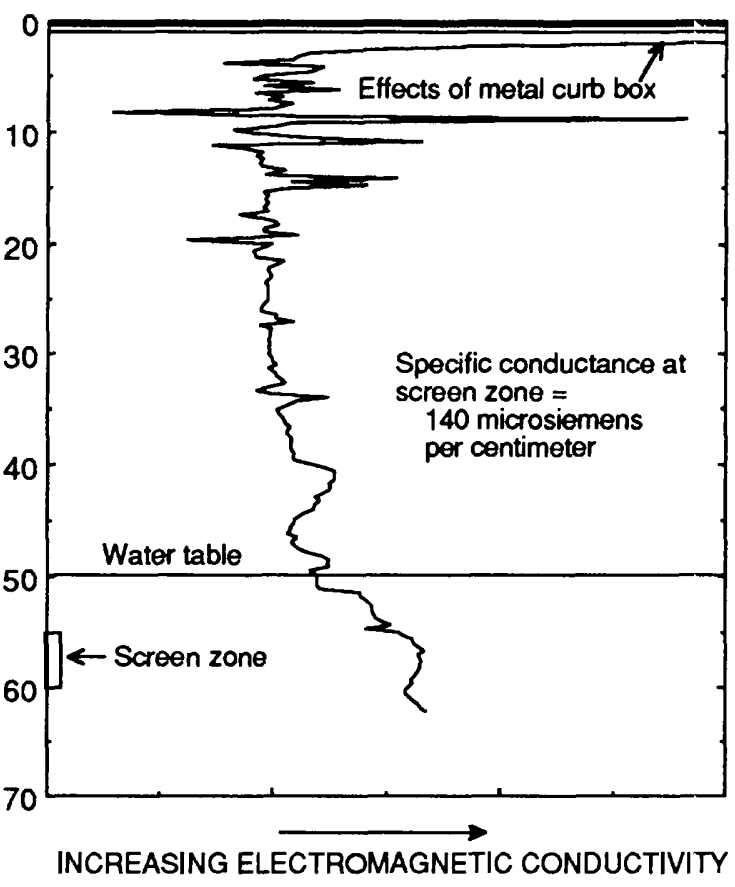

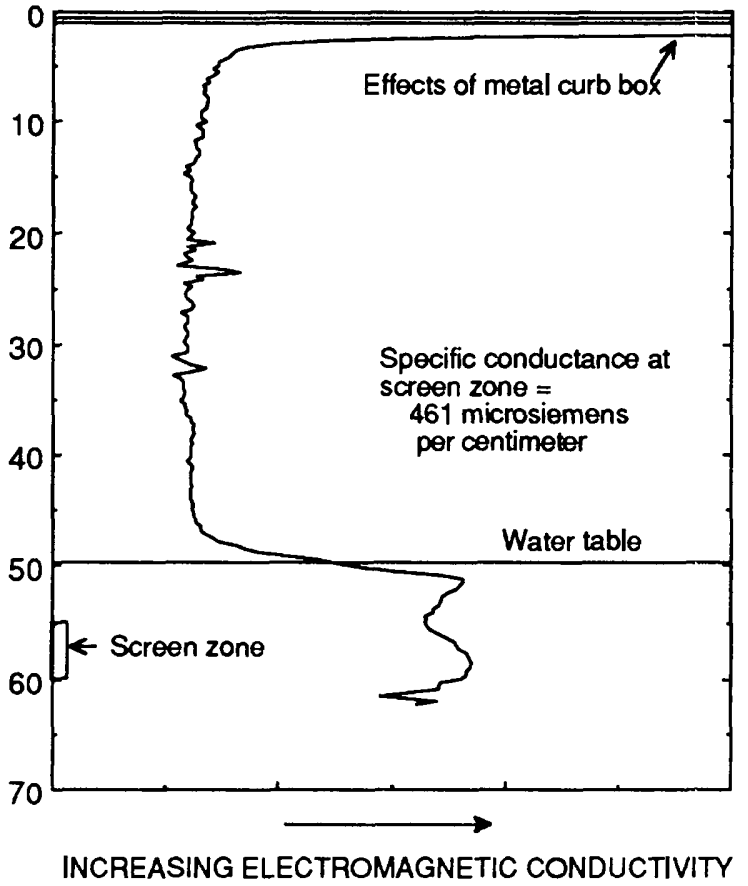

Figure 4. Gamma and electromagnetic (EM)-induction logs from 21 selected newly installed wells in the study area, Nassau County, N.Y. (Well locations are shown in fig. 3.) 

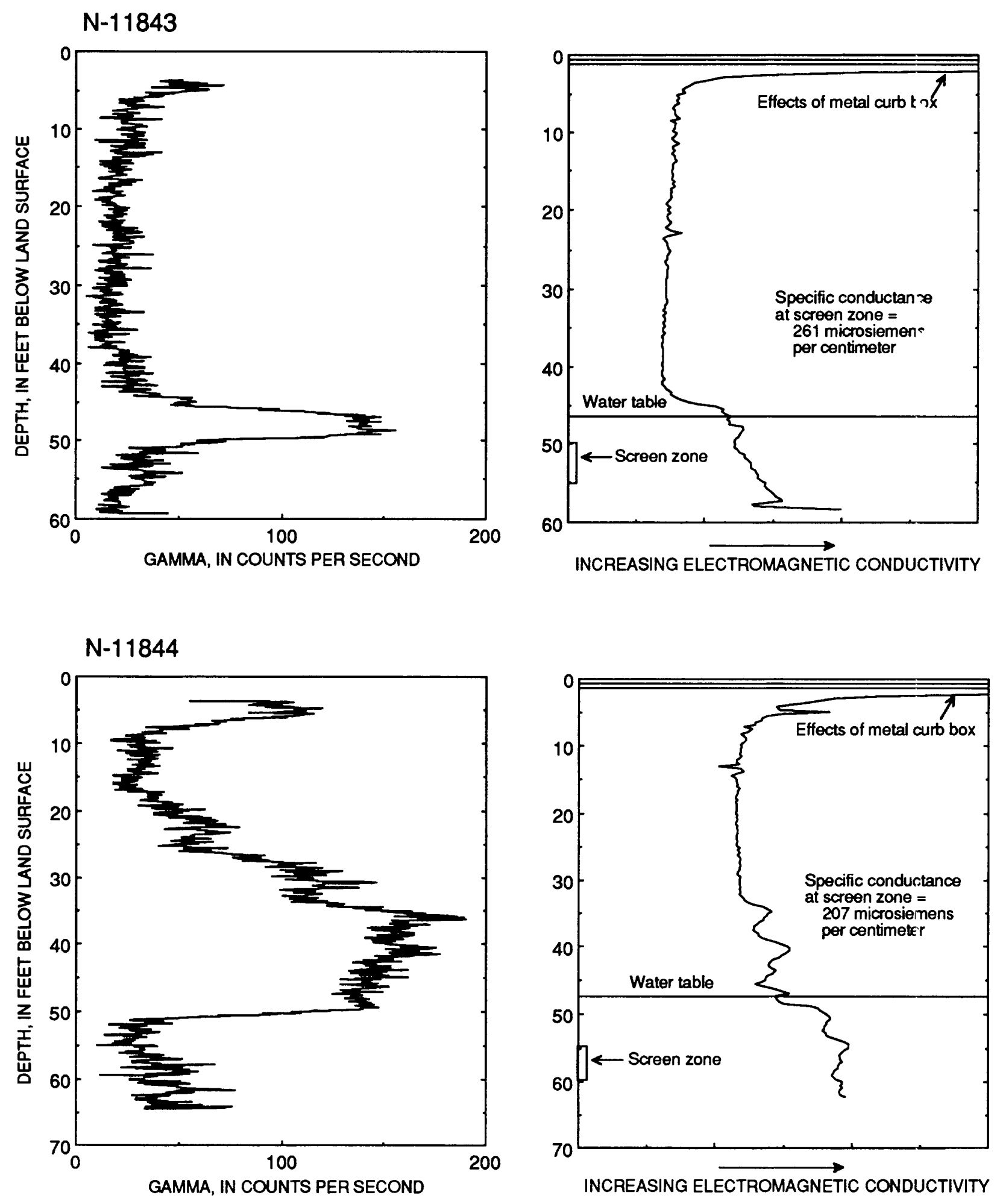

Figure 4. Continued. 


\section{$\mathrm{N}-11845$}
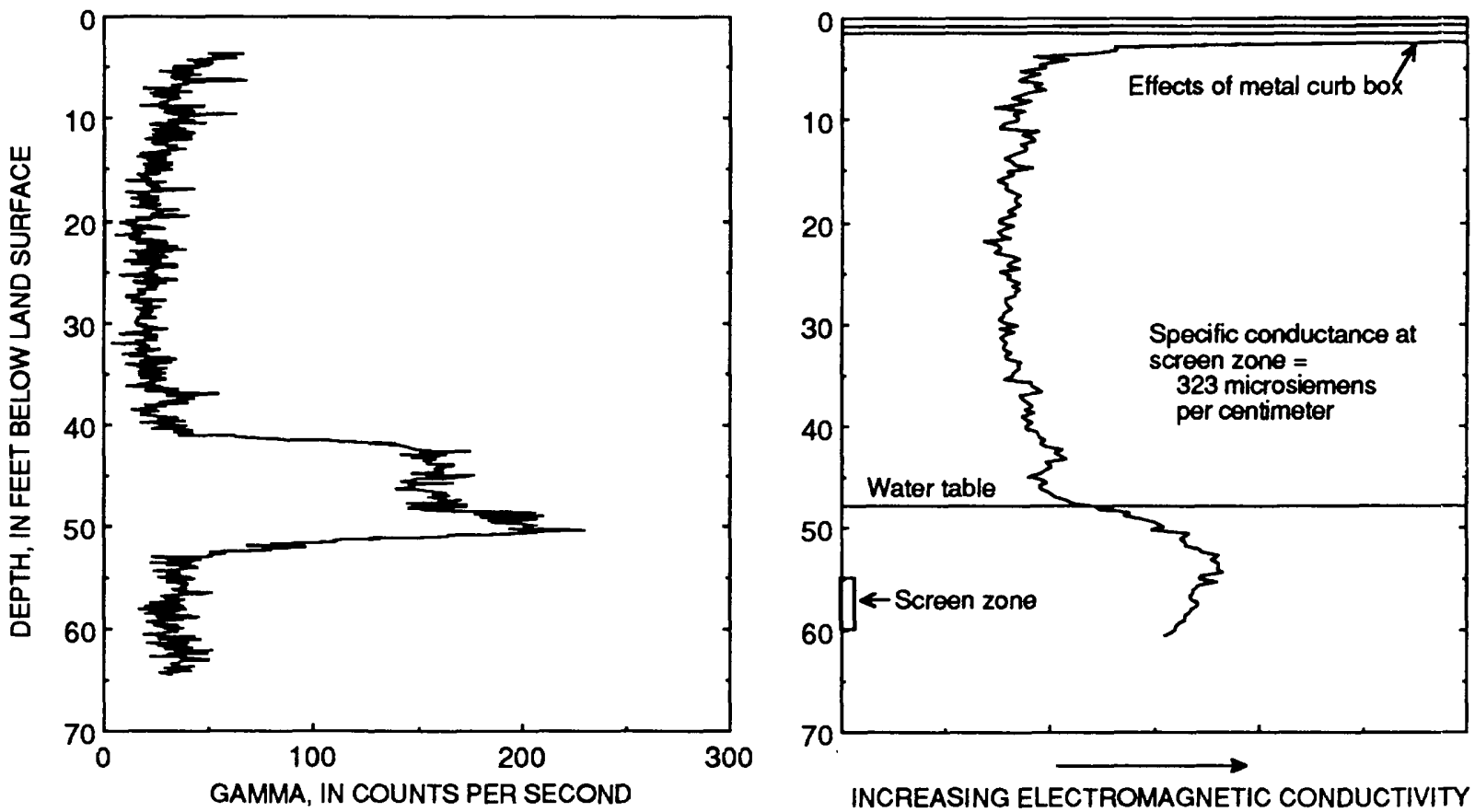

\section{$\mathrm{N}-11846$}

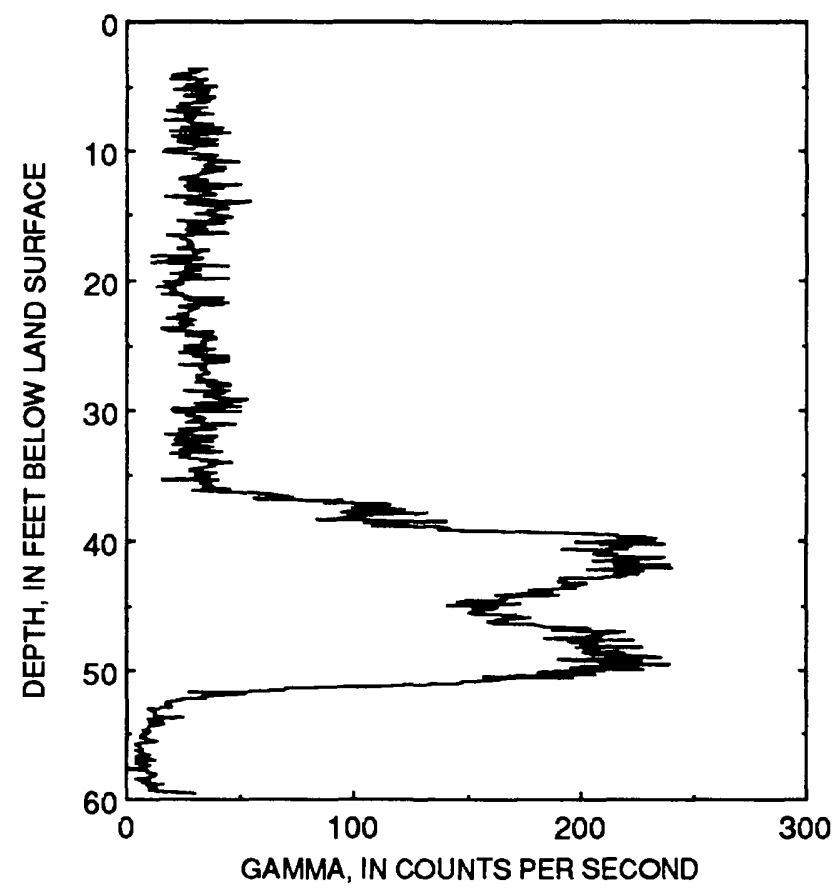

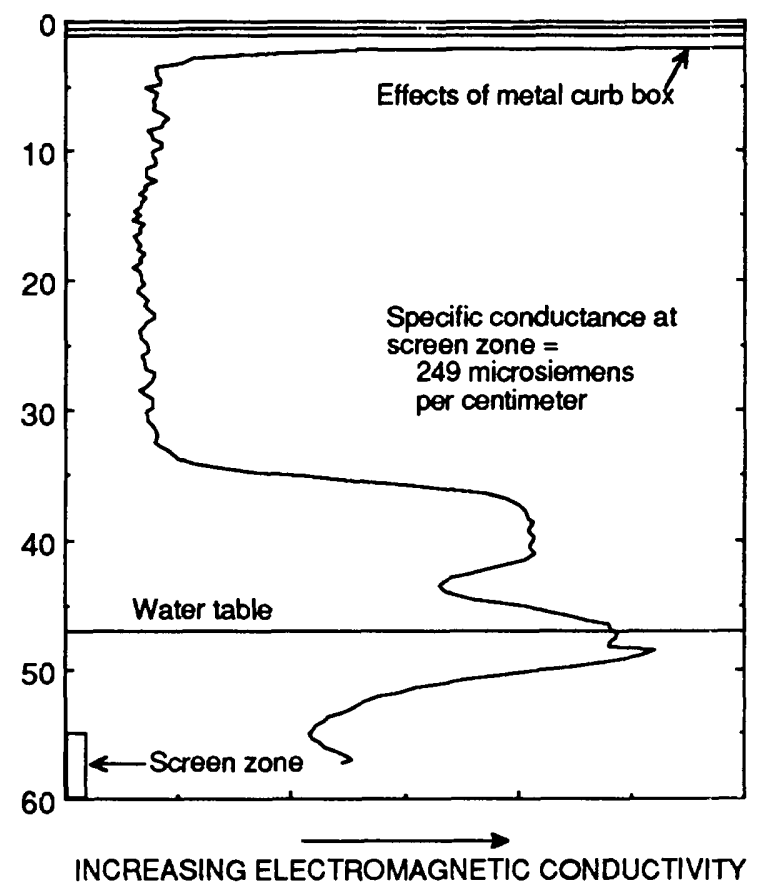

Figure 4. Continued. 

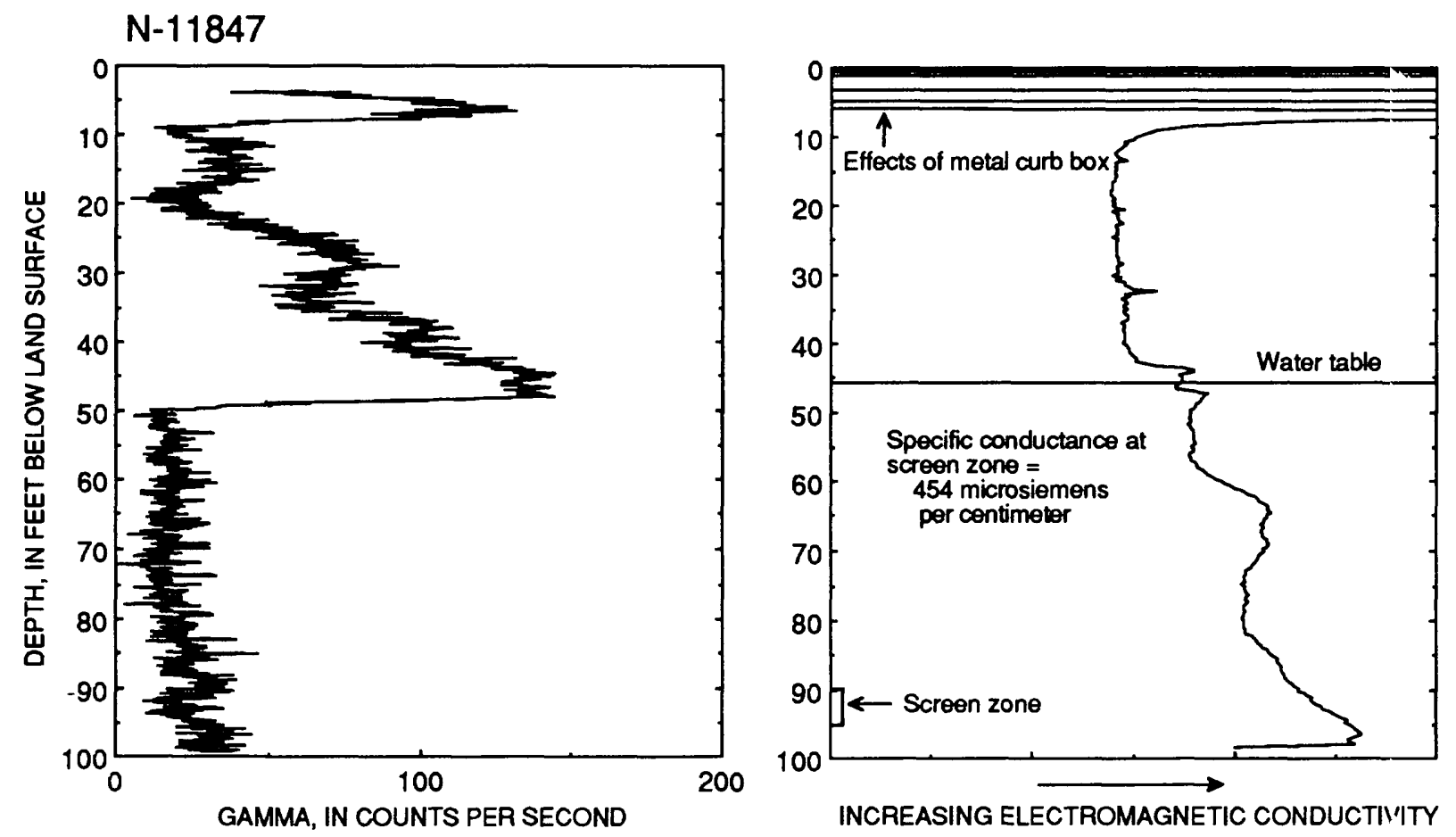

\section{N-11848}
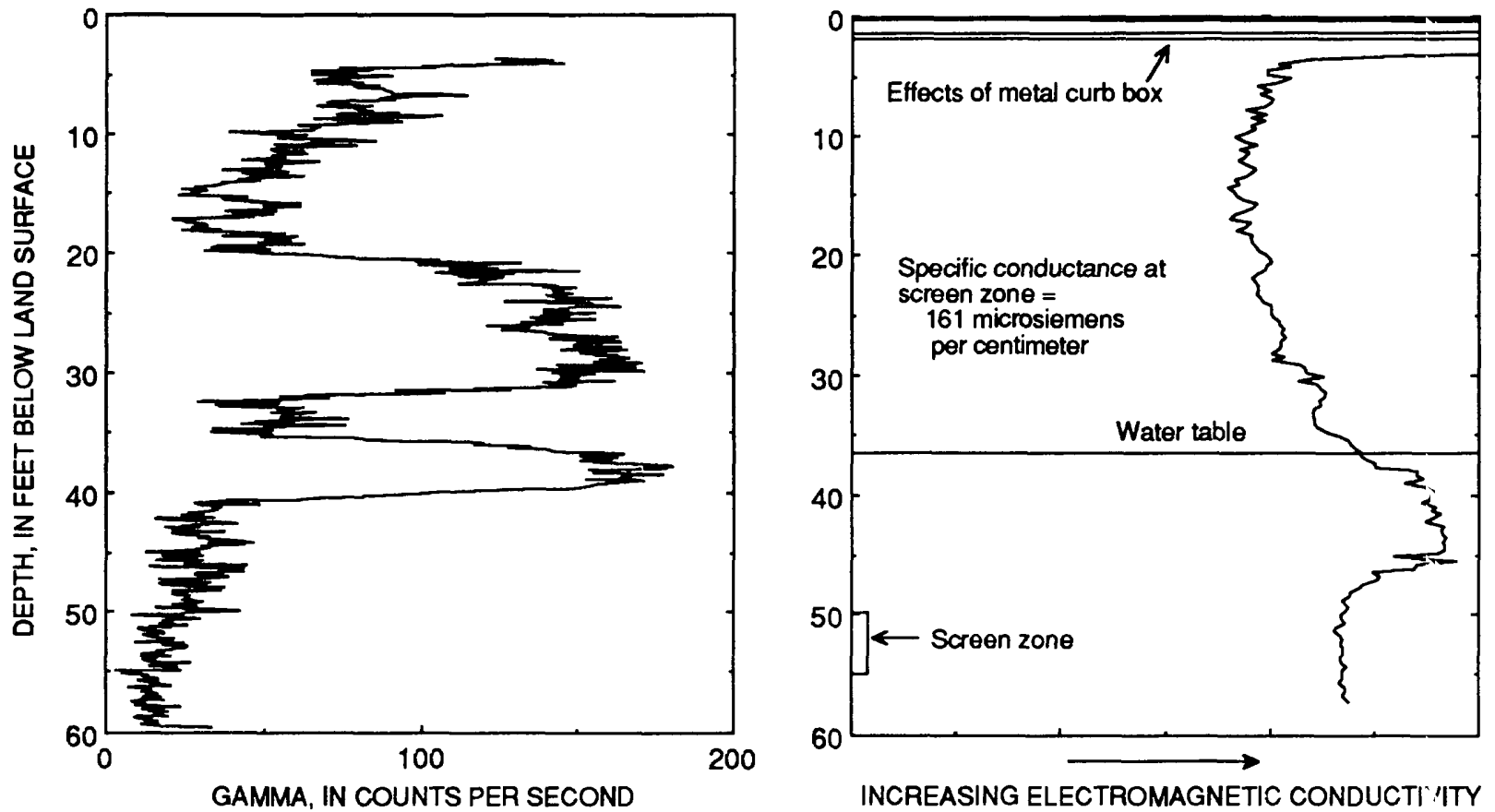

Figure 4. Continued. 

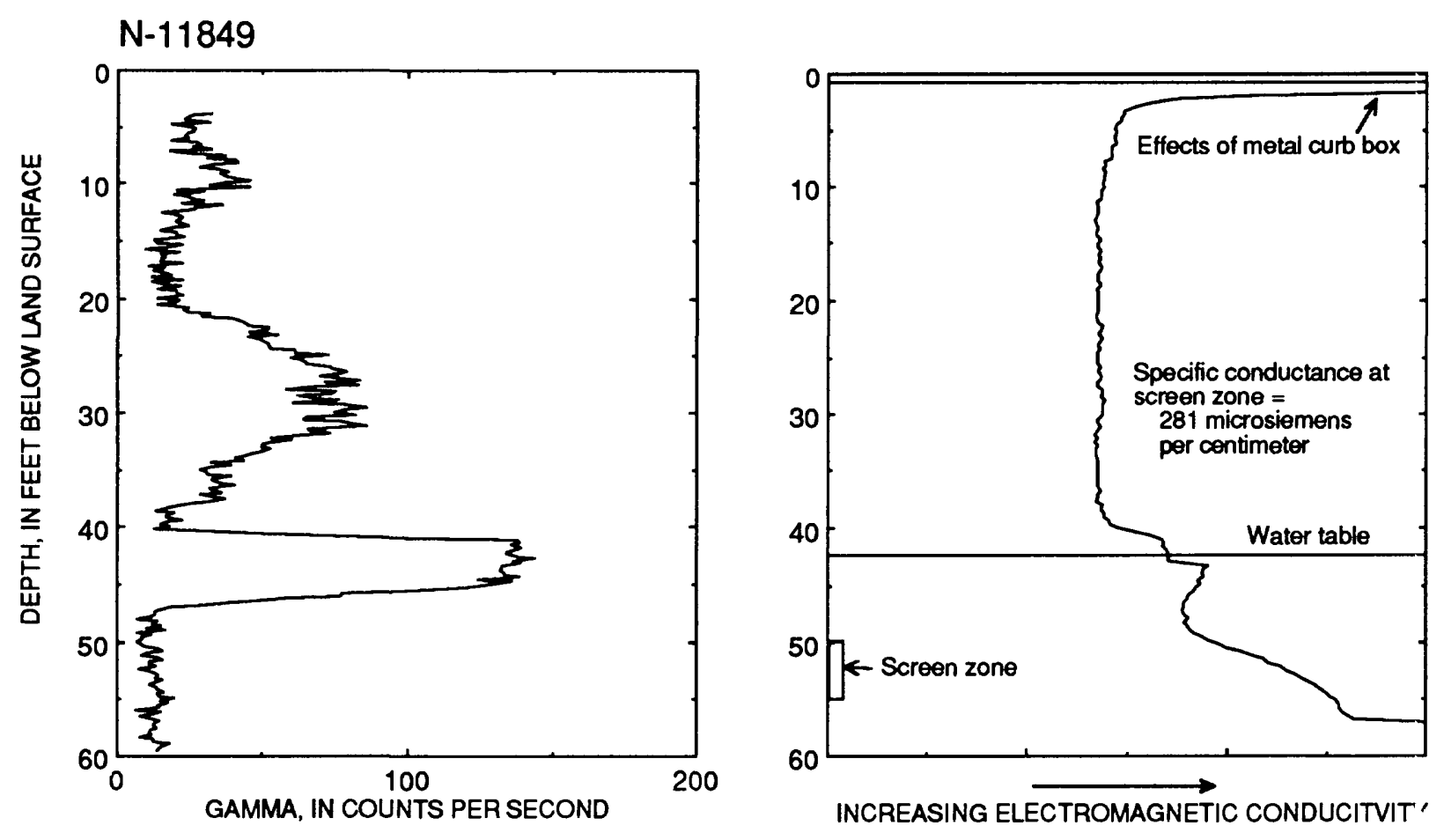

$\mathrm{N}-11850$
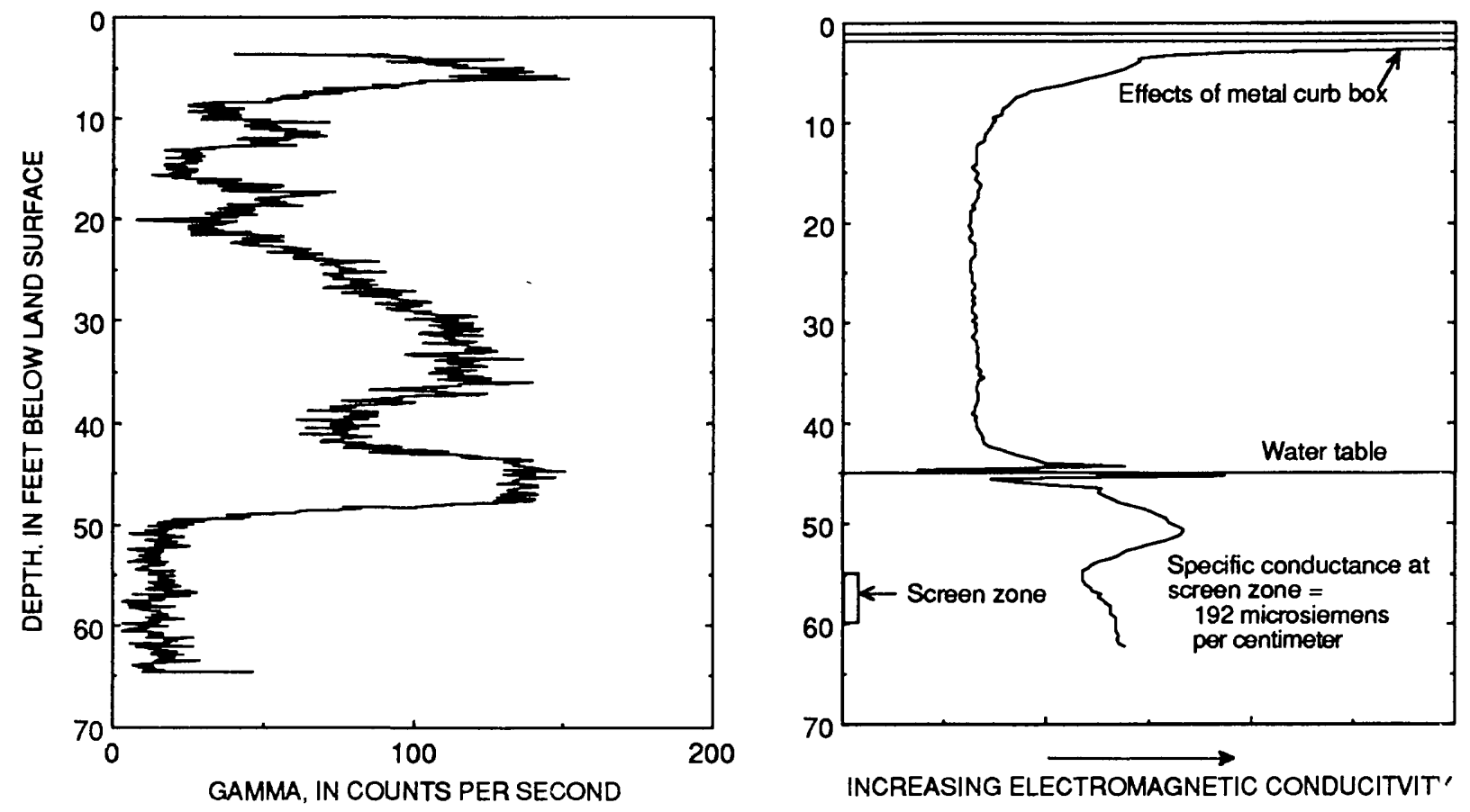

Figure 4. Continued. 


\section{$\mathrm{N}-11852$}

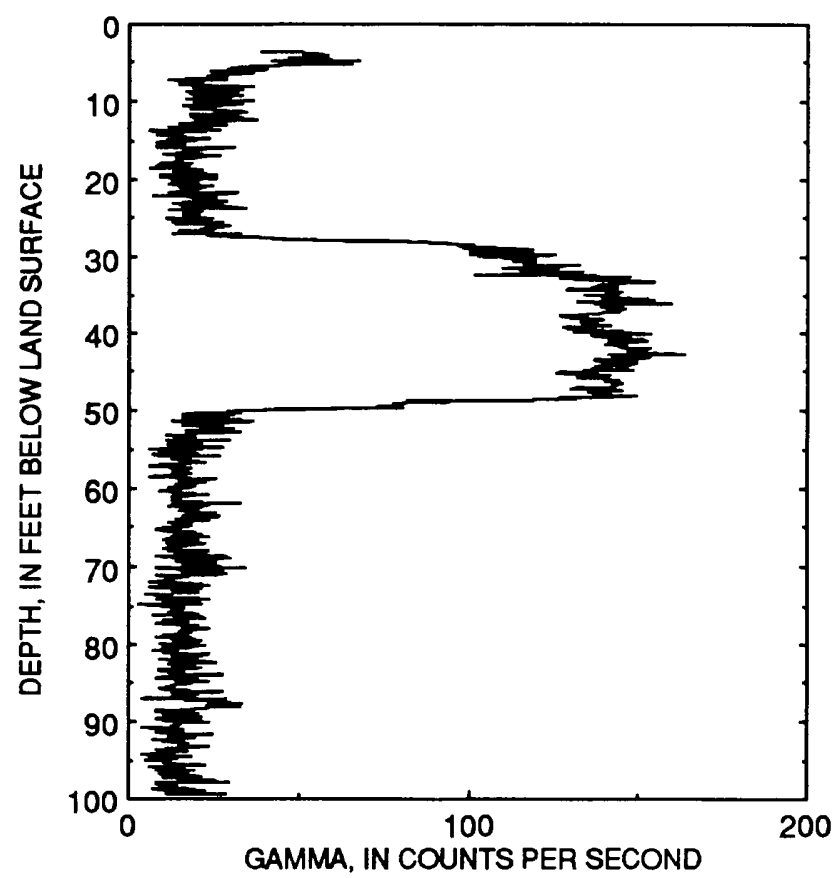

\section{$\mathrm{N}-11853$}

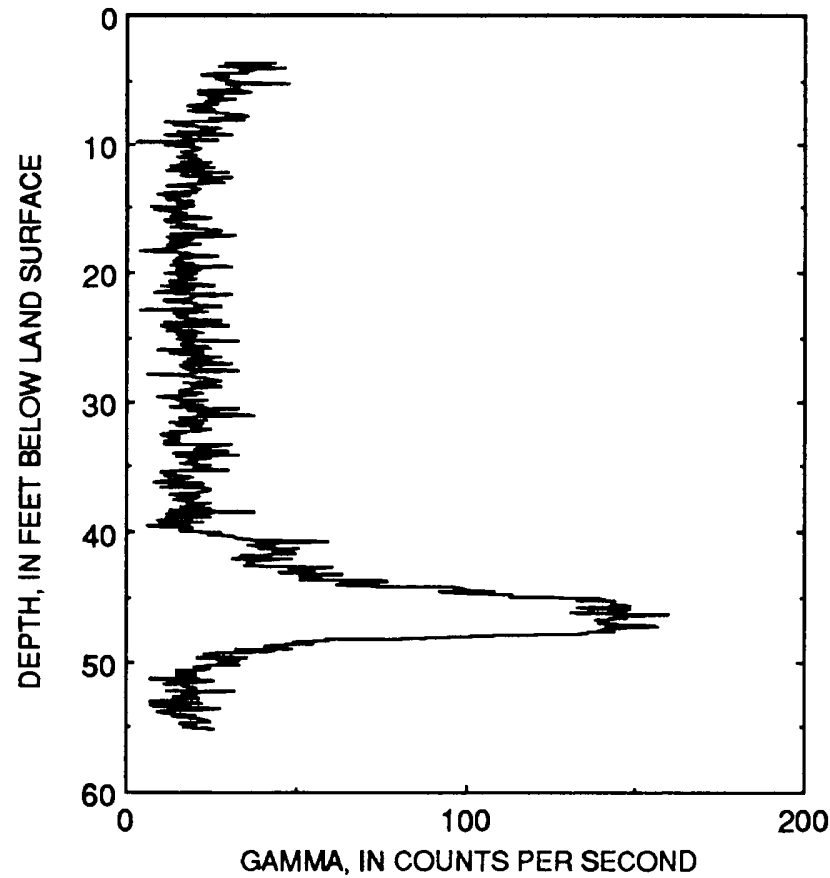

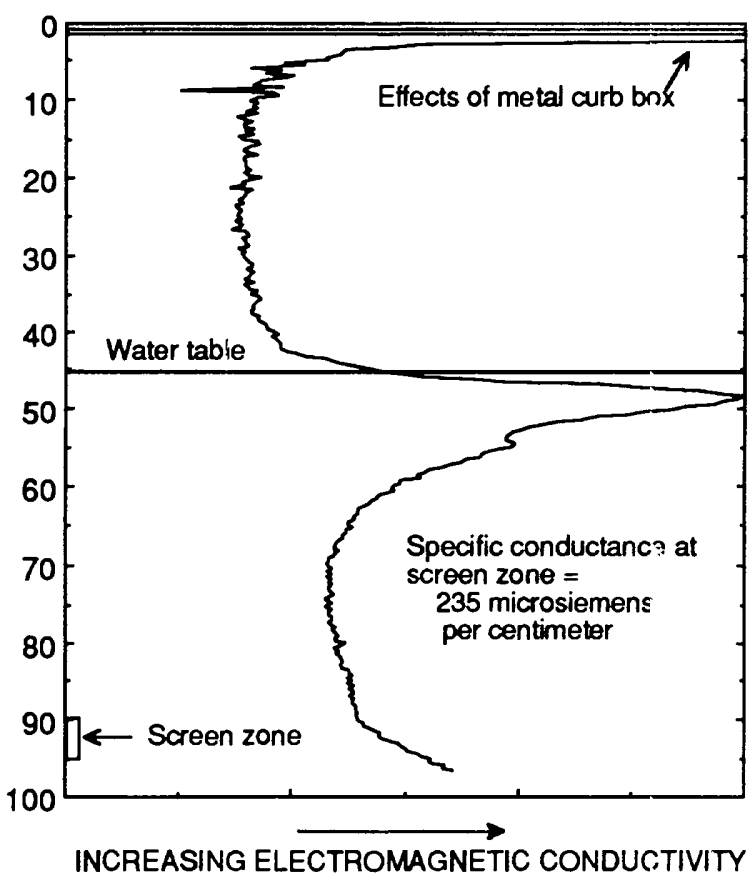

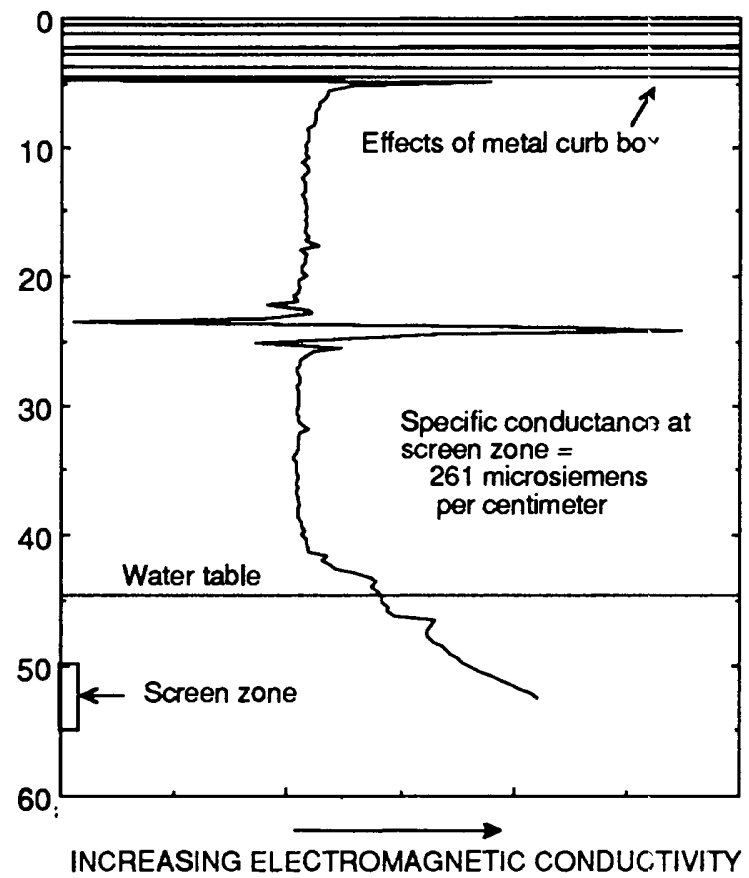

Figure 4. Continued. 

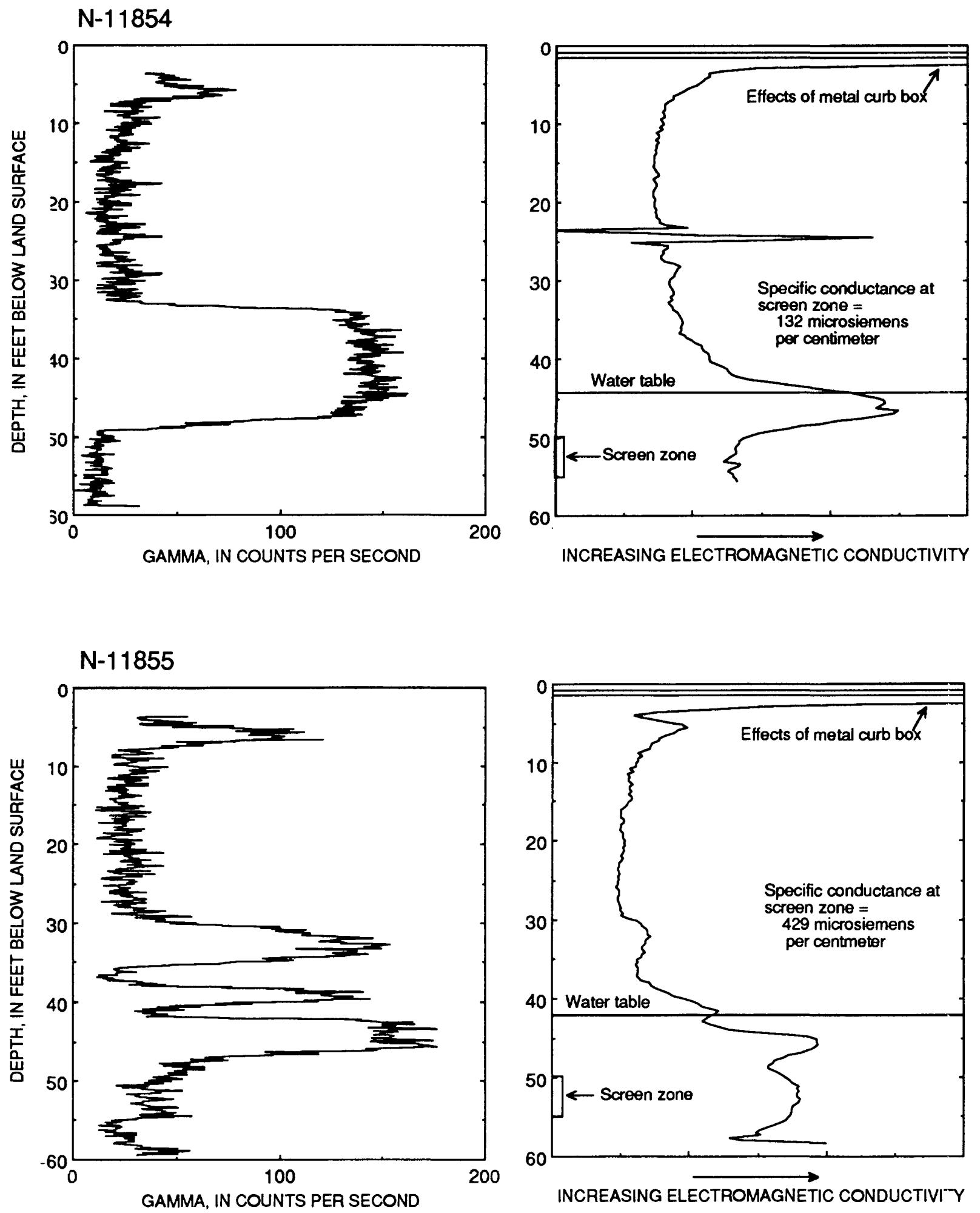

Figure 4. Continued. 

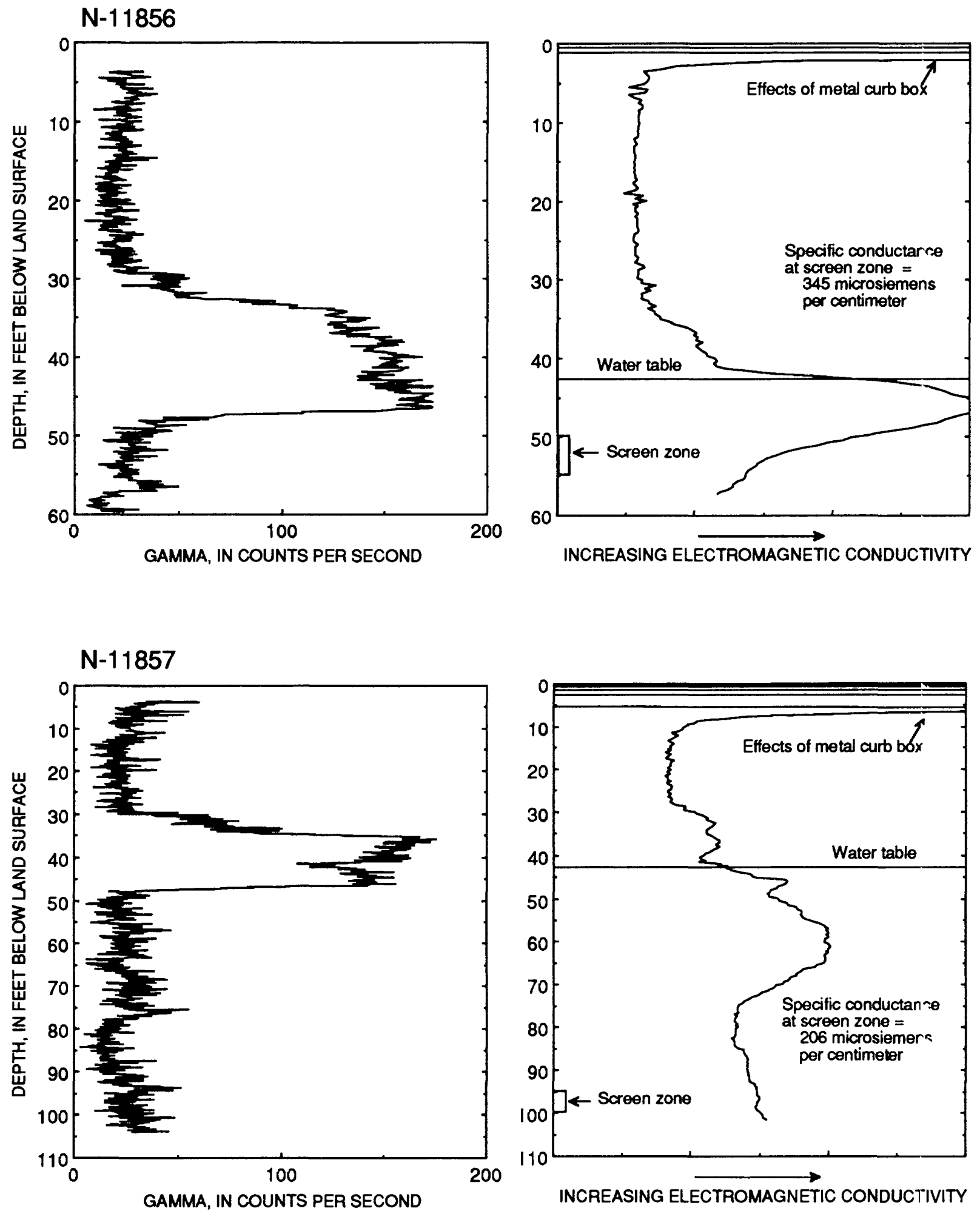

Figure 4. Continued. 

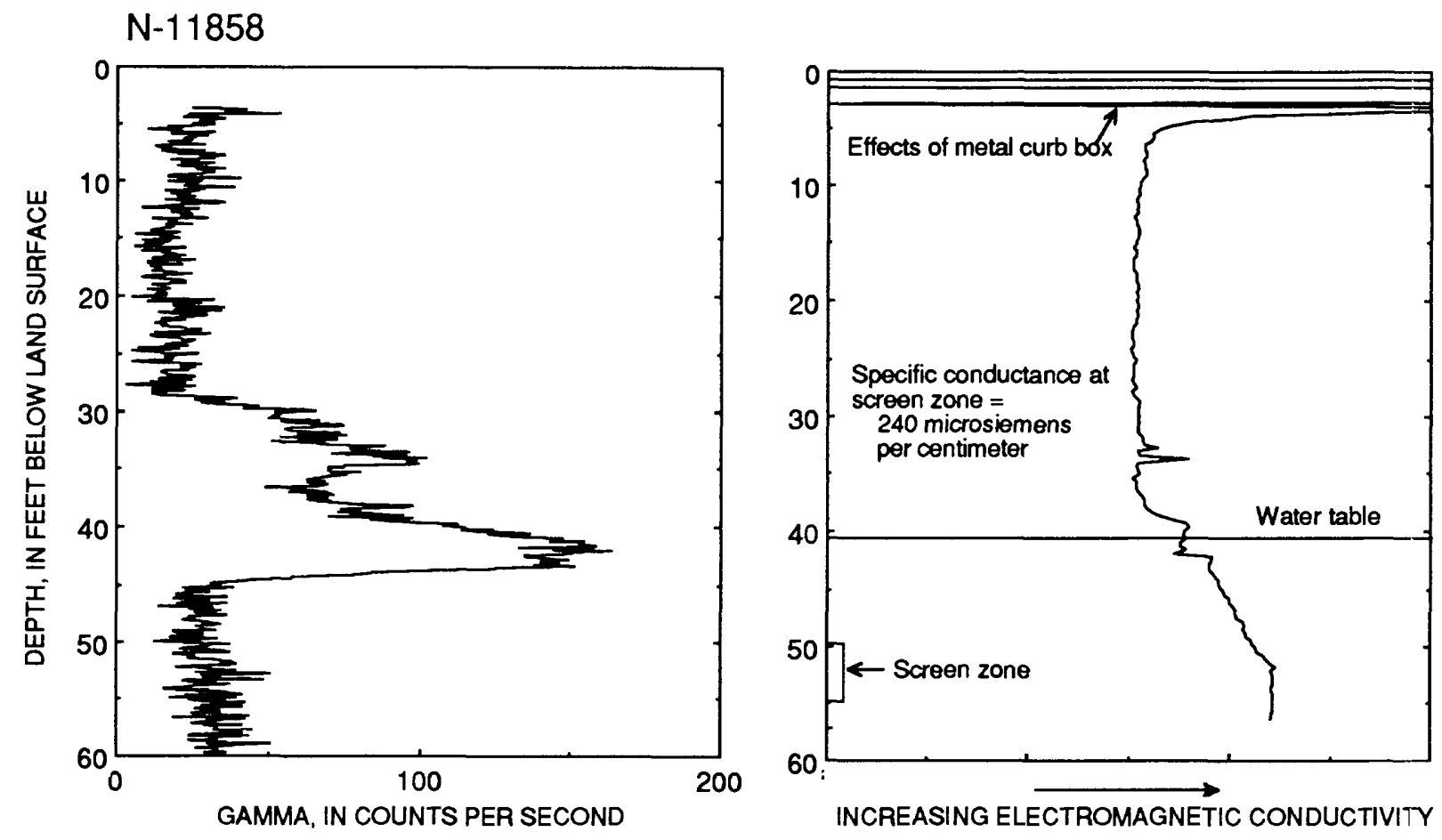

\section{N-11859}
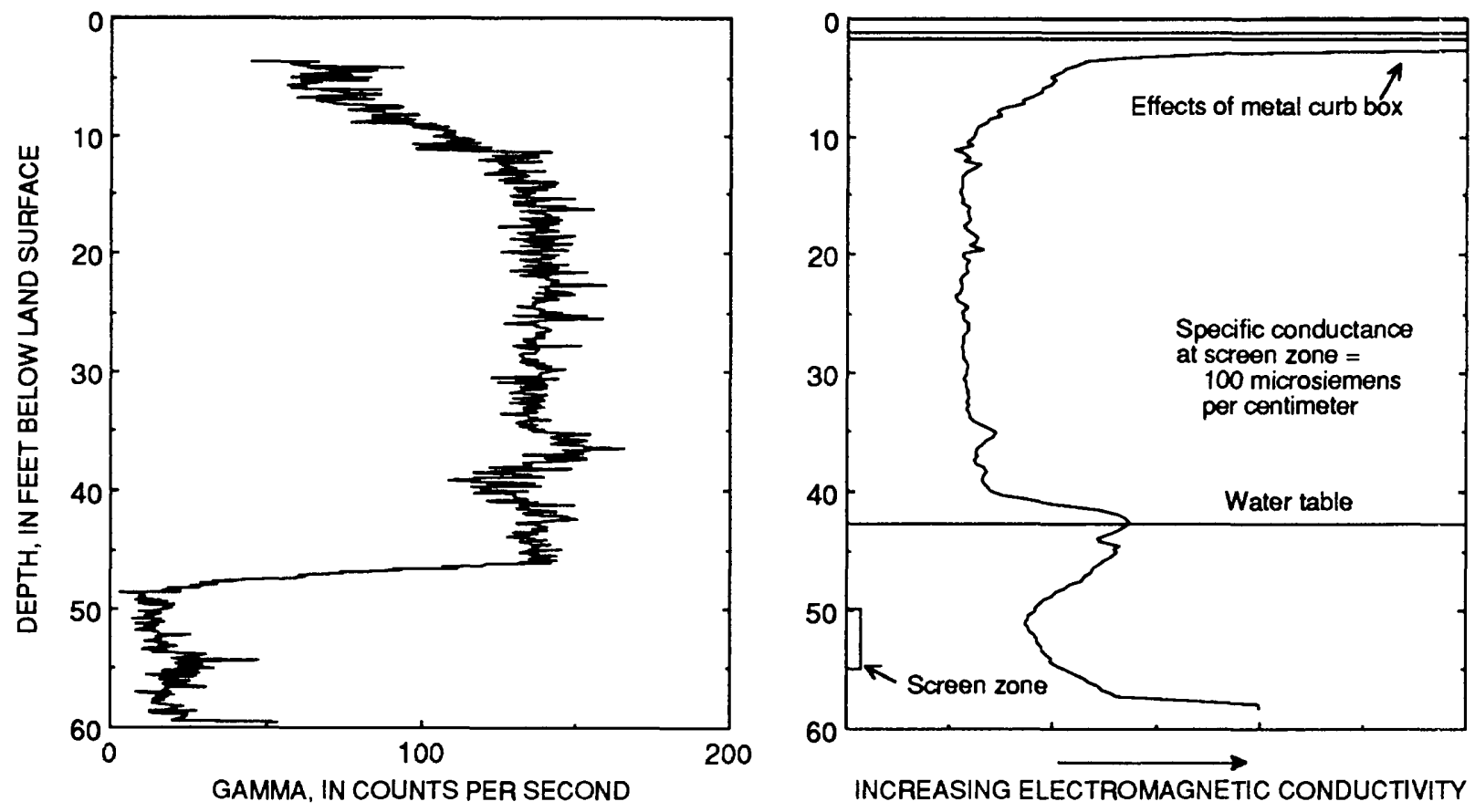

Figure 4. Continued. 

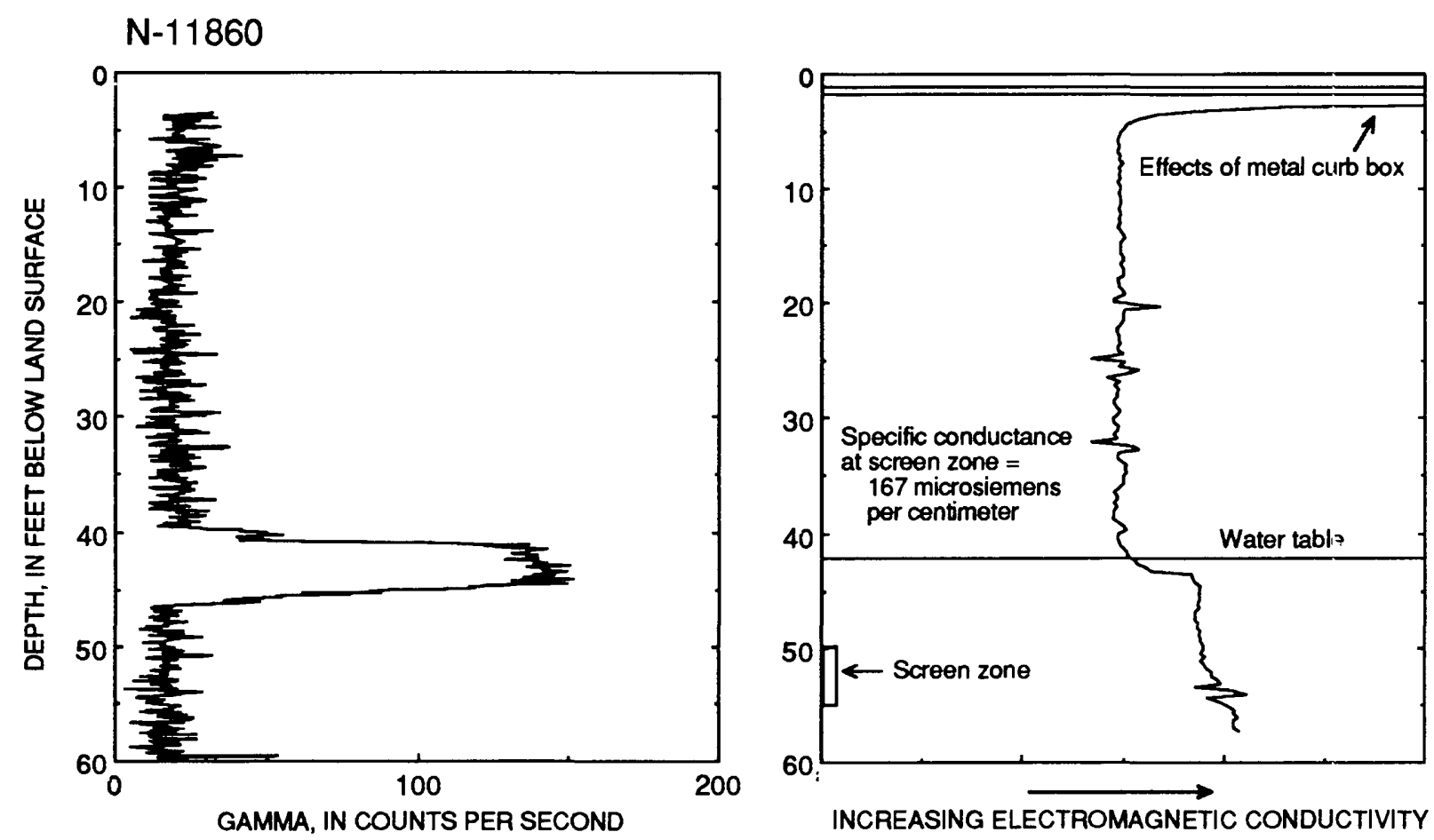

N-11861
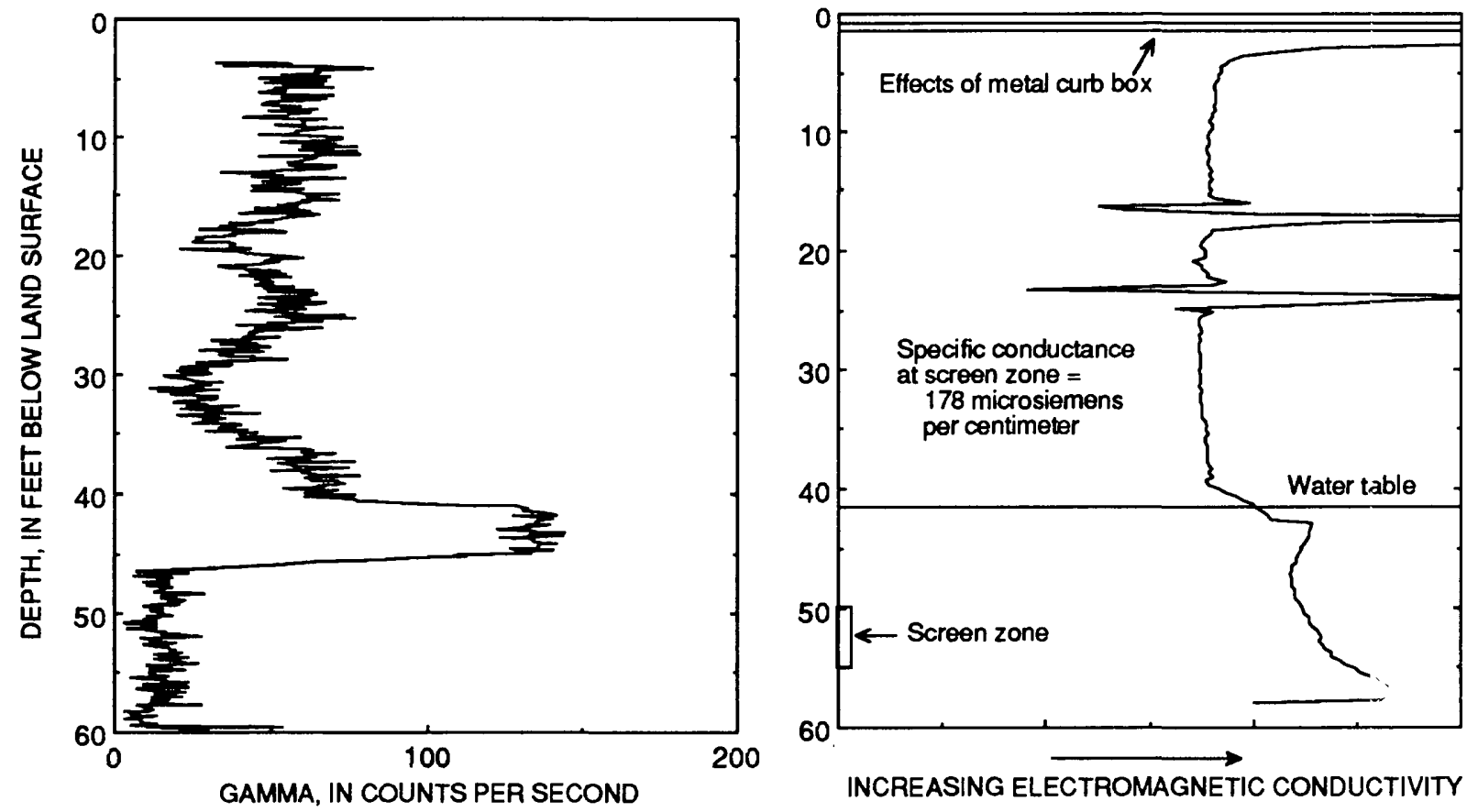

Figure 4. Continued. 

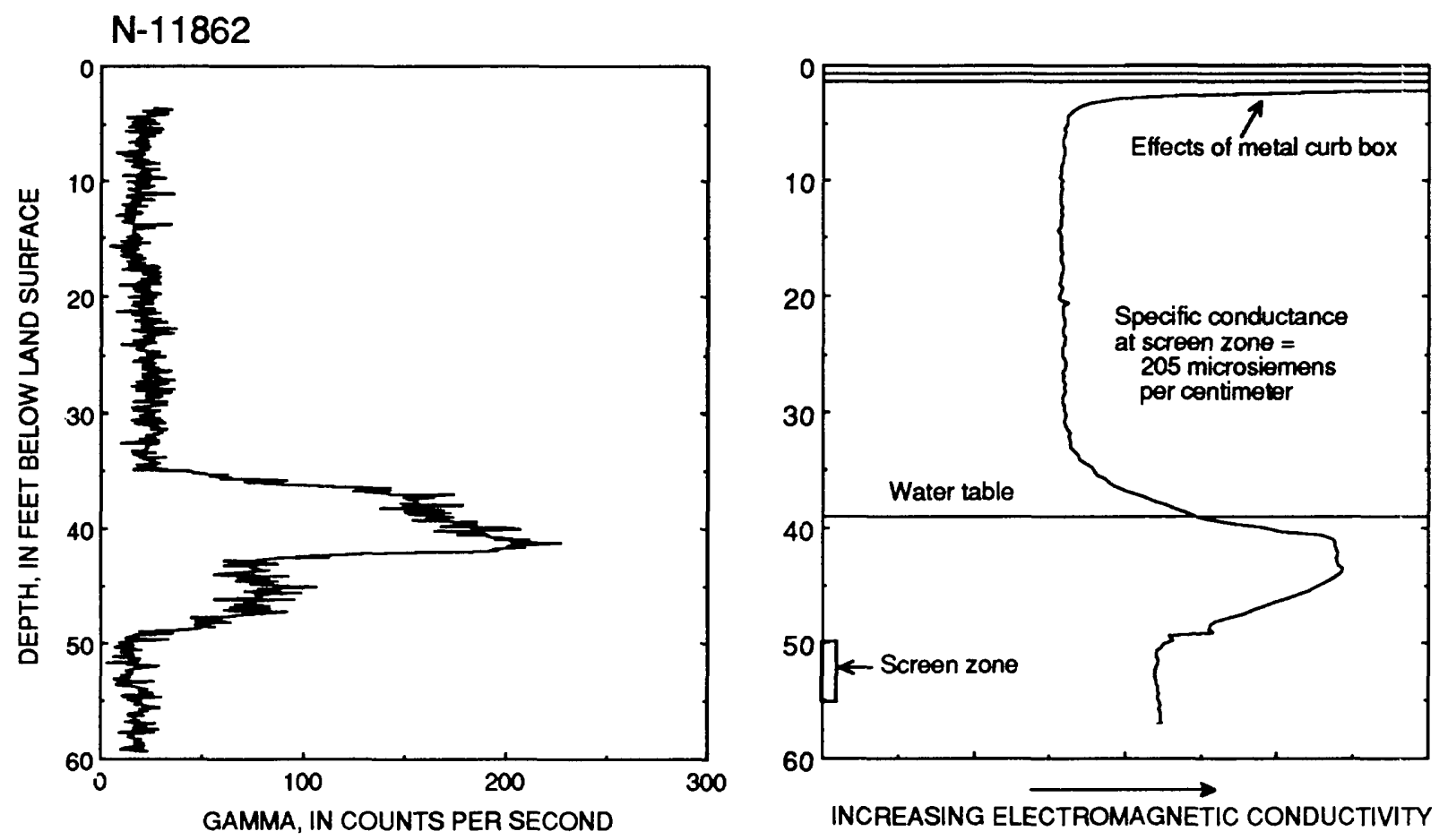

Figure 4. Continued. 


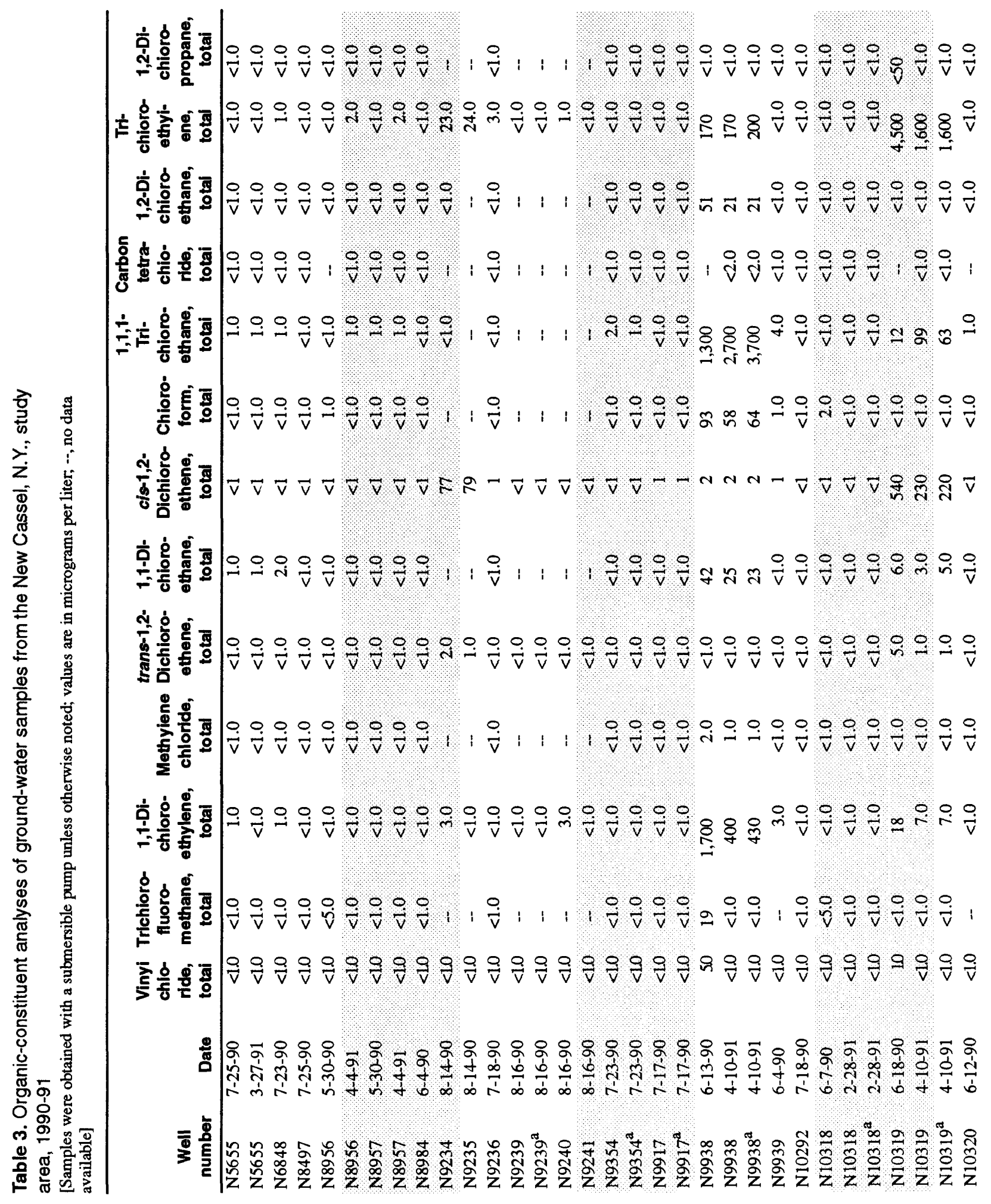




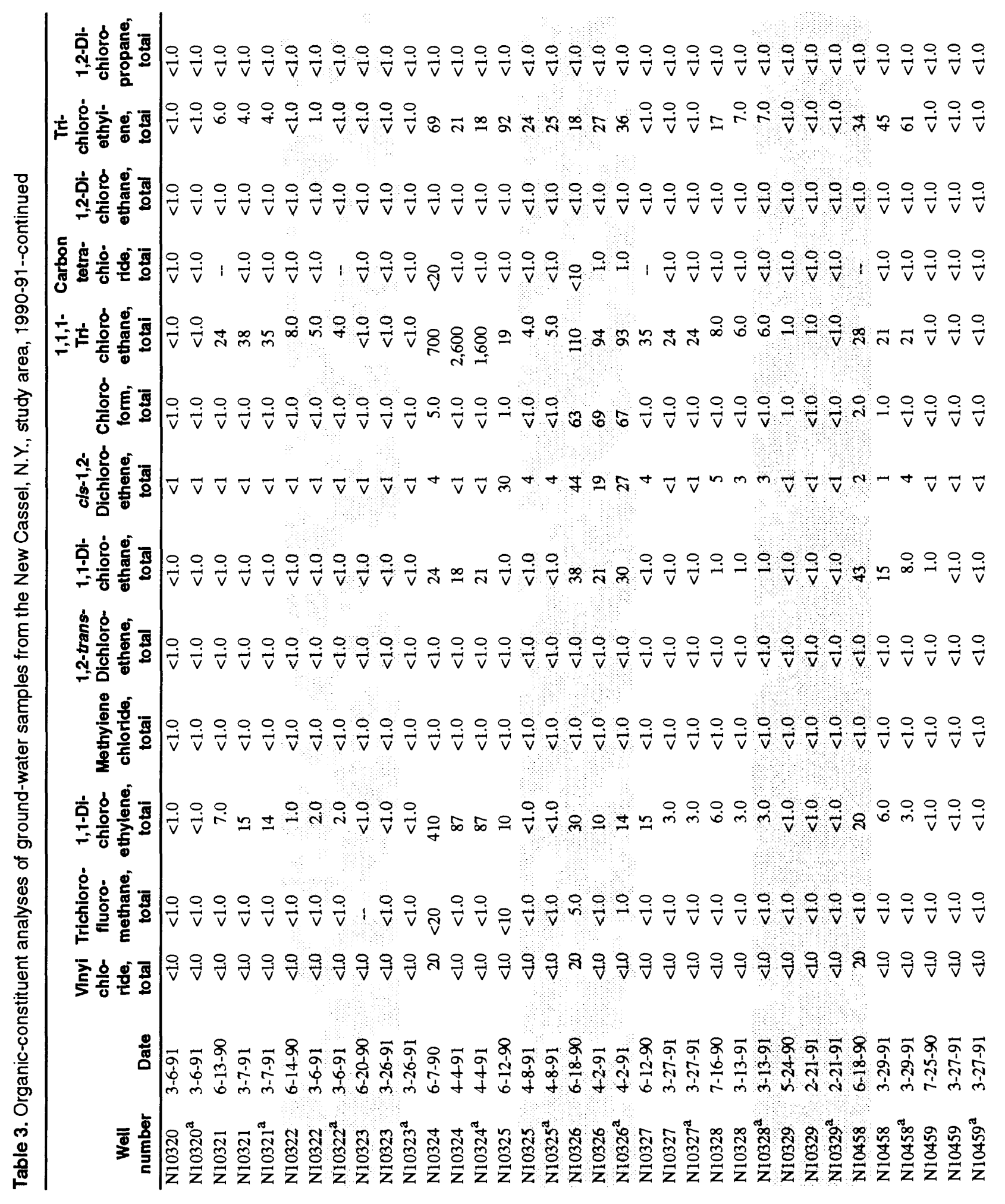




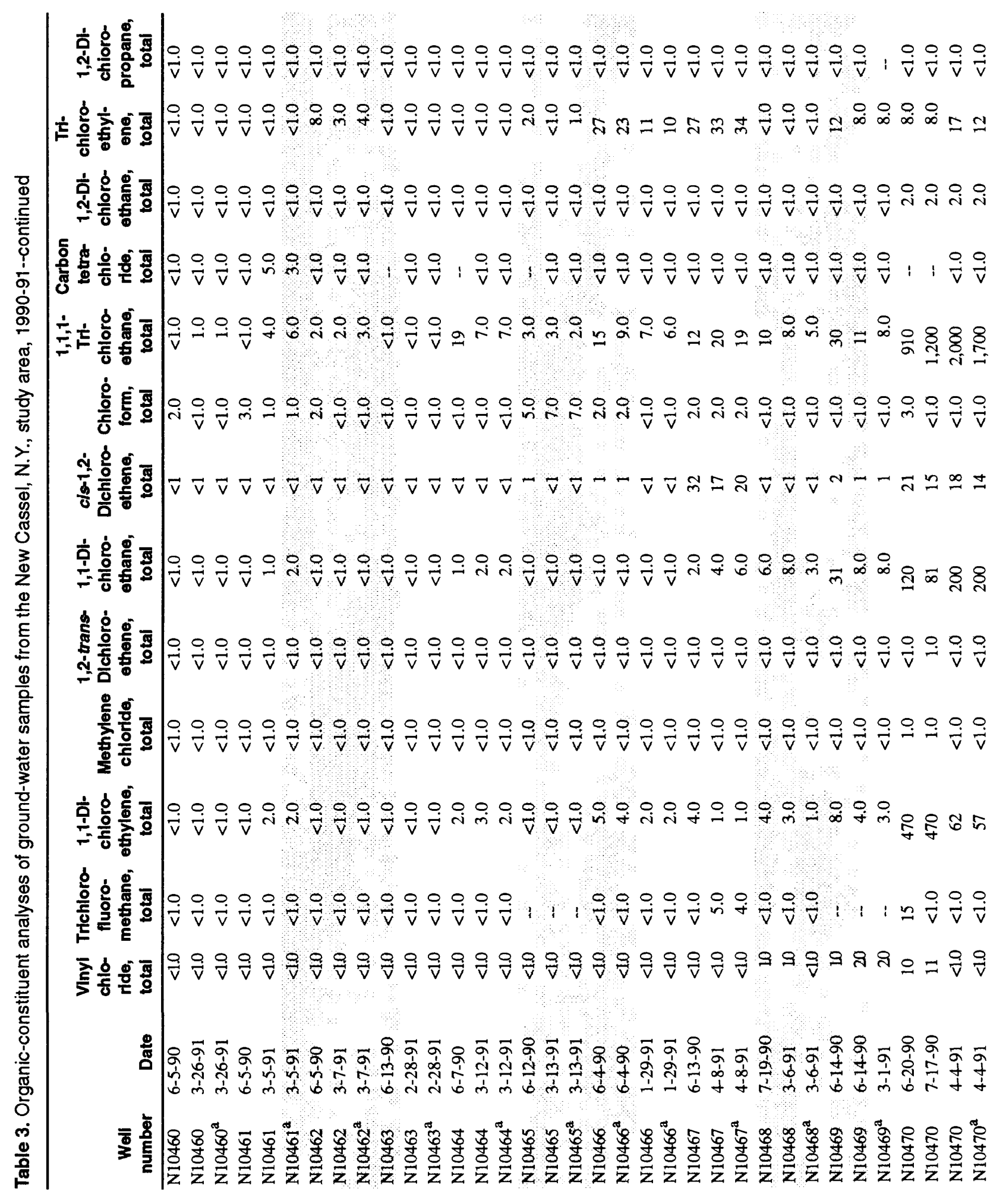




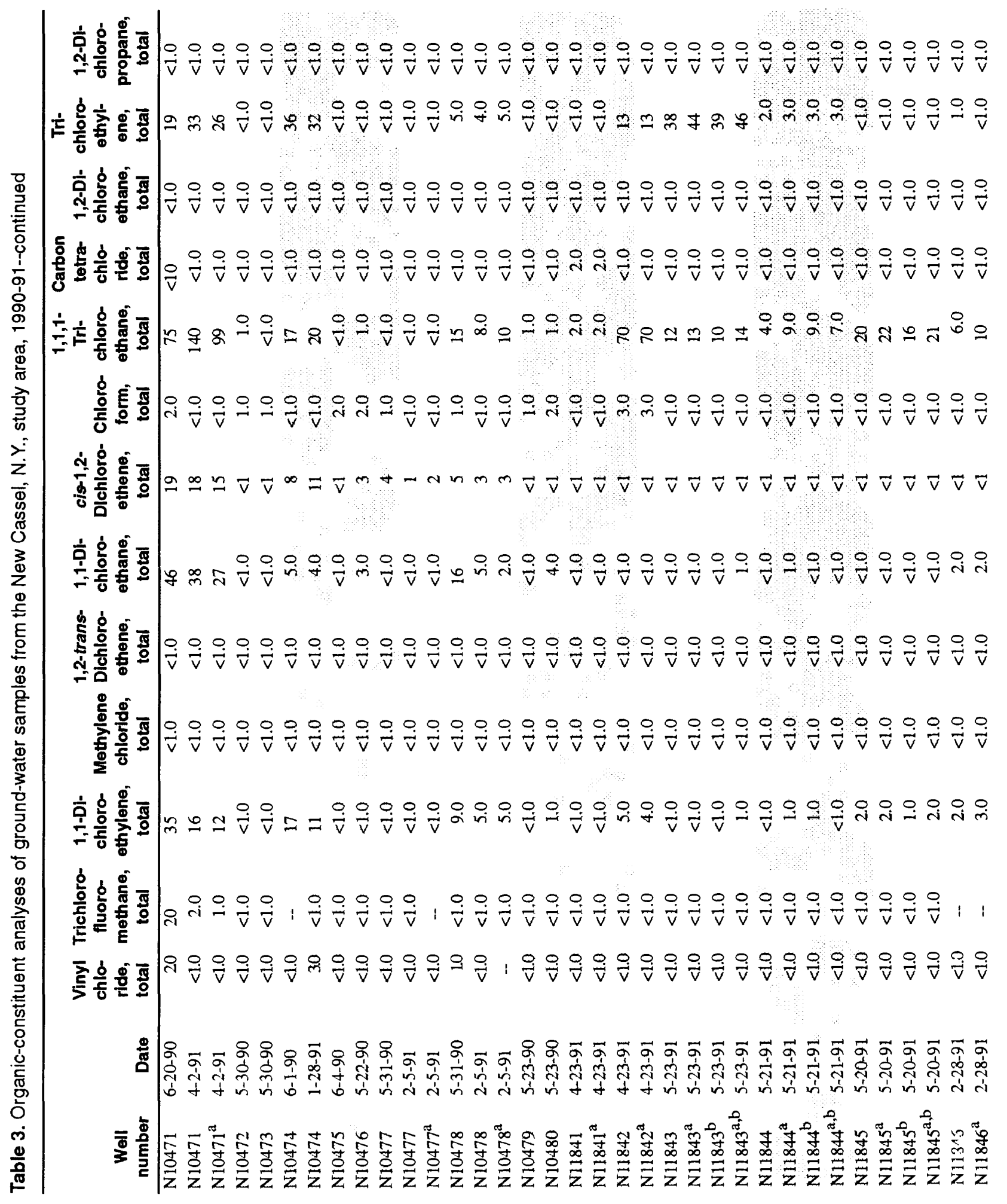




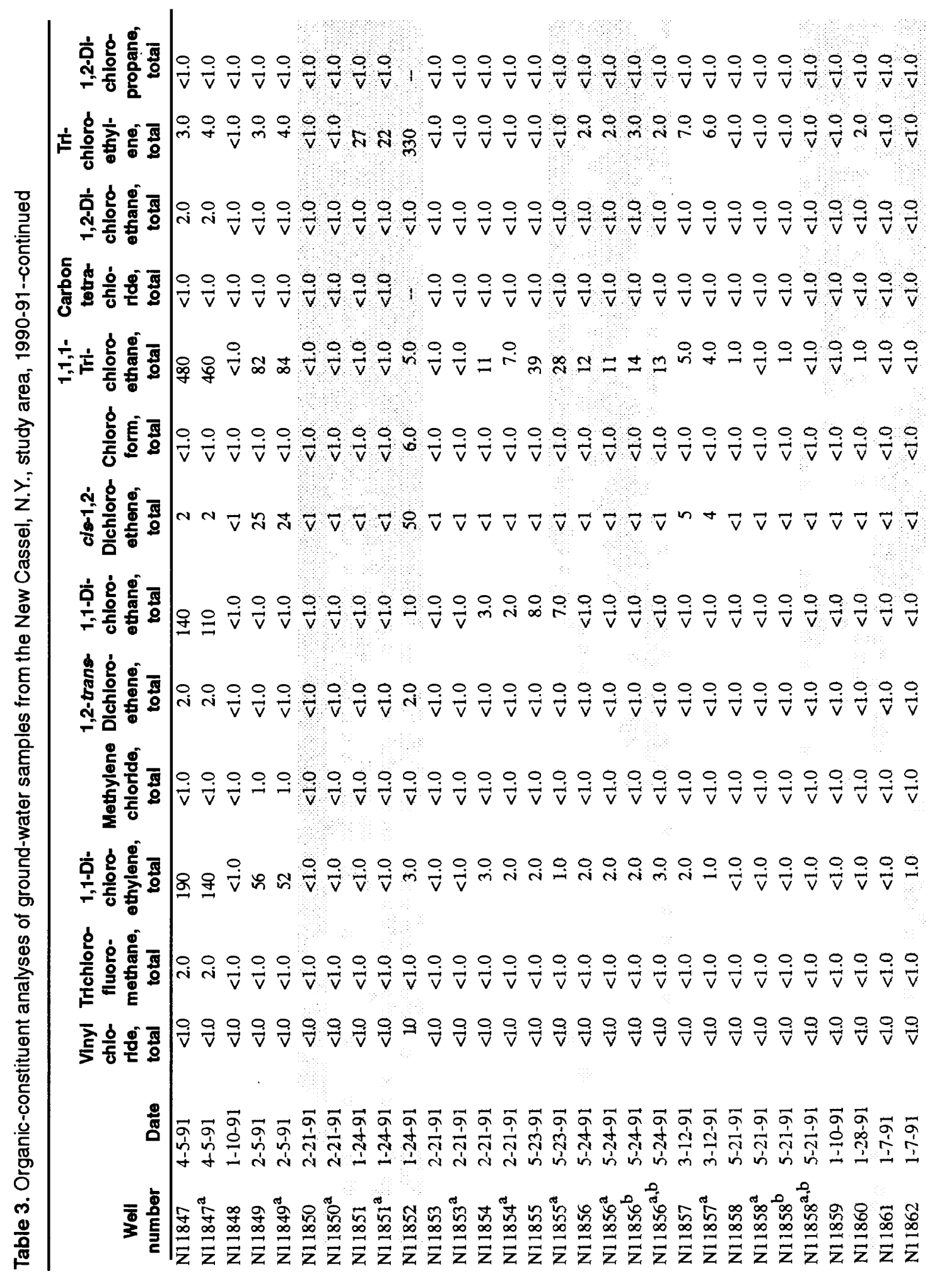




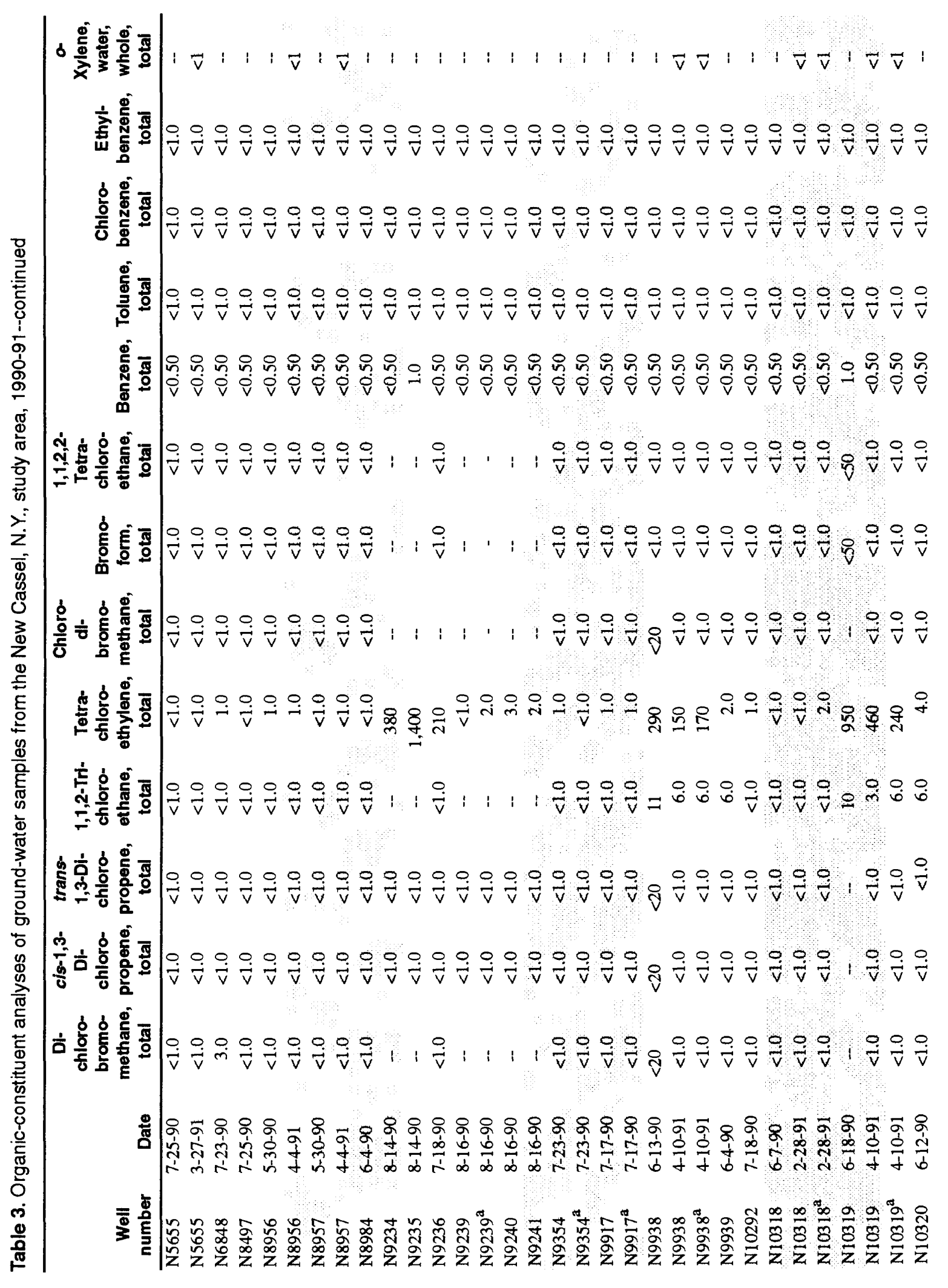




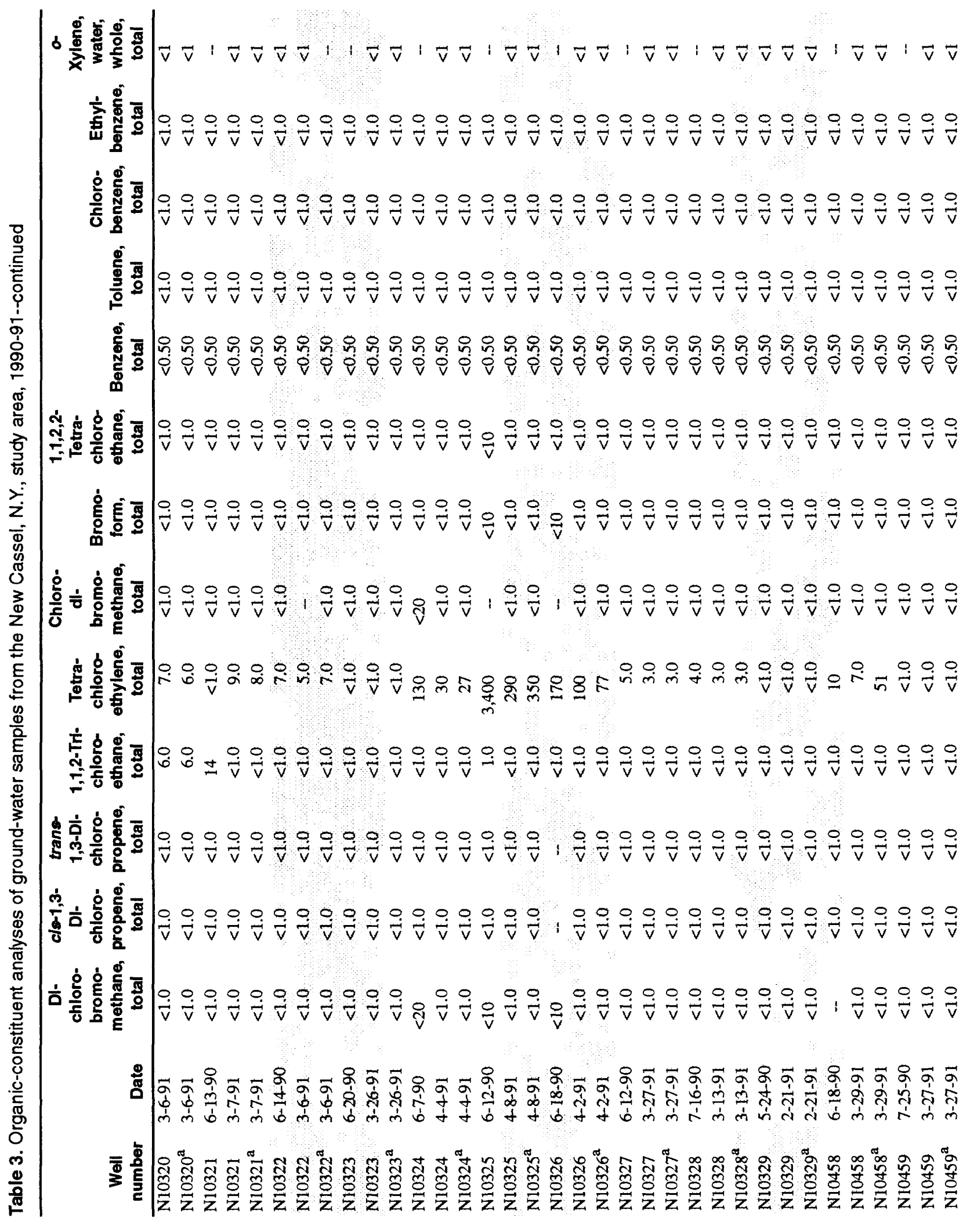




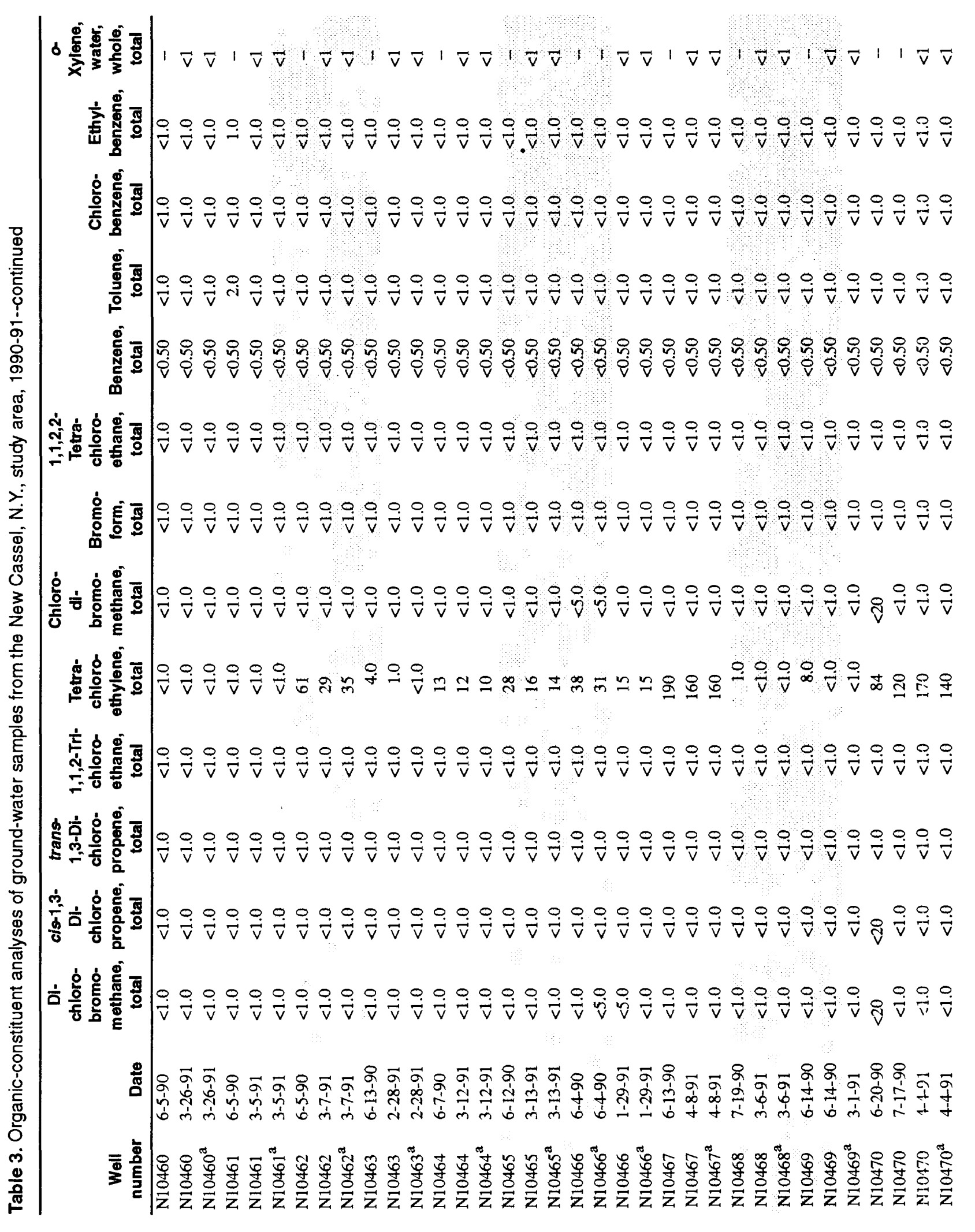




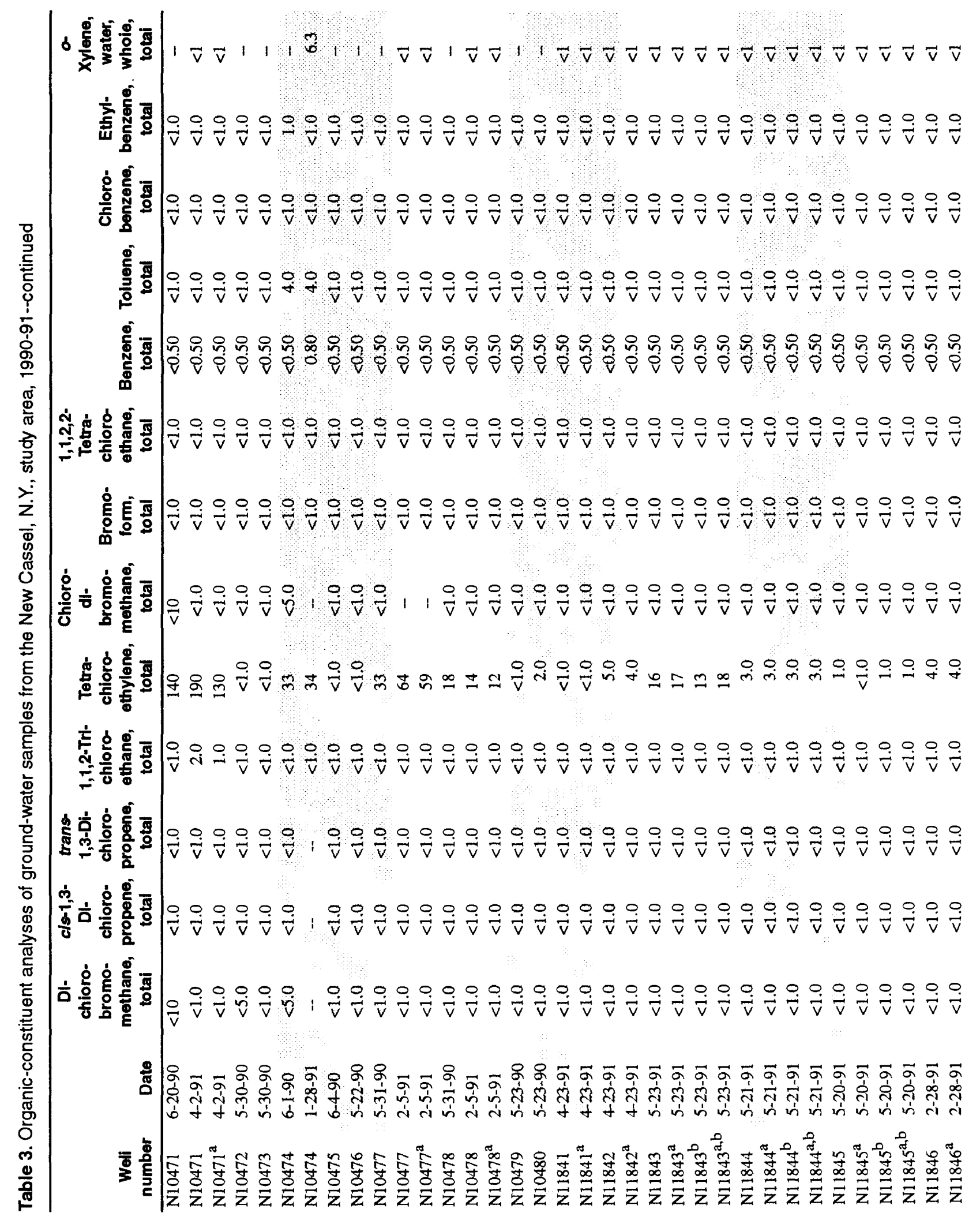




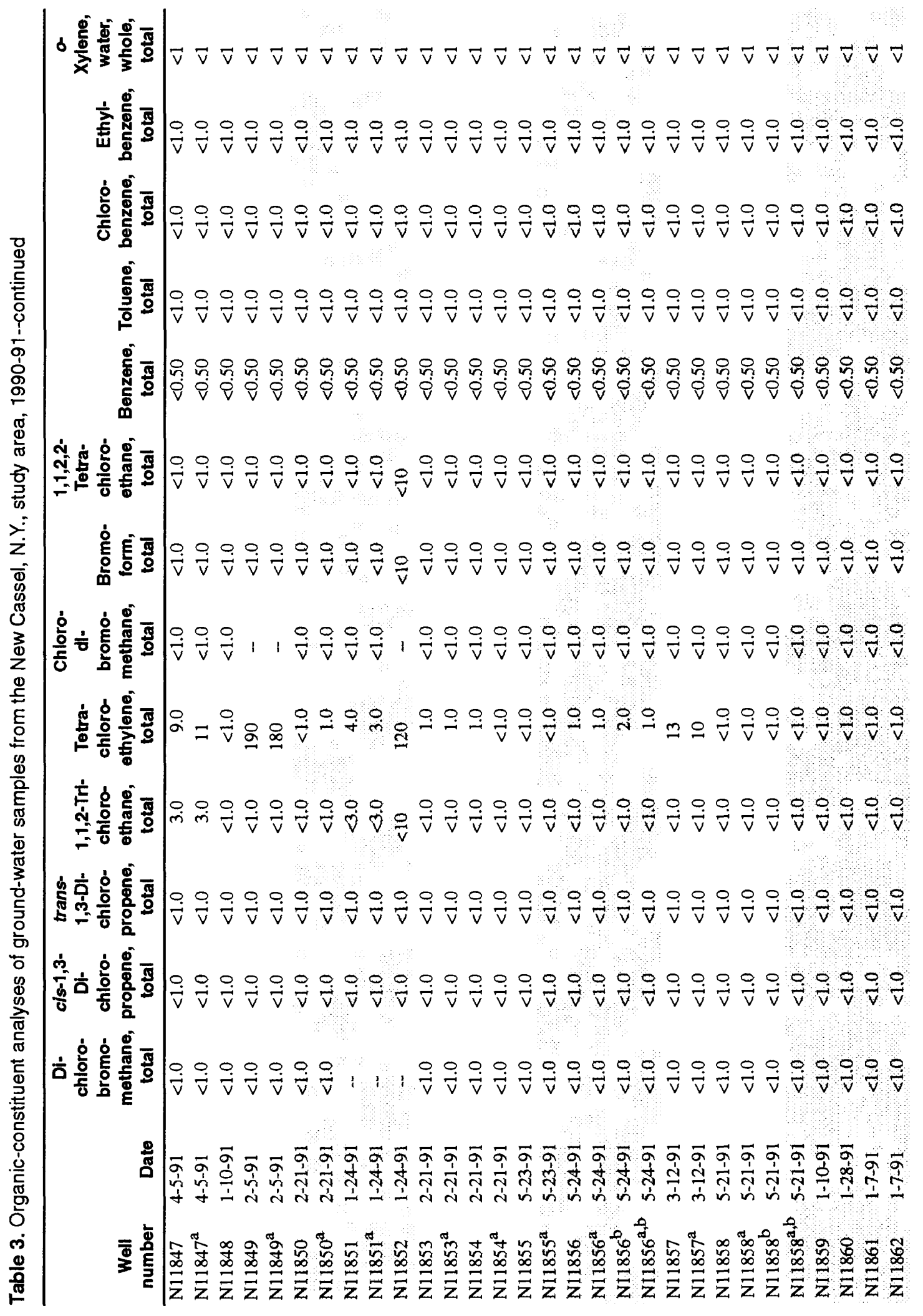




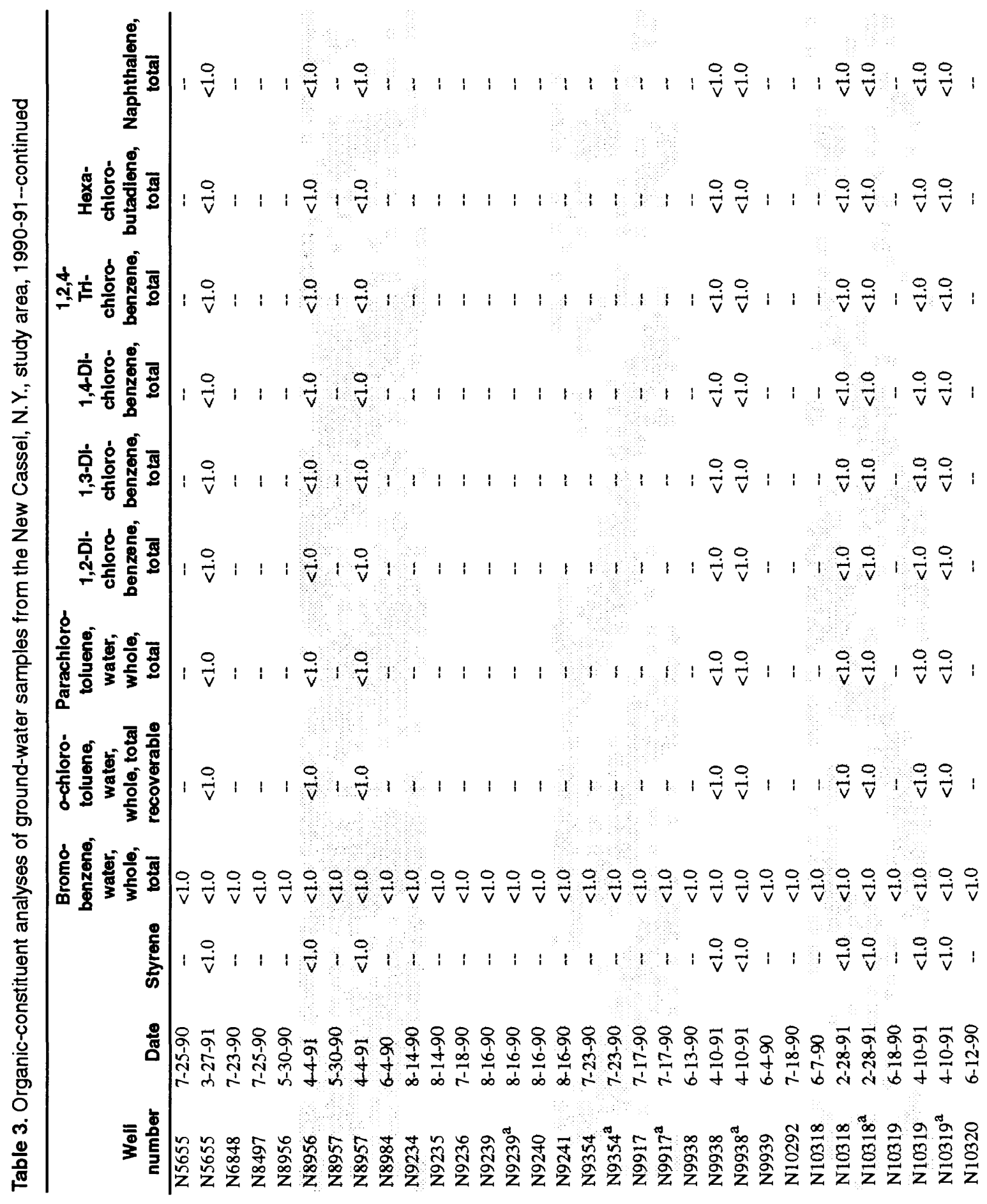




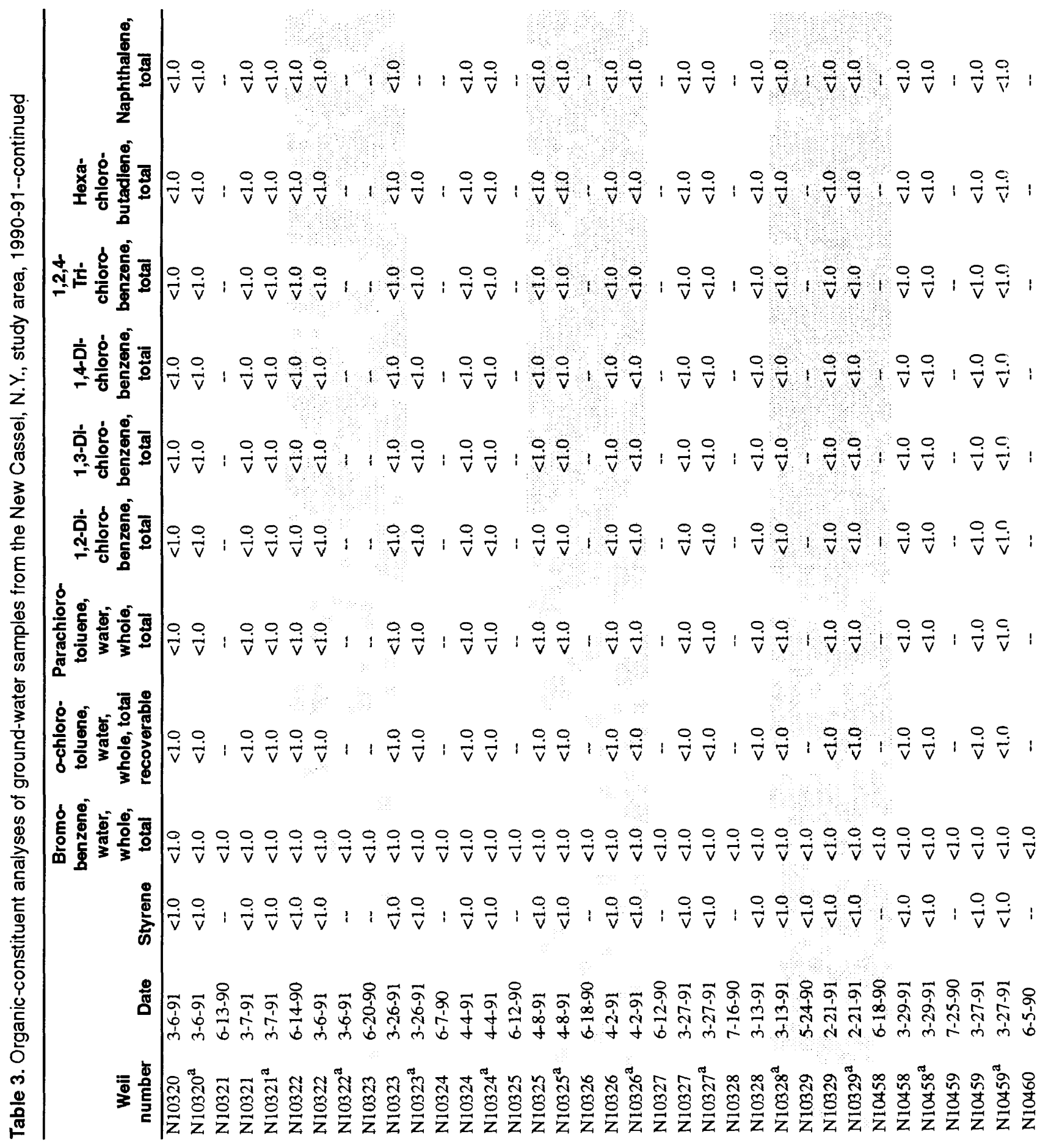




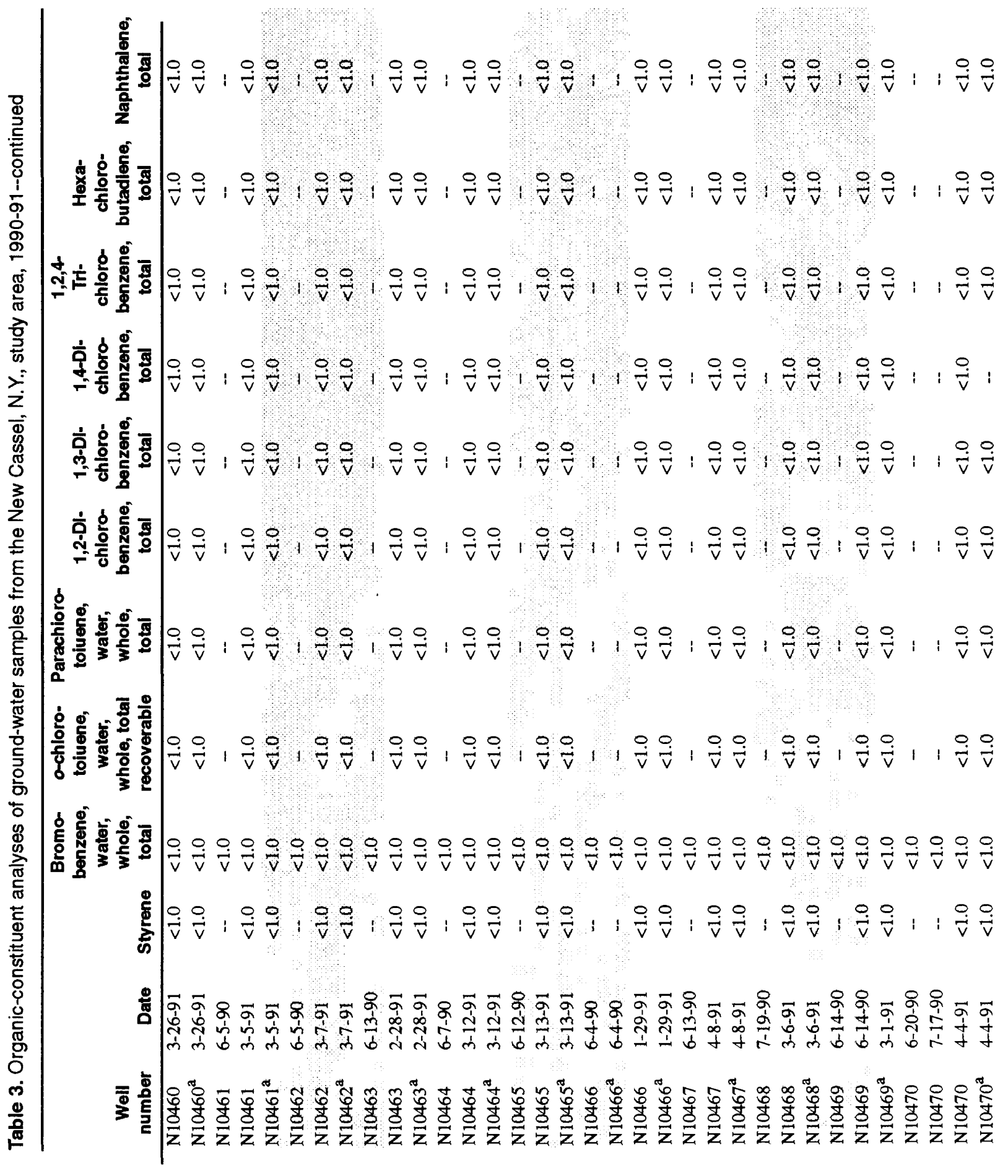




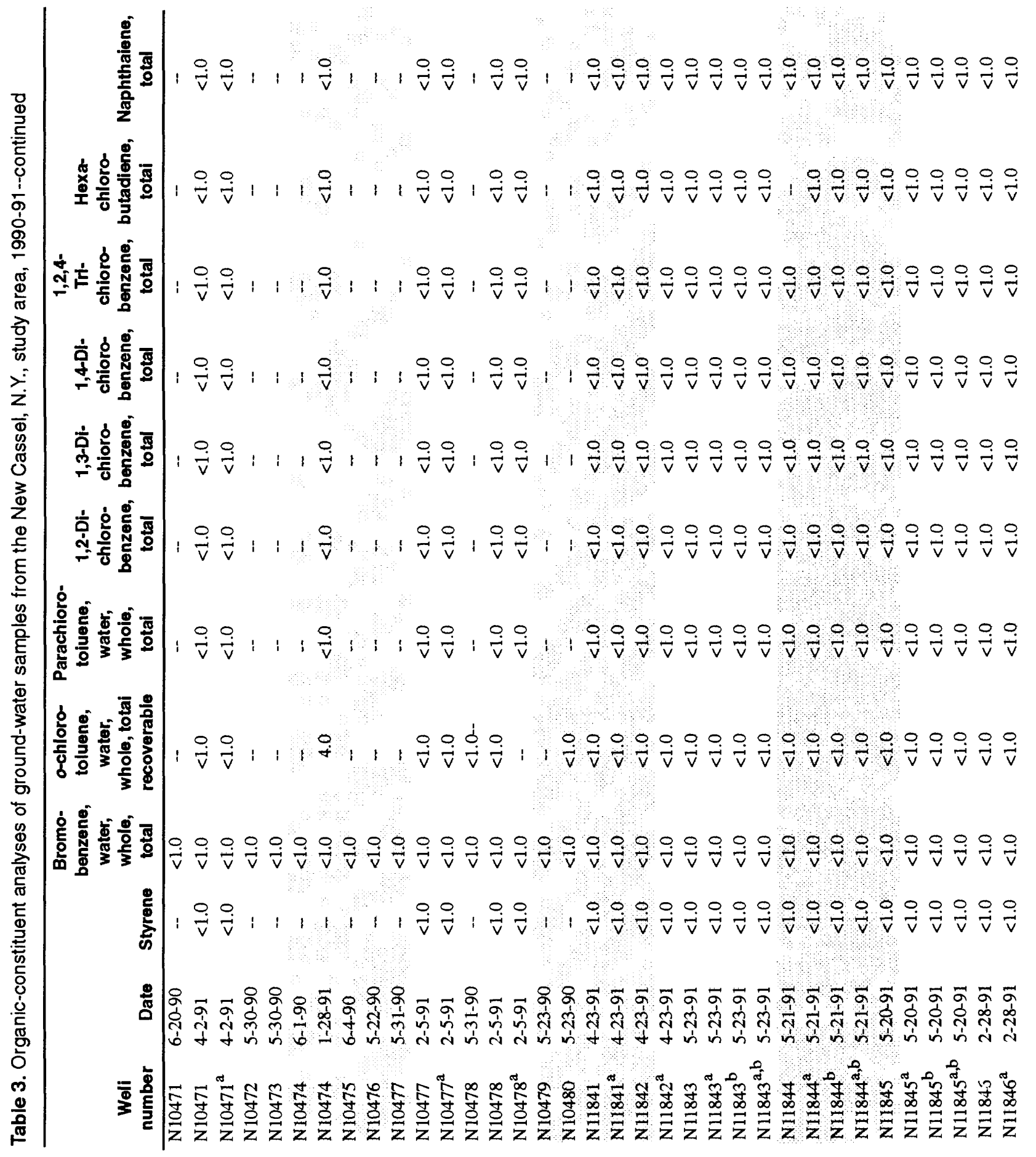




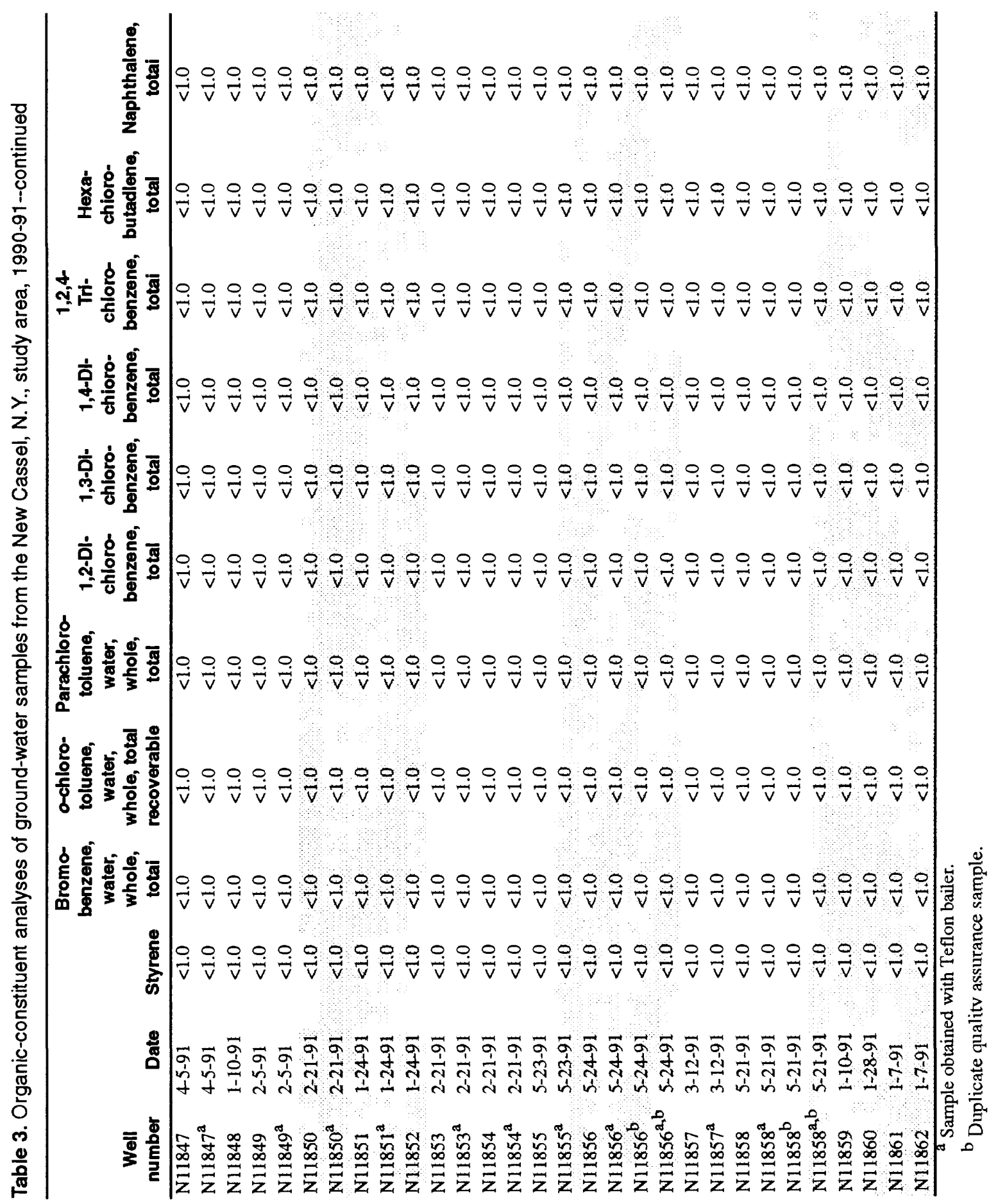


Table 4. Inorganic-constituent analyses of ground-water samples from the New Cassel, N.Y., study area, 1990-91 $[\mu \mathrm{S} / \mathrm{cm}$, microsiemens per centimeter at 25 degrees Celsius; deg $\mathrm{C}$, degrees Celsius; $\mathrm{mg} / \mathrm{L}$, milligrams per liter, $\mu \mathrm{g} / \mathrm{L}$, micrograms per liter --, no data available]

\begin{tabular}{|c|c|c|c|c|c|c|c|c|c|c|c|}
\hline $\begin{array}{c}\text { Well } \\
\text { number }\end{array}$ & Date & $\begin{array}{c}\text { Speciflc } \\
\text { conduct- } \\
\text { ance, } \\
\text { field } \\
(\mu S / c m)\end{array}$ & $\begin{array}{c}\text { Specific } \\
\text { conduct- } \\
\text { ance, } \\
\text { labora- } \\
\text { tory } \\
(\mu \mathrm{S} / \mathrm{cm})\end{array}$ & $\begin{array}{c}\text { pH } \\
\text { fleld } \\
\text { (stand- } \\
\text { ard } \\
\text { units) }\end{array}$ & $\begin{array}{l}\text { pH } \\
\text { labora- } \\
\text { tory } \\
\text { (stand- } \\
\text { ard } \\
\text { units) }\end{array}$ & $\begin{array}{c}\text { Temper- } \\
\text { ature } \\
\text { (deg C) }\end{array}$ & $\begin{array}{l}\text { Oxygen, } \\
\text { dis- } \\
\text { solved } \\
\text { (mgll) }\end{array}$ & $\begin{array}{l}\text { Calclum, } \\
\text { dis- } \\
\text { solved } \\
\text { (mg/l as } \\
\text { Ca) }\end{array}$ & $\begin{array}{l}\text { Magne- } \\
\text { sium, } \\
\text { dissolved } \\
\text { (mgll } \\
\text { as Mg) }\end{array}$ & $\begin{array}{l}\text { Sodium, } \\
\text { dls- } \\
\text { solved } \\
\text { (mg/L as } \\
\mathrm{Na} \text { ) }\end{array}$ & $\begin{array}{l}\text { Potas- } \\
\text { sium, } \\
\text { dissol ed } \\
\text { (mg/L } \\
\text { as K }\end{array}$ \\
\hline N5655 & $7-25-90$ & -- & 199 & 5.2 & 5.7 & 14.0 & -- & 10 & 3.3 & 21 & $\overline{1.3}$ \\
\hline N5655 & $3-26-91$ & 184 & - & 6.1 & 6.8 & 12.0 & - & 9.5 & 2.8 & 16 & 1.2 \\
\hline N6848 & $7-23-90$ & -- & 230 & 5.3 & 5.7 & 18.0 & -- & 18 & 3.7 & 16 & 3.6 \\
\hline N8497 & $7-25-90$ & - & 57 & 5.5 & 6.5 & 14.5 & -- & 3.0 & 1.2 & 5.0 & 0.6 \\
\hline N8956 & $5-30-90$ & -- & 78 & 5.7 & 6.5 & 11.5 & -- & 4.3 & 1.5 & 6.0 & 0.8 \\
\hline N8956 & 4-4-91 & 83 & 84 & 6.5 & 6.3 & 11.5 & - & 5.0 & 1.5 & 8.0 & 0.1 \\
\hline N8957 & $5-30-90$ & $\sim$ & 121 & 7.0 & 8.1 & 14.0 & - & 6.6 & 1.7 & 15 & 0.8 \\
\hline N8957 & $4-4-91$ & 49 & 44 & 5.4 & 6.2 & 12.5 & - & 2.3 & 0.9 & 4.0 & 0.4 \\
\hline N8984 & $6-4-90$ & - & 175 & 5.8 & 6.4 & 15.0 & - & 9.2 & 2.8 & 19 & 1.7 \\
\hline N9234 & $8-14-90$ & - & 250 & 5.1 & 5.5 & 15.5 & - & 11 & 4.5 & 28 & 1.8 \\
\hline N9235 & $8-14-90$ & - & 349 & 6.0 & 5.9 & 15.5 & - & 18 & 3.7 & 41 & 5.0 \\
\hline N9236 & $7-18-90$ & -- & 223 & 5.4 & 5.6 & 15.0 & -- & 15 & 2.7 & 20 & 2.9 \\
\hline N9239 & $8-16-90$ & -- & 89 & 5.6 & 5.5 & 14.0 & -- & 4.7 & 1.5 & 9.0 & 0.7 \\
\hline N9239 & $8-16-90$ & - & 89 & 5.6 & 5.6 & 14.0 & -- & 4.7 & 1.5 & 9.0 & 0.1 \\
\hline N9240 & $8-16-90$ & -- & 237 & 5.6 & 5.7 & 14.5 & - & 17 & 3.6 & 18 & 4.6 \\
\hline N9241 & $8-16-90$ & -- & 271 & 5.1 & 5.2 & 15.0 & -- & 17 & 3.1 & 26 & 3.9 \\
\hline N9354 & $7-23-90$ & - & 432 & 5.3 & 5.7 & 15.0 & - & 17 & 2.7 & 55 & 4.9 \\
\hline N9354 & $7-23-90$ & - & 436 & 5.3 & 5.7 & 15.0 & - & 16 & 2.6 & 56 & 4.8 \\
\hline N9917 & $7-17-90$ & - & 424 & 5.6 & 6.1 & 15.5 & - & 23 & 5.7 & 44 & 2.6 \\
\hline N9917 & $7-17-90$ & - & 417 & 5.6 & 6.9 & 15.5 & - & 23 & 5.8 & 43 & 2.6 \\
\hline N9938 & $6-13-90$ & -- & 321 & 4.8 & 5.4 & 17.0 & -- & 14 & 5.6 & 33 & 2.1 \\
\hline N9938 & $4-10-91$ & 369 & 502 & 5.0 & 5.4 & 17.0 & -- & 17 & 6.4 & 45 & 2.6 \\
\hline N9939 & $6-4-90$ & -- & 252 & 4.4 & 5.0 & 16.0 & -- & 15 & 3.8 & 21 & 5.0 \\
\hline N10292 & $7-18-90$ & -- & 323 & 5.1 & 5.2 & 15.5 & -- & 14 & 5.0 & 38 & 3.2 \\
\hline N10292 & $10-1-91$ & - & 162 & 5.6 & 5.4 & 15.5 & -- & - & -- & -- & -- \\
\hline $\mathrm{N} 10292$ & $6-10-91$ & 223 & 206 & 5.3 & 5.2 & 14.0 & 4.0 & + & - & - & - \\
\hline N10318 & $6-7-90$ & -- & 522 & 5.2 & 5.6 & 15.0 & - & 7.6 & 9.6 & 42 & 3.2 \\
\hline N10318 & $2-28-91$ & 286 & 288 & 5.1 & 5.9 & 14.0 & - & 26 & 6.3 & 17 & 2.3 \\
\hline N10319 & $6-18-90$ & -- & 733 & 5.8 & 5.6 & 16.0 & - & 49 & 7.3 & 94 & 4.9 \\
\hline N10319 & $4-10-91$ & 640 & 695 & 4.8 & 5.1 & 16.0 & - & 20 & 23 & 66 & 9.7 \\
\hline N10320 & $6-12-90$ & -- & 292 & 5.4 & 5.4 & 15.5 & - & 15 & 4.4 & 30 & 3.4 \\
\hline N10320 & $3-6-91$ & 416 & 430 & 4.9 & 5.8 & 15.0 & -- & 25 & 7.7 & 42 & 4.1 \\
\hline N10321 & $6-13-90$ & -- & 151 & 5.4 & 5.7 & 16.0 & -- & 16 & 2.1 & 9.0 & 3.7 \\
\hline N10321 & $3-7-91$ & 142 & 150 & 4.9 & 5.7 & 15.0 & -- & 9.8 & 2.2 & 11 & 3.2 \\
\hline N10322 & $6-14-90$ & - & 108 & 5.8 & 6.6 & 15.5 & -- & 4.5 & 1.9 & 13 & 0.4 \\
\hline N10322 & $3-6-91$ & 189 & 230 & 5.7 & 6.4 & 15.0 & - & 7.0 & 2.9 & 21 & 0.5 \\
\hline N10322 & $3-25-91$ & 439 & 471 & 5.4 & 5.9 & 14.5 & - & 54 & 6.4 & 13 & 3.6 \\
\hline N10323 & $6-20-90$ & - & 467 & 6.1 & 6.1 & 15.5 & - & 110 & 7.9 & 17 & 3.6 \\
\hline N10324 & $6-7-90$ & - & 287 & 5.5 & 5.8 & 15.5 & $\cdots$ & 19 & 3.3 & 26 & 4.9 \\
\hline N10324 & $4-3-91$ & 284 & 309 & 5.0 & 5.6 & 14.5 & - & 21 & 3.2 & 27 & 5.8 \\
\hline
\end{tabular}


Table 4. Inorganic-constituent analyses of ground-water samples from the New Cassel, N.Y., study area, 1990-91--continued

\begin{tabular}{|c|c|c|c|c|c|c|c|c|c|c|c|}
\hline $\begin{array}{c}\text { Well } \\
\text { number }\end{array}$ & Date & $\begin{array}{c}\text { Speciflc } \\
\text { conduct- } \\
\text { ance, } \\
\text { fleld } \\
(\mu \mathrm{S} / \mathrm{cm})\end{array}$ & $\begin{array}{c}\text { Speciflc } \\
\text { conduct- } \\
\text { ance, } \\
\text { labora- } \\
\text { tory } \\
(\mu \mathrm{S} / \mathrm{cm})\end{array}$ & $\begin{array}{c}\text { pH } \\
\text { fleld } \\
\text { (stand- } \\
\text { ard } \\
\text { units) }\end{array}$ & $\begin{array}{l}\text { pH } \\
\text { labora- } \\
\text { tory } \\
\text { (stand- } \\
\text { ard } \\
\text { units) }\end{array}$ & $\begin{array}{c}\text { Temper- } \\
\text { ature } \\
\text { (deg C) }\end{array}$ & $\begin{array}{l}\text { Oxygen, } \\
\text { dis- } \\
\text { solved } \\
\text { (mg/L) }\end{array}$ & $\begin{array}{l}\text { Calcium, } \\
\text { dis- } \\
\text { solved } \\
\text { (mg/l as } \\
\text { Ca) }\end{array}$ & $\begin{array}{l}\text { Magne- } \\
\text { slum, } \\
\text { dis- } \\
\text { solved } \\
\text { (mg/L } \\
\text { as Mg) }\end{array}$ & $\begin{array}{c}\text { Sodium, } \\
\text { dissolved } \\
(\mathrm{mg} / \mathrm{L} \text { as } \\
\mathrm{Na})\end{array}$ & $\begin{array}{l}\text { Potas- } \\
\text { sium, } \\
\text { dis- } \\
\text { solved } \\
\text { (mg/l } \\
\text { as K) }\end{array}$ \\
\hline N10325 & $6-12-90$ & - & 163 & 5.4 & 5.6 & 16.5 & -- & 11 & 2.4 & 13 & 1.6 \\
\hline N10325 & 4-8-91 & 125 & 125 & 5.7 & 5.8 & 17.5 & -- & 9.8 & 2.4 & 10 & 0.8 \\
\hline N10326 & $6-18-90$ & -- & 306 & 5.2 & 5.3 & 16.5 & -- & 15 & 4.2 & 31 & 12 \\
\hline N10326 & $4-2-91$ & 258 & 256 & 4.6 & 5.2 & 15.5 & -- & 11 & 3.1 & 29 & 5.1 \\
\hline N10327 & $6-12-90$ & -- & 392 & 4.0 & 4.6 & 16.5 & -- & 26 & 4.9 & 25 & 24 \\
\hline $\mathrm{N} 10327$ & $3-26-91$ & 444 & 430 & 4.8 & 5.4 & 15.5 & - & 38 & 6.2 & 31 & 10 \\
\hline $\mathrm{N} 10328$ & $7 \cdot 1690$ & - & 325 & 5.4 & 5.6 & 17.5 & - & 11 & 3.7 & 40 & 3.0 \\
\hline N10328 & $3-13-91$ & 277 & 285 & 5.0 & 58 & 15.5 & - & 11 & 3.8 & 33 & 2.9 \\
\hline $\mathrm{N} 10329$ & $5-24-90$ & - & 1,050 & 5.1 & 58 & 16.5 & - & 40 & 9.2 & 150 & 3.4 \\
\hline $\mathrm{N} 10329$ & $2-21-91$ & 1,410 & 1,450 & 5.1 & 5.6 & 16.0 & - & 50 & 13 & 220 & 3.8 \\
\hline N10458 & $6-18-90$ & -- & 533 & 5.1 & 5.6 & 15.0 & -- & 47 & 15 & 47 & 12 \\
\hline N10458 & $3-29-91$ & 524 & 539 & 5.0 & 5.6 & 16.0 & -. & 21 & 15 & 53 & 5.6 \\
\hline N10459 & $7-25-90$ & -- & 245 & 4.8 & 4.4 & 15.5 & -- & 16 & 4.3 & 15 & 4.2 \\
\hline N10459 & $3-26-91$ & 225 & 228 & 4.5 & 4.5 & 13.5 & - & 16 & 3.6 & 9.0 & 4.5 \\
\hline N10460 & $6-5-90$ & -- & 190 & 5.0 & 5.3 & 14.0 & -- & 10 & 2.8 & 17 & 2.8 \\
\hline Ni0460 & $3-25-91$ & 232 & 235 & 4.9 & 5,4 & 13.5 & - & 14 & 3.6 & 19 & 2.5 \\
\hline N10461 & $6-5-90$ & - & 287 & 4.9 & 5.1 & 15.0 & -. & 17 & 5.7 & 21 & 5.0 \\
\hline N10461 & $3-5-91$ & 324 & 280 & 4.7 & 5.8 & 14.5 & - & 19 & 6.0 & 31 . & 5.0 \\
\hline $\mathrm{N} 10462$ & $6-5-90$ & - & 288 & 5.5 & 5.9 & 15.0 & - & 23 & 5.2 & 23 & 3.5 \\
\hline N10462 & 3-7-91 & 297 & 325 & 5.4 & 6.1 & 14.5 & - & 22 & 6.9 & 18 & 3.7 \\
\hline N10463 & $6-13-90$ & -- & 305 & 5.1 & 5.4 & 15.0 & -- & 26 & 9.0 & 15 & 4.8 \\
\hline N10463 & $2-28-91$ & 353 & 355 & 5.0 & 5.6 & 13.5 & -- & 31 & 11 & 15 & 5.2 \\
\hline N10464 & $6-7-90$ & -- & 253 & 5.6 & 5.8 & 16.5 & - & 22 & 3.5 & 19 & 4.5 \\
\hline N10464 & $3-12-91$ & 257 & 263 & 5.3 & 6.0 & 15.0 & -- & 20 & 4.4 & 22 & 3.6 \\
\hline N10465 & $6-12-90$ & -- & 197 & 5.2 & 5.5 & 15.5 & -- & 9.3 & 3.1 & 19 & 2.5 \\
\hline N10465 & $3-13-91$ & 233 & 232 & 5.1 & 5.7 & 14.5 & -- & 13 & 4.0 & 21 & 2.4 \\
\hline N10466 & $6-4-90$ & - & 365 & 5.4 & 6.0 & 16.0 & - & 26 & 5.1 & 33 & 1.4 \\
\hline N10466 & $6-4-90$ & - & 374 & 5.4 & 6.0 & 16.0 & - & 29 & 4.9 & 33 & 1.4 \\
\hline N10466 & $1-29-91$ & 538 & 526 & 5.2 & 6.0 & 15.0 & - & 27 & 5.2 & 63 & 2.3 \\
\hline N10467 & $6-13-90$ & - & 417 & 5.2 & 5.5 & 15.5 & - & 61 & 9.2 & 10 & 2.3 \\
\hline N10467 & $4-8-91$ & 231 & 247 & 5.3 & 5.7 & 16.0 & -- & 23 & 8.2 & 8.0 & 1.7 \\
\hline N10468 & $7-19-90$ & -- & 498 & 4.2 & 4.6 & 16.0 & -- & 26 & 15 & 35 & 4.3 \\
\hline N10468 & $3-6-91$ & 379 & 389 & 4.0 & 4.7 & 14.0 & -- & 22 & 12 & 25 & 4.3 \\
\hline N10469 & $6-14-90$ & -- & 480 & 5.4 & 6.2 & 15.5 & -- & 26 & 4.6 & 57 & 1.4 \\
\hline N10469 & $3-1-91$ & 266 & 273 & 5.5 & 6.4 & 15.5 & - & 13 & 2.2 & 34 & 0.9 \\
\hline $\mathrm{N} 10470$ & $6-20-90$ & - & 381 & 5.2 & 5.5 & 16.0 & -. & 52 & 6.3 & 29 & 2.1 \\
\hline N10470 & $7+17-90$ & - & 332 & 5.2 & 5.9 & 16.5 & - & 27 & 5.5 & 25 & 2.0 \\
\hline $\mathrm{N} 10470$ & $4-3-91$ & 297 & 312 & 4.9 & 5.5 & 15.0 & -- & 24 & 6.1 & 23 & 2.2 \\
\hline $\mathrm{N} 10471$ & $6-20-90$ & - & 348 & 5.2 & 5.7 & 16.0 & -- & 27 & 5.9 & 27 & 4.6 \\
\hline N10471 & $4-2-91$ & 354 & 382 & 5.2 & 5.7 & 15.0 & - & 30 & 8.1 & 21 & 5.3 \\
\hline
\end{tabular}


Table 4. Inorganic-constituent analyses of ground-water samples from the New Cassel, N.Y. area, 1990-91--continued

\begin{tabular}{|c|c|c|c|c|c|c|c|c|c|c|c|}
\hline $\begin{array}{c}\text { Well } \\
\text { number }\end{array}$ & Date & $\begin{array}{c}\text { Specific } \\
\text { conduct- } \\
\text { ance, } \\
\text { fieid } \\
(\mu \mathrm{S} / \mathrm{cm})\end{array}$ & $\begin{array}{c}\text { Specific } \\
\text { conduct- } \\
\text { ance, } \\
\text { labora- } \\
\text { tory } \\
(\mu \mathrm{S} / \mathrm{cm})\end{array}$ & $\begin{array}{c}\text { pH } \\
\text { fleld } \\
\text { (stand- } \\
\text { ard } \\
\text { units) }\end{array}$ & $\begin{array}{l}\text { pH } \\
\text { labora- } \\
\text { tory } \\
\text { (stand- } \\
\text { ard } \\
\text { units) }\end{array}$ & $\begin{array}{c}\text { Temper- } \\
\text { ature } \\
\text { (deg C) }\end{array}$ & $\begin{array}{l}\text { Oxygen, } \\
\text { dis- } \\
\text { solved } \\
\text { (mg/L) }\end{array}$ & $\begin{array}{l}\text { Calcium, } \\
\text { dis- } \\
\text { solved } \\
\text { (mg/Las } \\
\text { Ca) }\end{array}$ & $\begin{array}{l}\text { Magne- } \\
\text { sium, } \\
\text { dis- } \\
\text { solved } \\
\text { (mg/L } \\
\text { as Mg) }\end{array}$ & $\begin{array}{l}\text { Sodium, } \\
\text { dis- } \\
\text { solved } \\
\text { (mg/l as } \\
\mathrm{Na} \text { ) }\end{array}$ & $\begin{array}{l}\text { Potas- } \\
\text { sium, } \\
\text { dissolved } \\
\text { (mg/L } \\
\text { as K) }\end{array}$ \\
\hline N10472 & $5-30-90$ & -- & 233 & 5.2 & 5.2 & 14.0 & - & 15 & 2.6 & 20 & 2.6 \\
\hline N10473 & $5-30-90$ & -- & 276 & 5.5 & 5.9 & 14.5 & - & 15 & 4.5 & 25 & 4.2 \\
\hline N10474 & $6-1-90$ & -- & 350 & 5.6 & 5.9 & 17.0 & -- & 15 & 5.9 & 36 & 3.9 \\
\hline N10474 & $1-28-91$ & 429 & 440 & 5.3 & 5.9 & 15.0 & -- & 20 & 7.7 & 51 & 4.7 \\
\hline N10475 & $6-4-90$ & -- & 94 & 5.1 & 5.9 & 16.0 & -- & 4.5 & 3.4 & 5.0 & 2.2 \\
\hline N10476 & $5-22-90$ & -- & 126 & 5.6 & 6.3 & 14.0 & - & 8.6 & 3.4 & 13 & 2.9 \\
\hline N10477 & $5-31-90$ & - & 661 & 4.4 & 4.2 & 16.5 & -- & 41 & 9.2 & 46 & 14 \\
\hline N10477 & $2-5-91$ & 522 & 499 & 3.6 & 4.1 & 16.5 & -- & 26 & 5.6 & 41 & 9.7 \\
\hline N10478 & $5-31-90$ & - & 304 & 4.7 & 5.3 & 15.0 & - & 15 & 6.0 & 27 & 3.9 \\
\hline N10478 & $2-5-91$ & 285 & 282 & 4.6 & 5.3 & 15.0 & $\cdots$ & 15 & 5.6 & 25 & 3.9 \\
\hline N10479 & $5-23-90$ & - & 249 & 5.5 & 6.2 & 13.5 & -- & 34 & 4.8 & 6.0 & 3.3 \\
\hline N10480 & $5-23-90$ & -- & 263 & 4.7 & 5.4 & 13.5 & -- & 17 & 3.3 & 21 & 5.9 \\
\hline N11841 & 4-23-91 & 143 & 140 & 5.3 & 6.5 & 16.5 & -- & 6.5 & 2.3 & 16 & 1.9 \\
\hline N11842 & $4-23-91$ & 451 & 461 & 5.4 & 5.9 & 16.5 & -- & 20 & 3.8 & 62 & 5.3 \\
\hline $\mathrm{N} 11843$ & $5-23-91$ & 271 & 246 & 5.5 & 6.0 & 16.5 & 6.2 & 28 & 6.4 & 11 & 3.1 \\
\hline N11843 & $5-23-91$ & 271 & 276 & 5.5 & 6.0 & 16.5 & 6.2 & 28 & 6.5 & 11 & 3.2 \\
\hline N11844 & $5-21-91$ & 224 & 207 & 5.3 & 6.2 & 18.0 & $\therefore$ & 7.8 & 3.9 & 21 & 2.9 \\
\hline N11844 & $5-21-91$ & 224 & 207 & 5.3 & 6.0 & 18.0 & - & 7.8 & 3.9 & 22 & 2.9 \\
\hline N11845 & $5-20-91$ & 320 & 323 & 4.6 & 5.2 & 17.0 & 3.8 & 20 & 5.2 & 20 & 8.3 \\
\hline N11846 & $2-28-91$ & 247 & 249 & 5.6 & 5.8 & 15.0 & - & 12 & 4.1 & 24 & 2.5 \\
\hline N11847 & $4-5-91$ & 421 & 454 & 5.6 & 6.3 & 15.0 & -- & 21 & 6.3 & 57 & 4.9 \\
\hline N11848 & $1-10-91$ & 169 & 161 & 5.7 & 6.1 & 14.5 & - & 4.8 & 1.2 & 25 & 1.5 \\
\hline N11849 & $2-5-91$ & 290 & 281 & 5.4 & 6.3 & 14.5 & - & 16 & 2.0 & 33 & 6.2 \\
\hline N11850 & $2-20-91$ & 182 & 192 & 5.5 & 6.0 & 15.0 & - & 17 & 2.2 & 15 & 1.5 \\
\hline N11851 & $1-24-91$ & 493 & 517 & 5.2 & 5.8 & 15.0 & -- & 41 & 3.4 & 49 & 4.1 \\
\hline N11852 & $1-24-91$ & 226 & 235 & 5.4 & 6.0 & 15.5 & - & 9.3 & 3.5 & 23 & 6.5 \\
\hline N11853 & $2-20-91$ & 250 & 261 & 4.8 & 5.3 & 16.0 & - & 23 & 5.5 & 14 & 4.6 \\
\hline N11854 & $2-21-91$ & 134 & 132 & 5.2 & 5.7 & 16.5 & - & 9.9 & 2.2 & 10 & 3.2 \\
\hline N11855 & $5-23-91$ & 351 & 429 & 5.1 & 5.6 & 18.0 & 2.5 & 16 & 3.6 & 45 & 9.7 \\
\hline N11856 & $5-24-91$ & 345 & 347 & 5.0 & 5.8 & 19.5 & 4.9 & 21 & 3.9 & 30 & 5.1 \\
\hline N11856 & $5-24-91$ & 345 & 342 & 5.0 & 6.0 & 19.5 & 4.9 & 21 & 4.0 & 30 & 5.0 \\
\hline N11857 & $3-12-91$ & 202 & 206 & 5.2 & 6.0 & 14.5 & -- & 11 & 4.2 & 20 & 1.5 \\
\hline N11858 & $5-21-91$ & 219 & 243 & 5.0 & 5.6 & 17.0 & -- & 13 & 2.4 & 23 & 1.9 \\
\hline N11858 & $5-21-91$ & 219 & 236 & 5.0 & 5.5 & 17.0 & - & 13 & 2.5 & 23 & 1.7 \\
\hline N11859 & $1-10-91$ & 99 & 100 & 5.0 & 5.7 & 15.0 & -- & 6.8 & 1.4 & 5.0 & 1.9 \\
\hline N11860 & $1-28-91$ & 165 & 167 & 5.1 & 5.7 & 15.0 & - & 14 & 2.8 & 11 & 2.4 \\
\hline N11861 & $1-7-91$ & 181 & 178 & 4.0 & 5.0 & 14.5 & - & 8.6 & 19 & 10 & 3.4 \\
\hline N11862 & $1-7-91$ & 201 & 205 & 4.7 & 5.4 & 14.0 & - & 10 & 3.1 & 13 & 2.9 \\
\hline
\end{tabular}


Table 4. Inorganic-constituent analyses of ground-water samples from the New Cassel, N.Y., study area, 1990-91--continued

\begin{tabular}{|c|c|c|c|c|c|c|c|c|c|c|c|}
\hline $\begin{array}{c}\text { Well } \\
\text { number }\end{array}$ & Date & $\begin{array}{c}\text { Alka- } \\
\text { IInlty, } \\
\text { labora- } \\
\text { tory } \\
\text { (mg/l as } \\
\mathrm{CaCO}_{3} \text { ) }\end{array}$ & $\begin{array}{l}\text { Carbon } \\
\text { dloxide, } \\
\text { dls- } \\
\text { solved } \\
\text { (mg/L as } \\
\mathrm{CO}_{2} \text { ) }\end{array}$ & $\begin{array}{l}\text { Sulfate, } \\
\text { dls- } \\
\text { solved } \\
\text { (mgllas } \\
\left.\mathrm{SO}_{4}\right)\end{array}$ & $\begin{array}{l}\text { Chlo- } \\
\text { rde, } \\
\text { dls- } \\
\text { solved } \\
\text { (mg/l as } \\
\text { Cl) }\end{array}$ & $\begin{array}{l}\text { Fluoride, } \\
\text { dls- } \\
\text { solved } \\
\text { (mg/L } \\
\text { as F) }\end{array}$ & $\begin{array}{l}\text { Sillca, } \\
\text { dls- } \\
\text { solved } \\
\left(\mathrm{mg}^{\prime} \mathrm{L} \mathrm{as}\right. \\
\left.\mathrm{SIO}_{2}\right)\end{array}$ & $\begin{array}{l}\text { Nitrogen, } \\
\text { nltrate, } \\
\text { dls- } \\
\text { solved } \\
\text { (mg/L as } \\
\text { N) }\end{array}$ & $\begin{array}{l}\text { Nitrogen, } \\
\text { nitrite, } \\
\text { dissolved } \\
\text { (mg/l as } \\
\text { N) }\end{array}$ & $\begin{array}{l}\text { Nitrogen, } \\
\text { ammonla, } \\
\text { dissolved } \\
\text { (mg/L as } \\
\mathrm{N})\end{array}$ & $\begin{array}{c}\text { A rsenlc, } \\
\text { dls- } \\
\text { solved } \\
(\mu g / l \text { as } \\
\text { As) }\end{array}$ \\
\hline N5655 & $7-25-90$ & 10 & -- & $<5.0$ & 30 & $<0.20$ & 8.1 & 8.0 & $<0.01$ & $<.02$ & $<5$ \\
\hline N5655 & $3-26-91$ & 17 & -- & $<5.0$ & 28 & $<0.20$ & 9.0 & 7.0 & .02 & $<.02$ & $<5$ \\
\hline N6848 & $7-23-90$ & 7.0 & 27 & 33 & 19 & $<0.20$ & 8.3 & 6.6 & .01 & $<.02$ & $<5$ \\
\hline N8497 & $7-25-90$ & 7.0 & -. & $<5.0$ & 4.0 & $<0.20$ & 7.5 & 2.9 & $<.01$ & $<0.02$ & $<5$ \\
\hline N8956 & $5-30-90$ & 7.0 & 4.0 & 5.0 & 5.3 & $<0.20$ & 9.2 & 3.6 & .02 & $<0.02$ & $<5$ \\
\hline N8956 & $4-4-91$ & 10 & $\cdots$ & $<5.0$ & 7.2 & $<0.20$ & 9.3 & 4.1 &.- & $<.02$ & $<5$ \\
\hline N8957 & $5-30-90$ & 31 & 1.0 & $<5.0$ & 5.4 & $<0.20$ & 8.0 & 3.5 & .03 & $<.02$ & $<5$ \\
\hline N8957 & $4-4-91$ & 7.0 & - & $<5.0$ & 3.6 & $<0.20$ & 8.7 & 1.3 & $\therefore$ & $<0.02$ & $<5$ \\
\hline N8984 & 6.490 & 27 & 21 & 16 & 17 & $<0.20$ & 4.2 & 1.9 & .01 & $<.02$ & $<5$ \\
\hline N9234 & $8-1490$ & 9.0 & - & 11 & 37 & $<0.20$ & 9.6 & 9.2 & $<.01$ & $<.02$ & $<5$ \\
\hline N9235 & $8-14-90$ & 33 & - & 23 & 38 & $<0.20$ & 5.2 & 3.6 & .04 & .03 & $<5$ \\
\hline N9236 & $7-18-90$ & 7.0 & -- & 21 & 32 & $<0.20$ & 9.1 & 3.9 & $<.01$ & $<.02$ & $<5$ \\
\hline N9239 & $8-16-90$ & 4.0 & -- & $<5.0$ & 9.0 & $<0.20$ & 7.0 & 5.6 & $<.01$ & $<.02$ & $<5$ \\
\hline N9239 & $8-16-90$ & 5.0 & -- & $<5.0$ & 9.8 & $<0.20$ & 7.0 & 5.8 & $<.01$ & $<.02$ & $<5$ \\
\hline N9240 & $8-16-90$ & 10 & -- & 26 & 25 & $<0.20$ & 9.7 & 7.2 & $<.01$ & $<.02$ & $<5$ \\
\hline $\mathrm{N} 9241$ & $8-16-90$ & 30 & - & 32 & 42 & $<0.20$ & 10 & 5.1 & 05 & $<.02$ & $<5$ \\
\hline N9354 & $7-23.90$ & 16 & 62 & 36 & 74 & $<0.20$ & 13 & 7.3 & 02 & 03 & $<5$ \\
\hline N9354 & $7-23-90$ & 16 & - & 34 & 73 & $<0.20$ & 13 & 8.0 & 002 & .03 & $<5$ \\
\hline N9917 & $7-17-90$ & 28 & - & 18 & 84 & $<0.20$ & 5.9 & 54 & 02 & $<02$ & $<5$ \\
\hline N9917 & $7-17-90$ & 28 & - & 18 & 83 & $<0.20$ & 5.9 & 3.6 & $<.01$ & $<.02$ & $<5$ \\
\hline N9938 & $6-13-90$ & 9.0 & -- & 36 & 51 & $<0.20$ & 8.6 & 4.3 & $<.01$ & .11 & $<5$ \\
\hline N9938 & $4-10-91$ & 8.0 & -- & 28 & 84 & $<0.20$ & 9.0 & 3.9 & - & 0.20 & $<5$ \\
\hline N9939 & $6-4-90$ & 3.0 & 58 & 23 & 26 & $<0.20$ & 10 & 9.9 & .02 & $<.02$ & $<5$ \\
\hline N10292 & $7-18-90$ & 5.0 & -- & 35 & 49 & $<0.20$ & 6.9 & .46 & $<.01$ & $<.02$ & $<5$ \\
\hline N10292 & $10-1-91$ & -- & -- & - & 7.5 & -- & -- & - & - & -- & -- \\
\hline $\mathrm{N} 10292$ & $6-10-91$ & - & - & - & 17 & - & - & - & - & $-\infty$ & - \\
\hline $\mathrm{N} 10318$ & 67,90 & 22 & 107 & 60 & 80 & $<0.20$ & 6.9 & 6.4 & 05 & $<.02$ & $<5$ \\
\hline $\mathrm{N} 10318$ & $2-28-91$ & 28 & - & 47 & 27 & $<0.20$ & 7.0 & 2.5 & - & $<.02$ & $<5$ \\
\hline$N 10319$ & $6-18-90$ & 19 & 93 & 53 & 120 & $<0.20$ & 8.5 & 14 & $<.01$ & $<.02$ & $<5$ \\
\hline $\mathrm{N} 10319$ & 41091 & 8.0 & - & 61 & 72 & $<0.20$ & 16 & 37 & - & .46 & $<5$ \\
\hline N10320 & $6-12-90$ & 19 & -- & 40 & 33 & $<0.20$ & 8.0 & 5.1 & .01 & $<.02$ & $<5$ \\
\hline N10320 & $3-6-91$ & 20 & -- & 54 & 64 & $<0.20$ & 7.7 & 5.9 & $<.01$ & $<.02$ & $<5$ \\
\hline N10321 & $6-13-90$ & 12 & -- & 15 & 12 & $<0.20$ & 9.0 & 4.6 & $<.01$ & $<.02$ & $<5$ \\
\hline N10321 & $3-7-91$ & 7.0 & -- & 24 & 10 & $<0.20$ & 11 & 3.9 & .02 & $<.02$ & $<5$ \\
\hline N10322 & $6-14-90$ & 23 & 11 & 7.0 & 12 & $<0.20$ & 4.2 & .67 & $<.01$ & $<.02$ & $<5$ \\
\hline $\mathrm{N} 10322$ & $3-6-91$ & 22 & - & 51 & 24 & $<0.20$ & 12 & .86 & $<.01$ & 03 & $<5$ \\
\hline $\mathrm{N} 10322$ & $325-91$ & 17 & - & 45 & 24 & - & 8.5 & 29 & - & $<.02$ & $<5$ \\
\hline $\mathrm{N} 10323$ & $6-20-90$ & 24 & 37 & 58 & 31 & $<0.20$ & 7.8 & 19 & 07 & $<.02$ & $<5$ \\
\hline N10324 & $6.7-90$ & 20 & 61 & 40 & 33 & $<0.20$ & 6.7 & 5.0 & .02 & $<.02$ & $<5$ \\
\hline $\mathrm{N} 10324$ & $4-3-91$ & 13 & - & 30 & 41 & $<0.20$ & 79 & 6.7 & - & $<.02$ & $<5$ \\
\hline
\end{tabular}


Table 4. Inorganic-constituent analyses of ground-water samples from the New Cassel, N.Y., study area, 1990-91--continued

\begin{tabular}{|c|c|c|c|c|c|c|c|c|c|c|c|}
\hline $\begin{array}{c}\text { Weil } \\
\text { number }\end{array}$ & Date & $\begin{array}{c}\text { Alka- } \\
\text { linity, } \\
\text { labora- } \\
\text { tory } \\
\text { (mg/L as } \\
\left.\mathrm{CaCO}_{3}\right)\end{array}$ & $\begin{array}{l}\text { Carbon } \\
\text { dioxide, } \\
\text { dls- } \\
\text { solved } \\
(\mathrm{mg} / \mathrm{L} \text { as } \\
\left.\mathrm{CO}_{2}\right)\end{array}$ & $\begin{array}{l}\text { Sulfate, } \\
\text { dis- } \\
\text { solved } \\
\left(\mathrm{mg}^{\prime} \text { Las }\right. \\
\left.\mathrm{SO}_{4}\right)\end{array}$ & $\begin{array}{l}\text { Chlo- } \\
\text { ride, } \\
\text { dis- } \\
\text { solved } \\
\text { (mg/l as } \\
\text { Cl) }\end{array}$ & $\begin{array}{l}\text { Fluoride, } \\
\text { dis- } \\
\text { solved } \\
\text { (mglL } \\
\text { as F) }\end{array}$ & $\begin{array}{l}\text { Silica, } \\
\text { dls- } \\
\text { solved } \\
\text { (mg/L as } \\
\left.\mathrm{SiO}_{2}\right)\end{array}$ & $\begin{array}{l}\text { Nitrogen, } \\
\text { nitrate, } \\
\text { dis- } \\
\text { solved } \\
\text { (mg/l as } \\
\text { N) }\end{array}$ & $\begin{array}{l}\text { Nitrogen, } \\
\text { nitrite, } \\
\text { dissolved } \\
\text { (mg/l as } \\
\text { N) }\end{array}$ & $\begin{array}{l}\text { Nitrogen, } \\
\text { ammonla, } \\
\text { dissolved } \\
\text { (mg/L as } \\
\mathrm{N})\end{array}$ & $\begin{array}{c}\text { Arseric, } \\
\text { dis: } \\
\text { solved } \\
(\mu \mathrm{g} / \mathrm{L} \text { as } \\
\text { As) }\end{array}$ \\
\hline N10325 & $6-12-90$ & 10 & -- & 27 & 13 & $<0.20$ & 9.9 & 3.2 & 0.01 & $<0.02$ & $<5$ \\
\hline N10325 & $4-8-91$ & 12 & -- & 24 & 5.4 & $<0.20$ & 7.5 & 2.1 & $<.01$ & $<.02$ & $<5$ \\
\hline N10326 & $6-18-90$ & 7.0 & 68 & 36 & 41 & $<0.20$ & 12 & 7.1 & .07 & $<.02$ & $<5$ \\
\hline N10326 & $4-2-91$ & 5.0 & -- & 27 & 33 & $<0.20$ & 12 & 6.1 & -- & $<.02$ & $<5$ \\
\hline N10327 & $6-12-90$ & 2.0 & -- & 40 & 29 & 0.32 & 14 & 22 & .01 & $<.02$ & $<5$ \\
\hline N10327 & $3-26-91$ & 8.0 & - & 62 & 41 & 0.30 & 12 & 17 & .01 & $<.02$ & $<5$ \\
\hline N10328 & $7-16-90$ & 12 & -- & 28. & 51 & $<0.20$ & $7: 1$ & 2.8 & $<.01$ & $<.02$ & $<5$ \\
\hline N10328 & $3-13-91$ & 13 & - & 23 & 53 & $<0.20$ & 7.4 & 3.3 & $<.01$ & $<.02$ & $<5$ \\
\hline N10329 & $5-24-90$ & 9.0 & 28 & 55 & 280 & $<0.20$ & 6.3 & 2.5 & $<.01$ & $<.02$ & $<5$ \\
\hline N10329 & $2-21-91$ & 8.0 & - & 68 & 390 & $<0.20$ & 7.5 & 3.5 & - & $<.02$ & $<5$ \\
\hline N10458 & $6-18-90$ & 16 & 78 & 50 & 70 & $<0.20$ & 13 & 20 & .65 & .79 & $<5$ \\
\hline N10458 & $3-29-91$ & 16 & -- & 38 & 17 & $<0.20$ & 11 & 27 & -- & .56 & $<5$ \\
\hline N10459 & $7-25-90$ & 1.0 & -- & 43 & 15 & $<0.20$ & 11 & 6.6 & $<.01$ & $<.02$ & $<5$ \\
\hline N10459 & $3-26-91$ & 1.0 & -- & 35 & 12 & $<0.20$ & 13 & 8.2 & .02 & $<.02$ & $<5$ \\
\hline N10460 & $6-5-90$ & 5.0 & 49 & 27 & 24 & $<0.20$ & 10 & 1.8 & .01 & $<.02$ & $<5$ \\
\hline N10460 & $3-25-91$ & 6.0 & - & 28 & 38 & - & 11 & 2.3 & - & $<.02$ & $<5$ \\
\hline N10461 & $6-5-90$ & 4.0 & 62 & 36 & 37 & $<0.20$ & 13 & 6.1 & .02 & $<.02$ & $<5$ \\
\hline N10461 & $3-5-91$ & 5.0 & - & 12 & 26 & $<0.20$ & 5.1 & 10 & .02 & $<.02$ & $<5$ \\
\hline N10462 & $6-5-90$ & 16 & 39 & 35 & 37 & $<0.20$ & 6.5 & 4.5 & .03 & $<.02$ & $<5$ \\
\hline N10462 & $3-7-91$ & 16 & - & 39 & 43 & $<0.20$ & 7.3 & 5.8 & $<.01$ & $<.02$ & $<5$ \\
\hline N10463 & $6-13-90$ & 15 & -- & 76 & 19 & $<0.20$ & 8.0 & 2.7 & .01 & $<.02$ & $<5$ \\
\hline N10463 & $2-28-91$ & 16 & -- & 75 & 23 & $<0.20$ & 6.2 & 2.0 & -- & $<.02$ & $<5$ \\
\hline N10464 & $6-7-90$ & 31 & 95 & 22 & 38 & $<0.20$ & 9.0 & 4.4 & .07 & $<.02$ & $<5$ \\
\hline N10464 & $3-12-91$ & 34 & -- & 29 & 23 & $<0.20$ & 9.7 & 5.2 & .02 & $<.02$ & $<5$ \\
\hline N10465 & $6-12-90$ & 13 & -- & 20 & 27 & $<0.20$ & 6.5 & 3.8 & $<0.01$ & $<.02$ & $<5$ \\
\hline N10465 & 3-13-91 & 14 & -- & 31 & 33 & $<0.20$ & 5.6 & 3.1 & $<.01$ & $<.02$ & $<5$ \\
\hline N10466 & $6-4-90$ & 18 & 35 & 22 & 60 & $<0.20$ & 3.8 & 7.6 & .02 & $<.02$ & $<5$ \\
\hline N10466 & $6-4-90$ & 18 & 35 & 22 & 61 & $<0.20$ & 3.8 & 7.7 & .02 & $<0.02$ & $<5$ \\
\hline N10466 & $1-29-91$ & 16 & - & 44 & 99 & $<0.20$ & 5.0 & 5.8 & $<.01$ & .02 & $<5$ \\
\hline N10467 & $6-13-90$ & 20 & - & 68 & 12 & 1.1 & 9.3 & 8.4 & $<.01$ & .77 & $<5$ \\
\hline N10467 & $4-8-91$ & 19 & -- & 51 & 8.6 & 0.72 & 8.2 & 4.9 & .02 & .32 & $<5$ \\
\hline N10468 & $7-19-90$ & 1.0 & -- & 52 & 35 & 0.28 & 10 & 29 & .04 & 1.1 & $<5$ \\
\hline N10468 & $3-6-91$ & 2.0 & -. & 58 & 63 & $<0.20$ & 7.8 & 18 & $<.01$ & .49 & $<5$ \\
\hline N10469 & $6-14-90$ & 32 & 39 & 28 & 98 & $<0.20$ & 5.6 & 1.5 & $<.01$ & $<0.02$ & $<5$ \\
\hline N10469 & $3-1-91$ & 23 & -- & 22 & 47 & -- & 5.6 & 1.3 & $<.01$ & $<.02$ & $<5$ \\
\hline N10470 & $6-20-90$ & 16 & 98 & 62 & 42 & 0.81 & 7.4 & 5.1 & .03 & $<.02$ & $<5$ \\
\hline N10470 & $7-17-90$ & 19 & -- & 53 & 36 & 0.64 & 7.4 & 4.7 & 0.01 & $<.02$ & $<5$ \\
\hline N10470 & $4-3-91$ & 9.0 & -- & 42 & 35 & 1.3 & 8.0 & 7.9 & -- & $<.02$ & $<5$ \\
\hline N10471 & $6-20-90$ & 12 & 46 & 44 & 41 & $<0.20$ & 7.6 & 10 & .08 & $<.02$ & $<5$ \\
\hline N10471 & $4-2-91$ & 12 & - & 33 & 34 & $<0.20$ & 7.2 & 17 & - & $<.02$ & $<5$ \\
\hline
\end{tabular}


Table 4. Inorganic-constituent analyses of ground-water samples from the New Cassel, N.Y., study area, 1990-91--continued

\begin{tabular}{|c|c|c|c|c|c|c|c|c|c|c|c|}
\hline $\begin{array}{c}\text { Well } \\
\text { number }\end{array}$ & Date & $\begin{array}{c}\text { Alka- } \\
\text { linity, } \\
\text { labora- } \\
\text { tory } \\
\text { (mg/L as } \\
\mathrm{CaCO}_{3} \text { ) }\end{array}$ & $\begin{array}{l}\text { Carbon } \\
\text { dloxide, } \\
\text { dis- } \\
\text { solved } \\
(\mathrm{mg} / \mathrm{L} \text { as } \\
\left.\mathrm{CO}_{2}\right)\end{array}$ & $\begin{array}{l}\text { Sulfate, } \\
\text { dis* } \\
\text { solved } \\
\text { (mg/Las } \\
\mathrm{SO}_{4} \text { ) }\end{array}$ & $\begin{array}{l}\text { Chlo- } \\
\text { ride, } \\
\text { dis- } \\
\text { solved } \\
\text { (mg/l as } \\
\text { Cl) }\end{array}$ & $\begin{array}{c}\text { Fluoride, } \\
\text { dis- } \\
\text { solved } \\
\text { (mg/L } \\
\text { as F) }\end{array}$ & $\begin{array}{l}\text { Silica, } \\
\text { dis- } \\
\text { solved } \\
\text { (mg/l as } \\
\left.\mathrm{SIO}_{2}\right)\end{array}$ & $\begin{array}{l}\text { Nitrogen, } \\
\text { nltrate, } \\
\text { dis- } \\
\text { solved } \\
\text { (mg/L as } \\
\text { N) }\end{array}$ & $\begin{array}{l}\text { Nitrogen, } \\
\text { nitrite, } \\
\text { dissolved } \\
\text { (mg/l as } \\
\text { N) }\end{array}$ & $\begin{array}{l}\text { Nitrogen, } \\
\text { ammonia, } \\
\text { dlssolved } \\
\text { (mg/L as } \\
\text { N) }\end{array}$ & $\begin{array}{c}\text { Arsenic, } \\
\text { dis- } \\
\text { solved } \\
\text { ( } \mu \text { g/l as } \\
\text { As) }\end{array}$ \\
\hline N10472 & $5-30-90$ & 3.0 & 37 & 11 & 35 & $<0.20$ & 7.6 & 6.8 & 0.01 & $<0.02$ & $<5$ \\
\hline N10473 & $5-30-90$ & 12 & 29 & 25 & 37 & $<0.20$ & 9.6 & 5.9 & $<.01$ & $<.02$ & $<5$ \\
\hline N10474 & $6-1-90$ & 17 & 41 & 26 & 66 & $<0.20$ & 7.8 & .57 & 1.8 & .37 & $<5$ \\
\hline N10474 & $1-28-91$ & 25 & -- & 33 & 90 & $<0.20$ & 7.9 & 2.6 & .24 & .37 & $<5$ \\
\hline N10475 & $6-4-90$ & 10 & 24 & 20 & 2.7 & $<0.20$ & 5.2 & $<.10$ & .04 & .04 & $<5$ \\
\hline N10476 & $5-22-90$ & 22 & 21 & 13 & 6.9 & $<0.20$ & 92 & 69 & .04 & $<.02$ & $<5$ \\
\hline $\mathrm{N} 10477$ & $5-31-90$ & -_ & 122 & 190 & 46 & 0.36 & 34 & 6.6 & .04 & .33 & $<5$ \\
\hline $\mathrm{N} 10477$ & $2-5-91$ & 2.0 & - & 89 & 80 & $<0.20$ & 25 & 6.4 & 10 & .63 & $<5$ \\
\hline N10478 & $5-31-90$ & 6.0 & 58 & 19 & 30 & $<0.20$ & 11 & 18 & .02 & .04 & $<5$ \\
\hline $\mathrm{N} 10478$ & $2,5,91$ & 6.0 & - & 21 & 33 & $<0.20$ & 11 & 23 & $<.01$ & $<.02$ & $<5$ \\
\hline N10479 & $5-23-90$ & 22 & 27 & 46 & 4.2 & $<0.20$ & 5.1 & 8.9 & $<.01$ & $<.02$ & $<5$ \\
\hline N10480 & $5-23-90$ & 6.0 & 46 & 30 & 22 & $<0.20$ & 12 & 11 & .02 & 1.2 & $<5$ \\
\hline N11841 & $4-23-91$ & 8.0 & -- & 17 & 21 & $<0.20$ & 8.1 & 1.5 & $<.01$ & $<.02$ & $<5$ \\
\hline N11842 & $4-23-91$ & 11 & -- & 23 & 110 & $<0.20$ & 9.2 & 4.7 & $<.01$ & $<.02$ & $<5$ \\
\hline N11843 & $5-23-91$ & 44 & -- & 52 & 12 & $<0.20$ & 6.4 & 1.3 & $<.01$ & $<.02$ & $<5$ \\
\hline N11843 & $5-23-91$ & 44 & - & 57 & 13 & $<0.20$ & 6.0 & 1.3 & $<.01$ & $<.02$ & $<5$ \\
\hline N11844 & $5-21-91$ & 11 & - & 23 & 25 & $<0.20$ & 14 & 5.6 & $<.01$ & $<, 02$ & $<5$ \\
\hline$N 11844$ & $5-21-91$ & 11 & - & 23 & 27 & $<0.20$ & 13 & 5.8 & $<.01$ & $<.02$ & $<5$ \\
\hline N11 1845 & $5-20-91$ & 3.0 & - & 18 & 15 & 0.29 & 19 & 26 & -- & .90 & $<5$ \\
\hline N11846 & $2-28-91$ & 16 & - & 24 & 38 & - & 5.7 & 2.8 & - & $<.02$ & $<5$ \\
\hline N11847 & $4-5-91$ & 78 & -- & 62 & 52 & $<0.20$ & 8.6 & $<.10$ & $<.01$ & .65 & $<5$ \\
\hline N1 1848 & $1-10-91$ & 24 & - & $<5.0$ & 33 & $<0.20$ & 3.6 & 1.2 & $<.01$ & $<.02$ & $<5$ \\
\hline N1 1849 & $2-5-91$ & 22 & -- & 42 & 43 & 0.28 & 4.9 & 2.5 & .19 & $<.02$ & $<5$ \\
\hline N11850 & $2-20-91$ & 18 & -- & 41 & 8.7 & $<0.20$ & 6.2 & 2.9 & -- & $<.02$ & $<5$ \\
\hline N1 1851 & $1-24-91$ & 17 & - & 41 & 95 & $<0.20$ & 5.6 & 6.1 & .03 & $<.02$ & $<5$ \\
\hline N11852 & $1-24-91$ & 21 & - & 30 & 24 & $<0.20$ & 17 & 4.0 & .02 & .44 & $<5$ \\
\hline N11853 & $2-20-91$ & 11 & - & 57 & 8.2 & $<0.20$ & 9.7 & 7.0 & - & $<.02$ & $<5$ \\
\hline N11854 & $2-21-91$ & 13 & - & 26 & 11 & $<0.20$ & 7.1 & 2.0 & - & $<0.02$ & $<5$ \\
\hline N1 1855 & $5-23-91$ & 23 & - & 26 & 70 & $<0.20$ & 11 & 8.6 & $<.01$ & .82 & $<5$ \\
\hline N11856 & $5-24-91$ & 18 & - & 66 & 30 & $<0.20$ & 13 & 6.3 & $\ldots$ & .06 & $<5$ \\
\hline N11856 & $5-24-91$ & 17 & - & 67 & 28 & $<0.20$ & 12 & 6.8 & -- & 0.06 & $<5$ \\
\hline N11857 & $3-12-91$ & 12 & -- & 22 & 22 & $<0.20$ & 10 & 6.3 & .01 & .02 & $<5$ \\
\hline N11858 & $5-21-91$ & 8.0 & - & 20 & 40 & $<0.20$ & 5.6 & 5.9 & $<.01$ & $<.02$ & $<5$ \\
\hline N11858 & $5-21-91$ & 5.0 & -- & 23 & 34 & $<0.20$ & 6.0 & 6.3 & .01 & $<.02$ & $<5$ \\
\hline N11859 & $1-10-91$ & 9.0 & -- & $<5.0$ & 17 & $<0.20$ & 6.7 & 1.6 & $<.01$ & $<.02$ & $<5$ \\
\hline N11860 & $1-28-91$ & 6.0 & - & 19 & 16 & $<0.20$ & 7.4 & 7.2 & .04 & .02 & $<5$ \\
\hline N11861 & 1-7-91 & 3.0 & - & 30 & 18 & 0.28 & 9.1 & 4.8 & $<.01$ & $<.02$ & $<5$ \\
\hline N11 1862 & 1-7-91 & 4.0 & -- & 42 & 18 & $<0.20$ & 11 & 4.5 & .01 & $<.02$ & $<5$ \\
\hline
\end{tabular}


Table 4. Inorganic-constituent analyses of ground-water samples from the New Cassel, N.Y., study area, 1990-91--continued

\begin{tabular}{|c|c|c|c|c|c|c|c|c|c|c|c|}
\hline $\begin{array}{c}\text { Well } \\
\text { number }\end{array}$ & Date & $\begin{array}{l}\text { Barlum, } \\
\text { dls- } \\
\text { solved } \\
\text { ( } \mu \text { g/l as } \\
\text { Ba) }\end{array}$ & $\begin{array}{l}\text { Cad- } \\
\text { mlum, } \\
\text { dls- } \\
\text { solved } \\
\text { ( } \mu \text { g/L as } \\
\text { Cd) }\end{array}$ & $\begin{array}{l}\text { Chro- } \\
\text { mlum, } \\
\text { dls- } \\
\text { solved } \\
\text { ( } \mu \text { g/L as } \\
\text { Cr) }\end{array}$ & $\begin{array}{l}\text { Copper, } \\
\text { dls- } \\
\text { solved } \\
(\mu g / L \text { as } \\
\text { Cu) }\end{array}$ & $\begin{array}{l}\text { Iron, } \\
\text { dis- } \\
\text { solved } \\
(\mu \mathrm{g} / \mathrm{L} \text { as } \\
\text { Fe) }\end{array}$ & $\begin{array}{l}\text { Lead, } \\
\text { dlis- } \\
\text { solved } \\
\text { ( } \mu \text { g/L as } \\
\text { Pb) }\end{array}$ & $\begin{array}{c}\text { Man- } \\
\text { ganese, } \\
\text { dle- } \\
\text { solved } \\
(\mu \mathrm{g} / \mathrm{L} \text { as } \\
\text { Mn) }\end{array}$ & $\begin{array}{c}\text { Selenlum, } \\
\text { dls- } \\
\text { solved } \\
(\mu g / L \text { as } \\
\text { Se) }\end{array}$ & $\begin{array}{l}\text { Sliver, } \\
\text { dls- } \\
\text { solved } \\
(\mu \mathrm{g} / \mathrm{L} \text { as } \\
\text { Ag) }\end{array}$ & $\begin{array}{l}\text { Methyiene } \\
\text { biue } \\
\text { active } \\
\text { substar ne } \\
\text { (mg/L) }\end{array}$ \\
\hline N5655 & $7-25-90$ & $<200$ & $<1.0$ & $<10$ & 360 & 50 & $<10$ & $<50$ & $<5$ & $<50$ & $<0.02$ \\
\hline N5655 & $3-26-91$ & $<200$ & $<1.0$ & $<10$ & 320 & $<50$ & $<10$ & $<50$ & $<5$ & $<50$ & $<0.02$ \\
\hline N6848 & $7-23-90$ & $<200$ & $<1.0$ & $<10$ & $<50$ & 220 & $<10$ & $<50$ & $<5$ & $<50$ & $<0.02$ \\
\hline N8497 & $7-25-90$ & $<200$ & $<1.0$ & $<1$ & $<50$ & 60 & $<10$ & $<50$ & $<5$ & $<50$ & $<0.02$ \\
\hline N8956 & $5-30-90$ & $<200$ & $<1.0$ & $<10$ & $<50$ & 50 & $<10$ & $<50$ & $<5$ & $<50$ & $<0.02$ \\
\hline N8956 & $4-4-91$ & $<200$ & $<1.0$ & $<10$ & $<50$ & $<50$ & $<10$ & $<50$ & $<5$ & $<50$ & $<0.02$ \\
\hline N8957 & $5-30-90$ & $<200$ & $<1.0$ & $<10$ & $<50$ & $<50$ & $<10$ & $<50$ & $<5$ & $<50$ & $<0.02$ \\
\hline N8957 & $4-4-91$ & $<200$ & $<1.0$ & $<10$ & $<50$ & $<50$ & $<10$ & $<50$ & $<5$ & $<50$ & $<0.02$ \\
\hline N8984 & $6-4-90$ & $<200$ & $<1.0$ & $<10$ & $<50$ & 960 & $<10$ & 60 & $<5$ & $<50$ & $<0.02$ \\
\hline N9234 & $8-14-90$ & $<200$ & $<1.0$ & $<10$ & $<50$ & $<50$ & $<10$ & $<50$ & $<5$ & $<50$ & $<0.02$ \\
\hline N9235 & $8-14-90$ & $<200$ & $<1.0$ & $<10$ & $<50$ & $<50$ & $<10$ & $<50$ & $<5$ & $<50$ & $<0.02$ \\
\hline N9236 & $7-18-90$ & $<200$ & $<1.0$ & $<10$ & $<50$ & $<50$ & $<10$ & $<50$ & $<5$ & $<50$ & $<0.02$ \\
\hline N9239 & $8-16-90$ & $<200$ & $<1.0$ & $<10$ & $<50$ & $<50$ & $<10$ & $<50$ & $<5$ & $<50$ & $<0.02$ \\
\hline N9239 & $8-16-90$ & $<200$ & $<1.0$ & $<10$ & $<50$ & 380 & $<10$ & $<50$ & $<5$ & $<50$ & $<0.02$ \\
\hline N9240 & $8-16-90$ & $<200$ & $<1.0$ & $<10$ & $<50$ & $<50$ & $<10$ & $<50$ & $<5$ & $<50$ & $<0.02$ \\
\hline N9241 & $8-16-90$ & $<200$ & $<1.0$ & $<10$ & $<50$ & $<50$ & $<10$ & 150 & $<5$ & $<50$ & $<0.02$ \\
\hline N9354 & $7.23-90$ & $<200$ & $<1.0$ & $<10$ & $<50$ & 2,900 & $<10$ & 750 & $<5$ & $<50$ & $<0.02$ \\
\hline N9354 & $7-23-90$ & $<200$ & $<1.0$ & $<10$ & $<50$ & 3,000 & $<10$ & 730 & $<5$ & $<50$ & $<0.02$ \\
\hline N9917 & $7-17-90$ & $<200$ & $<1.0$ & $<10$ & $<50$ & 5,100 & $<10$ & 2,200 & 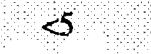 & $<50$ & $<0.02$ \\
\hline N9917 & $7-17-90$ & $<200$ & $<1.0$ & $<10$ & $<50$ & 4,900 & $<10$ & 2,300 & $<5$ & $<50$ & $<0.02$ \\
\hline N9938 & $6-13-90$ & $<200$ & $<1.0$ & $<10$ & $<50$ & 110 & $<10$ & 80 & $<5$ & $<50$ & $<0.02$ \\
\hline N9938 & 4-10-91 & $<200$ & $<1.0$ & $<10$ & $<50$ & $<50$ & $<10$ & 140 & $<5$ & $<50$ & - \\
\hline N9939 & $6-4-90$ & 300 & 2.0 & $<10$ & $<50$ & $<50$ & $<10$ & 1,100 & $<5$ & $<50$ & $<0.02$ \\
\hline N10292 & $7-18-90$ & $<200$ & $<1.0$ & $<10$ & $<50$ & 90 & $<10$ & 110 & $<5$ & $<50$ & $<0.02$ \\
\hline N10292 & $10-1-91$ & -- & -- & -- & -- & -- & -- & - & -- & -- & -- \\
\hline $\mathrm{N} 10292$ & $6-10-91$ & - & - & - & - & - & - & - & - & - & - \\
\hline N10318 & $6-7-90$ & 300 & $<1.0$ & $<10$ & $<50$ & $<50$ & $<10$ & 440 & $<5$ & $<50$ & $<0,02$ \\
\hline N10318 & $2-28-91$ & $<200$ & $<1.0$ & $<10$ & $<50$ & $<50$ & $<10$ & 1,500 & $<5$ & $<50$ & - \\
\hline N10319 & $6-18-90$ & $<200$ & $<1.0$ & $<10$ & $<50$ & $<50$ & $<10$ & 200 & $<5$ & $<50$ & $<0.02$ \\
\hline N10319 & $4-10-91$ & $<200$ & $<1.0$ & $<10$ & $<50$ & $<50$ & $<10$ & 690 & $<5$ & $<50$ & - \\
\hline N10320 & $6-12-90$ & $<200$ & 3.0 & $<10$ & $<50$ & $<50$ & $<10$ & 110 & $<5$ & $<50$ & $<0.02$ \\
\hline N10320 & $3-6-91$ & $<200$ & 2.0 & $<10$ & $<50$ & $<50$ & $<10$ & 110 & $<5$ & $<50$ & $<0.02$ \\
\hline N10321 & $6-13-90$ & $<200$ & $<1.0$ & $<10$ & $<50$ & 50 & $<10$ & 170 & $<5$ & $<50$ & $<0.02$ \\
\hline N10321 & $3-7-91$ & $<200$ & $<1.0$ & $<10$ & $<50$ & $<50$ & $<10$ & 140 & $<5$ & $<50$ & -- \\
\hline N10322 & $6-14-90$ & $<200$ & $<1.0$ & $<10$ & $<50$ & $<50$ & $<10$ & $<50$ & $<5$ & $<50$ & $<0.02$ \\
\hline $\mathrm{N} 10322$ & $3-6-91$ & $<200$ & $<1.0$ & $<10$ & $<50$ & 60 & $<10$ & $<50$ & $<5$ & $<50$ & $<0.02$ \\
\hline $\mathrm{N} 10322$ & $3-25-91$ & $<200$ & $<1.0$ & 140 & $<50$ & $<50$ & $<10$ & $<50$ & $<5$ & $<50$ & - \\
\hline $\mathrm{N} 10323$ & $6-20-90$ & $<200$ & $<1.0$ & 300 & $<50$ & 70 & $<10$ & 100 & $<5$ & $<50$ & $<0.02$ \\
\hline N10324 & $6-7-90$ & $<200$ & $<1.0$ & $<10$ & $<50$ & 50 & $<10$ & 340 & $<5$ & $<50$ & $<0.02$ \\
\hline N10324 & 4-3-91 & $<200$ & $<1.0$ & $<10$ & $<50$ & $<50$ & $<10$ & 310 & $<5$ & $<50$ & $<0.02$ \\
\hline
\end{tabular}


Table 4. Inorganic-constituent analyses of ground-water samples from the New Cassel, N.Y., study area, 1990-91--continued

\begin{tabular}{|c|c|c|c|c|c|c|c|c|c|c|c|}
\hline $\begin{array}{c}\text { Weli } \\
\text { number }\end{array}$ & Date & $\begin{array}{c}\text { Barium, } \\
\text { dls- } \\
\text { solved } \\
(\mu g / L \text { as } \\
\text { Ba) }\end{array}$ & $\begin{array}{l}\text { Cad- } \\
\text { mium, } \\
\text { dis- } \\
\text { soived } \\
(\mu \mathrm{g} / \mathrm{L} \text { as } \\
\text { Cd) }\end{array}$ & $\begin{array}{l}\text { Chro- } \\
\text { mium, } \\
\text { dis- } \\
\text { soived } \\
(\mu \mathrm{g} / \mathrm{L} \text { as } \\
\text { Cr) }\end{array}$ & $\begin{array}{c}\text { Copper, } \\
\text { dis- } \\
\text { soived } \\
(\mu \mathrm{g} / \mathrm{L} \text { as } \\
\mathrm{Cu})\end{array}$ & $\begin{array}{c}\text { iron, } \\
\text { dis- } \\
\text { solved } \\
(\mu \mathrm{g} / \mathrm{L} \text { as } \\
\mathrm{Fe})\end{array}$ & $\begin{array}{l}\text { Lead, } \\
\text { dls- } \\
\text { soived } \\
(\mu \mathrm{g} / \mathrm{L} \text { as } \\
\mathrm{Pb})\end{array}$ & $\begin{array}{c}\text { Man- } \\
\text { ganese, } \\
\text { dis- } \\
\text { soived } \\
(\mu g / L \text { as } \\
\text { Mn) }\end{array}$ & $\begin{array}{c}\text { Selenium, } \\
\text { dis- } \\
\text { soived } \\
(\mu \mathrm{g} / \mathrm{L} \text { as } \\
\text { Se })\end{array}$ & $\begin{array}{c}\text { Siiver, } \\
\text { dis- } \\
\text { solved } \\
(\mu \mathrm{g} / \mathrm{L} \text { as } \\
\mathrm{Ag})\end{array}$ & $\begin{array}{l}\text { Methylene } \\
\text { blue } \\
\text { active } \\
\text { substance } \\
\text { (mg/L) }\end{array}$ \\
\hline N10325 & $6-12-90$ & 200 & $<1.0$ & $<10$ & $<50$ & $<50$ & $<10$ & $<50$ & $<5$ & $<50$ & $<0.02$ \\
\hline $\mathrm{N} 10325$ & $4-8-91$ & $<200$ & $<1.0$ & $<10$ & $<50$ & $<50$ & $<10$ & $<50$ & $<5$ & $<50$ & $<0.02$ \\
\hline N10326 & $6-18-90$ & $<200$ & $<1.0$ & 30 & $<50$ & $<50$ & $<10$ & 900 & $<5$ & $<50$ & $<0.02$ \\
\hline N10326 & $4-2-91$ & $<200$ & $<1.0$ & 40 & 50 & 620 & $<10$ & 760 & $<5$ & $<50$ & $<0.02$ \\
\hline N10327 & $6-12-90$ & $<200$ & $<1.0$ & $<10$ & $<50$ & 60 & $<10$ & 1,300 & $<5$ & $<50$ & $<0.02$ \\
\hline $\mathrm{N} 10327$ & $3-26-91$ & $<200$ & $<1.0$ & $<10$ & $<50$ & $<50$ & $<10$ & 840 & $<5$ & $<50$ & $<0.02$ \\
\hline $\mathrm{N} 10328$ & $7-16-90$ & $<200$ & $<1.0$ & $<10$ & $<50$ & $<50$ & $<10$ & 70 & $<5$ & $<50$ & $<0.02$ \\
\hline N10328 & $3-13.91$ & $<200$ & $<1.0$ & $<10$ & $<50$ & $<50$ & $<10$ & 100 & $<$ & $<50$ & - \\
\hline N10329 & $5-24-90$ & $<200$ & $<1.0$ & $<10$ & $<50$ & $<50$ & $<10$ & $<50$ & $<5$ & $<50$ & $<0.02$ \\
\hline N10329 & $2-21-91$ & $<200$ & $<1.0$ & $<10$ & $<50$ & $<50$ & $<10$ & 80 & $<5$ & $<50$ & $<0.02$ \\
\hline N10458 & $6-18-90$ & $<200$ & $<1.0$ & $<10$ & $<50$ & $<50$ & 20 & 100 & $<5$ & $<50$ & $<0.02$ \\
\hline $\mathrm{N} 10458$ & $3-29-91$ & $<200$ & $<1.0$ & $<10$ & $<50$ & $<50$ & $<10$ & 140 & $<5$ & $<50$ & $<0.02$ \\
\hline N10459 & $7-25-90$ & $<200$ & $<1.0$ & $<10$ & $<50$ & $<50$ & $<10$ & 400 & $<5$ & $<50$ & $<0.02$ \\
\hline N10459 & $3-26-91$ & $<200$ & $<1.0$ & $<10$ & $<50$ & $<50$ & $<10$ & 470 & $<5$ & $<50$ & $<0.02$ \\
\hline N10460 & $6-5-90$ & $<200$ & $<1.0$ & $<10$ & $<50$ & $<50$ & $<10$ & 190 & $<5$ & $<50$ & $<0.02$ \\
\hline N10460 & $3-25-91$ & $<200$ & $<1.0$ & $<10$ & $<50$ & $<50$ & $<10$ & 220 & $<5$ & $<50$ & - \\
\hline Nio461 & $6-5-90$ & $<200$ & $<1.0$ & $<10$ & $<50$ & $<50$ & $<10$ & 1,200 & $<5$ & $<50$ & $<0.02$ \\
\hline N10461 & $3-5-91$ & $<200$ & $<1.0$ & $<10$ & $<50$ & 90 & $<10$ & 1,400 & $<5$ & $<50$ & $<0.02$ \\
\hline $\mathrm{N} 10462$ & $6-5-90$ & $<200$ & $<1.0$ & $<10$ & $<50$ & $<50$ & $<10$ & $<10$ & $<5$ & $<50$ & $<0.02$ \\
\hline $\mathrm{N} 10462$ & 3-7-91 & $<200$ & $<1.0$ & $<10$ & $<50$ & $<50$ & $<10$ & $<50$ & $<5$ & $<50$ & - \\
\hline N10463 & $6-13-90$ & $<200$ & $<1.0$ & $<10$ & $<50$ & $<50$ & $<10$ & 60 & $<5$ & $<50$ & $<0.02$ \\
\hline N10463 & $2-28-91$ & $<200$ & $<1.0$ & $<10$ & 50 & 70 & $<10$ & 50 & $<5$ & $<50$ & -- \\
\hline N10464 & $6-7-90$ & $<200$ & $<1.0$ & $<10$ & $<50$ & 570 & $<10$ & $<50$ & $<5$ & $<50$ & $<0.02$ \\
\hline N10464 & $3-12-91$ & $<200$ & $<1.0$ & $<10$ & $<50$ & 160 & $<10$ & $<50$ & $<5$ & $<50$ & $<0.02$ \\
\hline N10465 & $6-12-90$ & $<200$ & $<1.0$ & $<10$ & $<50$ & $<50$ & $<10$ & 110 & $<5$ & $<50$ & $<0.02$ \\
\hline N10465 & $3-13-91$ & $<200$ & $<1.0$ & $<10$ & $<50$ & $<50$ & $<10$ & 90 & $<5$ & $<50$ & - \\
\hline $\mathrm{N} 10466$ & $6-490$ & 300 & $<1.0$ & $<10$ & $<50$ & $<50$ & $<10$ & $<50$ & $<5$ & $<50$ & $<0.02$ \\
\hline N10466 & $64-90$ & 300 & $<1.0$ & $<10$ & $<50$ & $<50$ & $<10$ & $<50$ & $<5$ & $<50$ & $<0.02$ \\
\hline N10466 & 1-29-91 & 400 & $<1.0$ & $<10$ & $<50$ & $<50$ & $<10$ & $<50$ & $<5$ & $<50$ & - \\
\hline $\mathrm{N} 10467$ & $6-13-90$ & $<200$ & $<1.0$ & $<10$ & $<50$ & $<50$ & $<10$ & 300 & $<$ & $<50$ & $<0.02$ \\
\hline N10467 & $4-8-91$ & $<200$ & $<1.0$ & $<10$ & $<50$ & $<50$ & $<10$ & 170 & $<5$ & $<50$ & $<0.02$ \\
\hline N10468 & $7-19-90$ & $<200$ & $<1.0$ & $<10$ & $<50$ & 60 & $<10$ & 350 & $<5$ & $<50$ & $<0.02$ \\
\hline N10468 & $3-6-91$ & $<200$ & $<1.0$ & $<10$ & $<50$ & $<50$ & $<10$ & 260 & $<5$ & $<50$ & $<0.02$ \\
\hline N10469 & $6-14-90$ & $<200$ & 1.0 & $<10$ & $<50$ & $<50$ & $<10$ & $<50$ & $<5$ & $<50$ & $<0.02$ \\
\hline N10469 & $3-1-91$ & $<200$ & $<1.0$ & $<10$ & $<50$ & $<50$ & $<10$ & $<50$ & $<5$ & $<50$ & - \\
\hline $\mathrm{N} 10470$ & $6-20-90$ & $<200$ & $<1.0$ & $<10$ & $<50$ & $<50$ & $<10$ & $<50$ & $<5$ & $<50$ & $<0.02$ \\
\hline $\mathrm{N} 10470$ & $7-17-90$ & $<200$ & $<1.0$ & $<10$ & $<50$ & $<50$ & $<10$ & 140 & $<5$ & $<50$ & $<0.02$ \\
\hline $\mathrm{N} 10470$ & 4-3-91 & $<200$ & $<1.0$ & $<10$ & $<50$ & $<50$ & $<10$ & 580 & $<5$ & $<50$ & $<0.02$ \\
\hline $\mathrm{N} 10471$ & $6-20-90$ & 200 & $<1.0$ & $<10$ & $<50$ & $<50$ & $<10$ & 700 & $<5$ & $<50$ & $<0.02$ \\
\hline N10471 & $4-2-91$ & 300 & $<1.0$ & $<10$ & $<50$ & $<50$ & $<10$ & 500 & $<5$ & $<50$ & $<0.02$ \\
\hline
\end{tabular}


Table 4. Inorganic-constituent analyses of ground-water samples from the New Cassel, N.Y., study area, 1990-91--continued

\begin{tabular}{|c|c|c|c|c|c|c|c|c|c|c|c|}
\hline $\begin{array}{c}\text { Weil } \\
\text { number }\end{array}$ & Date & $\begin{array}{c}\text { Barium, } \\
\text { dls- } \\
\text { soived } \\
(\mu \mathrm{g} / \mathrm{L} \text { as } \\
\text { Ba) }\end{array}$ & $\begin{array}{l}\text { Cad- } \\
\text { mlum, } \\
\text { dis- } \\
\text { soived } \\
\text { ( } \mu \text { g'L as } \\
\text { Cd })\end{array}$ & $\begin{array}{l}\text { Chro- } \\
\text { mlum, } \\
\text { dls- } \\
\text { soived } \\
\text { ( } \mu \text { g/L as } \\
\text { Cr) }\end{array}$ & $\begin{array}{c}\text { Copper, } \\
\text { dis- } \\
\text { soived } \\
(\mu g / L \text { as } \\
\text { Cu })\end{array}$ & $\begin{array}{c}\text { iron, } \\
\text { dis- } \\
\text { solved } \\
(\mu \mathrm{g} / \mathrm{L} \text { as } \\
\text { Fe })\end{array}$ & $\begin{array}{l}\text { Lead, } \\
\text { dis- } \\
\text { soived } \\
(\mu \mathrm{g} / \mathrm{L} \text { as } \\
\mathrm{Pb})\end{array}$ & $\begin{array}{c}\text { Man- } \\
\text { ganese, } \\
\text { dis- } \\
\text { soived } \\
(\mu \mathrm{g} / \mathrm{L} \text { as } \\
\text { Mn) }\end{array}$ & $\begin{array}{l}\text { Selenium, } \\
\text { dis- } \\
\text { soived } \\
(\mu g / L \text { as } \\
\text { Se) }\end{array}$ & $\begin{array}{c}\text { Silver, } \\
\text { dis- } \\
\text { solved } \\
(\mu \mathrm{g} / \mathrm{L} \text { as } \\
\text { Ag) }\end{array}$ & $\begin{array}{l}\text { Methyiene } \\
\text { blue } \\
\text { active } \\
\text { substanne } \\
\text { (mg/L) }\end{array}$ \\
\hline N10472 & $5-30-90$ & $<200$ & $<1.0$ & $<10$ & $<50$ & 160 & $<10$ & 160 & $<5$ & $<50$ & $<0.02$ \\
\hline N10473 & $5-30-90$ & $<200$ & $<1.0$ & $<10$ & $<50$ & $<50$ & $<10$ & 60 & $<5$ & $<50$ & $<0.02$ \\
\hline N10474 & $6-1-90$ & -- & $<1.0$ & $<10$ & $<50$ & $<50$ & $<10$ & 1,600 & $<5$ & $<50$ & $<0.02$ \\
\hline N10474 & $1-28-91$ & $<200$ & $<1.0$ & $<10$ & $<50$ & $<50$ & $<10$ & 1,900 & $<5$ & $<50$ & -- \\
\hline N10475 & $6-4-90$ & $<200$ & 3.0 & $<10$ & 100 & $<50$ & $<10$ & 1,000 & $<5$ & $<50$ & $<0.02$ \\
\hline N10476 & $5-22-90$ & $<200$ & $<1.0$ & $<10$ & $<50$ & 2,100 & $<10$ & 530 & $<5$ & $<50$ & $<0.02$ \\
\hline N10477 & $5-31-90$ & $<200$ & $<1.0$ & $<10$ & $<50$ & $<50$ & $<10$ & 3,200 & $<5$ & $<50$ & 0.05 \\
\hline N10477 & $2-5-91$ & $<200$ & $<1.0$ & $<10$ & $<50$ & $<50$ & $<10$ & 2,100 & $<5$ & $<50$ & 0.27 \\
\hline N10478 & $5-31-90$ & $<200$ & $<1.0$ & $<10$ & $<50$ & $<50$ & $<10$ & 70 & $<5$ & $<50$ & $<0.02$ \\
\hline $\mathrm{N} 10478$ & $2-5-91$ & $<200$ & $<1.0$ & $<10$ & $<50$ & $<50$ & $<10$ & 60 & $<5$ & $<50$ & $<0.02$ \\
\hline N10479 & $5-23-90$ & $<200$ & $<1.0$ & $<10$ & $<50$ & $<50$ & $<10$ & $<50$ & $<5$ & $<50$ & $<0.02$ \\
\hline N10480 & $5-23-90$ & $<200$ & $<1.0$ & $<10$ & $<50$ & $<50$ & $<10$ & 550 & $<5$ & $<50$ & $<0.02$ \\
\hline N1 1841 & $4-23-91$ & $<200$ & $<1.0$ & $<10$ & $<50$ & $<50$ & $<10$ & 250 & $<5$ & $<50$ & -- \\
\hline N11842 & 4-23-91 & $<200$ & $<1.0$ & $<10$ & $<50$ & $<50$ & $<10$ & 150 & $<5$ & $<50$ & -- \\
\hline N1 1843 & 5-23-91 & $<200$ & $<1.0$ & $<10$ & $<50$ & $<50$ & $<10$ & $<50$ & $<5$ & $<50$ & -- \\
\hline $\mathrm{N} 11843$ & $5-23-91$ & $<200$ & $<1.0$ & $<10$ & $<50$ & $<50$ & $<10$ & $<50$ & $<5$ & $<50$ & - \\
\hline N11844 & $5-21-91$ & $<200$ & $<1.0$ & $<10$ & $<50$ & 210 & $<10$ & 1,100 & $<5$ & $<50$ & - \\
\hline $\mathrm{N} 11844$ & $5-21-91$ & $<200$ & $<1.0$ & $<10$ & $<50$ & $<50$ & $<10$ & 1,100 & $<5$ & $<50$ & - \\
\hline N11845 & $5-20-91$ & 200 & 9.0 & $<10$ & $<50$ & $<50$ & $<10$ & 1,500 & $<5$ & $<50$ & - \\
\hline N11846 & $2 \cdot 28-91$ & $<200$ & $<10$ & $<10$ & $<50$ & $<50$ & $<10$ & $<50$ & $<5$ & $<50$ & - \\
\hline N1 1847 & $4-5-91$ & $<200$ & $<1.0$ & $<10$ & $<50$ & 110 & $<10$ & 4,700 & $<5$ & $<50$ & $<0.02$ \\
\hline N11848 & $1-10-91$ & $<200$ & $<1.0$ & $<10$ & $<50$ & $<50$ & $<10$ & 50 & $<5$ & $<50$ & $<0.02$ \\
\hline N11849 & $2-5-91$ & $<200$ & $<1.0$ & $<10$ & $<50$ & $<50$ & $<10$ & $<50$ & $<5$ & $<50$ & $<0.02$ \\
\hline N11850 & $2-20-91$ & $<200$ & $<1.0$ & $<10$ & $<50$ & $<50$ & $<10$ & $<50$ & $<5$ & $<50$ & $<0.02$ \\
\hline N11851 & $1-24-91$ & $<200$ & 3.0 & $<10$ & $<50$ & $<50$ & $<10$ & 50 & $<5$ & $<50$ & $<0.02$ \\
\hline N11852 & $1-24-91$ & $<200$ & $<1.0$ & $<10$ & $<50$ & $<50$ & $<10$ & 990 & $<5$ & $<50$ & $<0.02$ \\
\hline N11853 & $2-20-91$ & $<200$ & $<1.0$ & $<10$ & $<50$ & $<50$ & $<10$ & 1,100 & $<5$ & $<50$ & $<0.02$ \\
\hline N11854 & $2-21-91$ & $<200$ & $<1.0$ & 50 & $<50$ & $<50$ & $<10$ & 50 & $<5$ & $<50$ & $<0.02$ \\
\hline N11855 & $5-23-91$ & $<200$ & $<1.0$ & $<10$ & $<50$ & $<50$ & $<10$ & 990 & $<5$ & $<50$ & - \\
\hline N11856 & $5-24-91$ & $<200$ & $<1.0$ & $<10$ & $<50$ & $<50$ & $<10$ & 4,600 & $<5$ & $<50$ & - \\
\hline N11856 & $5-24-91$ & $<200$ & $<1.0$ & $<10$ & $<50$ & $<50$ & $<10$ & 4,600 & $<5$ & $<50$ & -- \\
\hline N1 1857 & $3-12-91$ & $<200$ & $<1.0$ & $<10$ & $<50$ & $<50$ & $<10$ & 80 & $<5$ & $<50$ & $<0.02$ \\
\hline N11858 & $5-21-91$ & $<200$ & $<1.0$ & $<10$ & $<50$ & $<50$ & $<10$ & $<50$ & $<5$ & $<50$ & -- \\
\hline N11858 & $5-21-91$ & $<200$ & $<1.0$ & $<10$ & $<50$ & $<50$ & $<10$ & $<50$ & $<5$ & $<50$ & -- \\
\hline N11859 & $1-10-91$ & $<200$ & $<1.0$ & $<10$ & $<50$ & $<50$ & $<10$ & 60 & $<5$ & $<50$ & $<0.02$ \\
\hline N11 1860 & $1-28-91$ & $<200$ & 1.0 & $<10$ & $<0$ & $<50$ & $<10$ & 70 & $<5$ & $<50$ & - \\
\hline N11861 & $1-7-91$ & $<200$ & $<1.0$ & $<10$ & $<50$ & $<50$ & $<10$ & 170 & $<5$ & $<50$ & $<0.02$ \\
\hline $\mathrm{N} 11862$ & $1-7.91$ & $<200$ & $<1,0$ & $<10$ & $<50$ & $<50$ & $<10$ & 240 & $<5$ & $<50$ & $<0.02$ \\
\hline
\end{tabular}

